\title{
Geochemistry and Mineralogy of Soils Collected in the Lower Rio Grande Valley, Texas
}

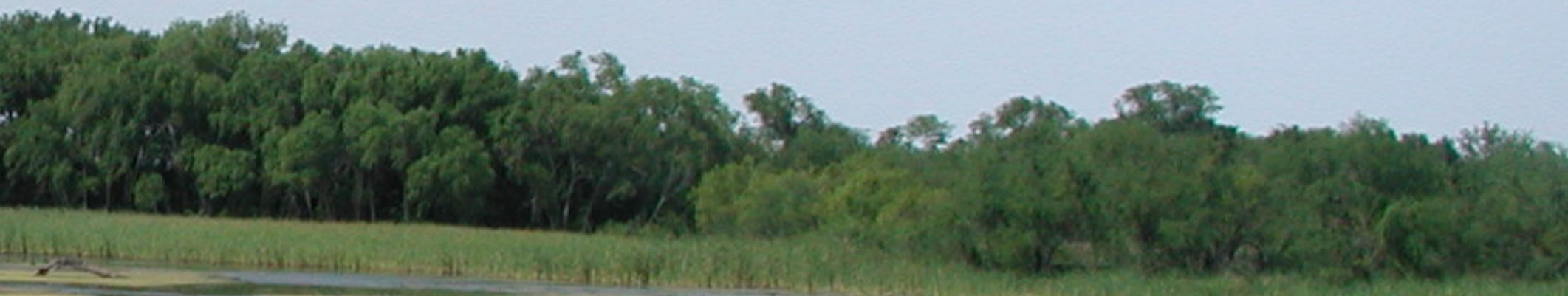

Open-File Report 2019-1010 
Cover. Photograph of the lower Rio Grande valley, spring 2003. Photograph by Helen A. Whitney, U.S. Geological Survey. 


\section{Geochemistry and Mineralogy of Soils Collected in the Lower Rio Grande Valley, Texas}

By Helen A. Whitney, Federico Solano, and Bernard E. Hubbard

Open-File Report 2019-1010 


\title{
U.S. Department of the Interior \\ DAVID BERNHARDT, Secretary
}

\author{
U.S. Geological Survey \\ James F. Reilly II, Director
}

U.S. Geological Survey, Reston, Virginia: 2019

For more information on the USGS - the Federal source for science about the Earth, its natural and living resources, natural hazards, and the environment-visit https://www.usgs.gov or call 1-888-ASK-USGS.

For an overview of USGS information products, including maps, imagery, and publications,

visit https://store.usgs.gov.

Any use of trade, firm, or product names is for descriptive purposes only and does not imply endorsement by the U.S. Government.

Although this information product, for the most part, is in the public domain, it also may contain copyrighted materials as noted in the text. Permission to reproduce copyrighted items must be secured from the copyright owner.

Suggested citation:

Whitney, H.A., Solano, F., and Hubbard, B.E., 2019, Geochemistry and mineralogy of soils collected in the lower Rio Grande valley, Texas: U.S. Geological Survey Open-File Report 2019-1010, 92 p., https://doi.org/10.3133/ ofr20191010.

ISSN 2331-1258 (online) 


\section{Contents}

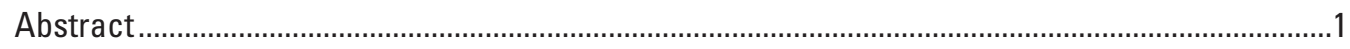

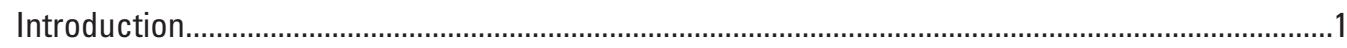

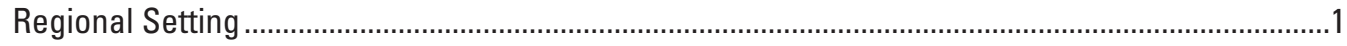

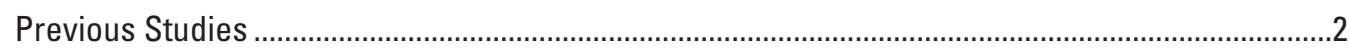

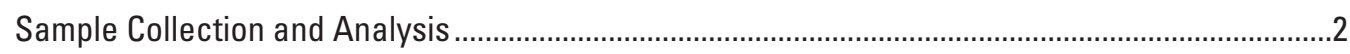

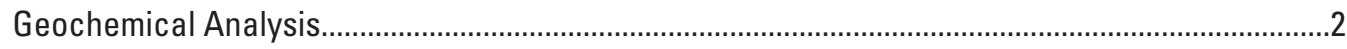

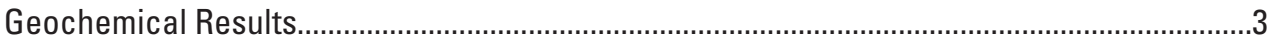

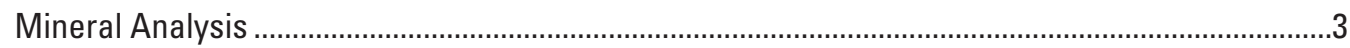

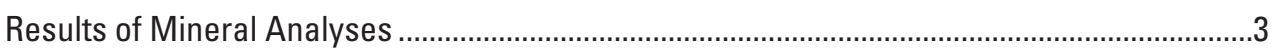

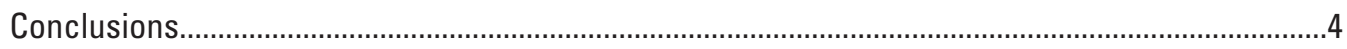

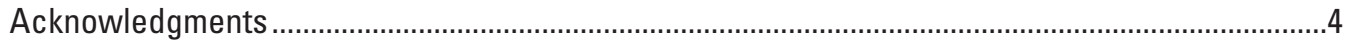

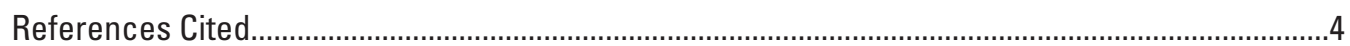




\section{Figures}

1. Map showing study area in the lower Rio Grande valley, Texas.

2. Geologic map of the lower Rio Grande valley, Texas showing the location of soil sample sites

3. Graphs showing univariate statistics for each of the seven major mineral groups identified in the soils from the lower Rio Grande valley.

4. Map showing quartz content in soils of the lower Rio Grande valley, Texas, using an inverse distance-weighted model grid

5. Map showing carbonate mineral content in soils of the lower Rio Grande valley, Texas, by percentile, using an inverse distance-weighted grid

6. Map showing potassium feldspar content in soils of the lower Rio Grande valley, Texas, by percentile, using an inverse distance-weighted grid

7. Map showing plagioclase content in soils of the lower Rio Grande valley, Texas, by percentile, using an inverse distance-weighted grid

8. Map showing muscovite content in soils of the lower Rio Grande valley, Texas, by percentile, using an inverse distance-weighted grid

9. Map showing kaolinite content in soils of the lower Rio Grande valley, Texas, by percentile, using an inverse distance-weighted grid

10. Map showing smectite content in soils of the lower Rio Grande valley, Texas, by percentile, using an inverse distance-weighted grid

\section{Tables}

[All tables also available online at https://doi.org/10.3133/ofr20191010]

1. Geochemical analyses of soil samples collected in $2003-04$, by element and method of analysis, lower Rio Grande valley, Texas

2. Geochemical analyses of soil samples collected in 2007 , by element and method of analysis, lower Rio Grande valley, Texas.

3. Univariate statistics and percentiles of analytical results for soil samples collected in 2003 and 2004, lower Rio Grande valley, Texas.

4. Univariate statistics and percentiles of analytical results for soil samples collected in 2007, lower Rio Grande valley, Texas.

5. Mineralogy of all soil samples collected in 2003, 2004, and 2007, lower Rio Grande valley, Texas

6. Summary statistics of mineral content of soils by geologic formation as determined by $\mathrm{x}$-ray diffraction 


\section{Conversion Factors}

U.S. customary units to International System of Units

\begin{tabular}{|c|c|c|}
\hline Multiply & By & To obtain \\
\hline \multicolumn{3}{|c|}{ Length } \\
\hline inch (in.) & 2.54 & centimeter $(\mathrm{cm})$ \\
\hline inch (in.) & 25.4 & millimeter (mm) \\
\hline foot $(\mathrm{ft})$ & 0.3048 & meter $(\mathrm{m})$ \\
\hline mile (mi) & 1.609 & kilometer (km) \\
\hline
\end{tabular}





\title{
Geochemistry and Mineralogy of Soils Collected in the Lower Rio Grande Valley, Texas
}

\author{
By Helen A. Whitney, Federico Solano, and Bernard E. Hubbard
}

\begin{abstract}
Presented in this report are the chemical and mineralogical results of a soil study conducted in the lower Rio Grande valley, Texas. Samples were collected from soils formed on Holocene alluvial flood-plain and distributary channel deposits of the Rio Grande, flood plain and meander-belt deposits of the Pliocene Goliad Formation, and the Pleistocene Lissie and Beaumont Formations. The lower Rio Grande valley is located on the old distributary delta of the Rio Grande. The watersheds on the U.S. side of the delta no longer drain into the Rio Grande but are part of a complex system of irrigation channels and wastewater drains that flow into the lower Laguna Madre. The results of the study have been used to map concealed geologic units and identify potential mosquito breeding habitat.
\end{abstract}

\section{Introduction}

The lower Rio Grande valley (LRGV) refers to a four-county region (Hidalgo, Cameron, Starr, and Willacy) in Texas bounded by the Rio Grande river (also known as the Rio Bravo) to the south. The LRGV stretches from the Falcon Reservoir eastward to the Laguna Madre and the Gulf of Mexico (fig. 1; figs. 1-10 follow References Cited). This area was selected for study by the U.S. Geological Survey (USGS) Border Environmental Health Initiative (BEHI) because the area is experiencing rapid economic and population growth, which may have adverse effects on the health of the environment, wildlife, and human inhabitants. Much of this growth is in response to the favorable economic conditions generated by the North American Free Trade Agreement Implementation Act of 1993 (Public Law 103-182, 107 Stat. 2057).

Agriculture dominates the land use and the economy of the region; however, manufacturing, oil and gas production, and tourism are also major contributors to the economy. The population in the LRGV grew from 978,369 in the year 2000 (U.S. Census Bureau, 2000) to an estimated 1,368,269 in the year 2012 (Texas Department of State Health Services, 2012).

The upper centimeter $(\mathrm{cm})$ interval of soil was selected because it is considered by the human health community as a critical zone- the zone where humans and animals may come in contact with toxins residing in soils through dermal, inhalation, and ingestion pathways (Brantley and others, 2007; Smith and others, 2009). This same soil interval is also most likely to be transported by wind or water from fields as sediment into the drainage canals and streams in the lower Rio Grande valley area.

\section{Regional Setting}

The LRGV is part of the West Gulf Coastal Plain, a belt of Late Cretaceous to Holocene marine sedimentary rocks that gently slopes toward the Gulf of Mexico. The climate is subtropical; high temperatures range from the mid 90s in degrees Fahrenheit $\left({ }^{\circ} \mathrm{F}\right.$ ) in Brownsville and low 100s (in ${ }^{\circ} \mathrm{F}$ ) near the Falcon Dam during the summer months to the mid 50s ${ }^{\circ} \mathrm{F}$ during winter months (Menne and others, 2012). The prevailing wind direction is from the southeast, except in the winter months when winds from the northwest prevail (National Oceanic and Atmospheric Administration, 2014). The average annual precipitation from 2010 to 2014 was 26 inches in Brownsville and 21 inches near the Falcon Dam (National Oceanic and Atmospheric Administration, 2014). The coastal areas are more humid and lush compared to the semi-arid climate of the Falcon Reservoir area, which is farther inland (fig. 1).

The oldest rock units in the study area are located to the north and west and the youngest are located along the present course of the Rio Grande and along the eastern coastline of the Laguna Madre (fig. 2). The oldest units are the fluvial sands of the Pliocene Goliad Formation, followed by the Pleistocene fluvial and meander belt sands of the Lissie Formation and the fluvial and deltaic deposits of the Beaumont Formation (Galloway and others, 2000). Organic-rich Holocene sediments consisting of silty-sandy alluvium, muddy flood-plain alluvium, and silty and sandy coastal deltaic deposits (Page and others, 2005) are located nearest to the Rio Grande and along the coastline of the Laguna Madre. 


\section{Previous Studies}

Notable scientific studies of the area began in the early 1900s with the publication of soil surveys of the Brownsville area by Mangum and Lee (1907). In their report, they describe the region prior to the development of the Falcon Dam and the extensive irrigation network that now restricts the natural flow of the Rio Grande. Subsequently, soil surveys for Starr (Thompson and others, 1972), Cameron (Williams and others, 1977), Hidalgo (Jacobs, 1981), and Willacy (Turner, 1982) Counties were completed. Brown and others (1980) constructed detailed environmental geologic maps of the Brownsville-Harlingen coastal area as part of a larger study of the natural resources of the Texas coastal zone. The maps and discussions provided helpful background information on the geologic history, coastal processes, and resource development of the area.

The Border Environmental Health Initiative began in 2003 as a USGS-sponsored collaborative study involving many scientists from the United States and Mexico - including biologists, hydrologists, geochemists, geologists, and geographers. The primary goal of the project was to collect and integrate data useful for examining the environmental health of the binational border region and to release these integrated products to other researchers working in the area (Buckler and Strom, 2004; Papoulias and others, 2006; Parcher, 2008). This study reports the geochemistry and mineralogy of the surficial soil layer, and is one of many studies completed in the Basin 8 subregion (Papoulias and others, 2006).

A modified version of the geologic map compiled by Page and others (2005) was used as the base map in the following discussions of the geochemical and statistical results. Page and others (2005) used the digital geologic map of Texas (Bureau of Economic Geology, 1976) and map data provided by the Instituto Nacional de Estadística y Geografía (INEGI) in the compilation of their binational geologic map of southern Texas, United States, and Tamaulipas, Mexico, for the LRGV. The base map used in this report has been further modified to show only the U.S. side of the Rio Grande valley.

Preliminary results from this study were presented by Duval (2005), Folger and others (2006), Hubbard and others (2006), Page and others (2006), Merrill and others (2006), and Hubbard and others (2010).

\section{Sample Collection and Analysis}

In the early summer months of 2003, 2004, and 2007, 210 soil samples were collected from vacant lots, fallow agricultural fields, pastures, natural grasslands, and undeveloped lands on a scale of one sample per 4 square miles. Soil samples were collected from the upper $0-5 \mathrm{~cm}$ portion of the soil profile at 210 sites using stainless steel shovels, then double bagged to prevent contamination of samples while in transport. All soils were prepared in USGS laboratories where they were disaggregated by a soil juicer and sieved to a $<2$-millimeter $(\mathrm{mm})$ grain size $(<10$-mesh) fraction. A split of the $<2$-mm soil sample was ground to $<150$-micrometer $(\mu \mathrm{m})$ grain-size $(<100$-mesh) prior to geochemical analysis. The geochemical samples were analyzed by USGS laboratories in Denver, Colo., and by contract laboratories in Canada. A split (about 5 grams) of the $<2$-mm soil sample was micronized to $<150-\mu \mathrm{m}$ grain-size together with 10 weight percent zincite $(\mathrm{ZnO})$ as an internal mineral standard prior to analysis using an x-ray diffractometer (XRD). Mineral identification and quantification were completed at the USGS laboratories in Reston, Va.

\section{Geochemical Analysis}

Analytical results are compiled into two tables; table 1 (tables 1-6 follow References Cited) contains the results for samples collected in 2003 and 2004, and table 2 contains the results from samples collected in 2007. Forty-two-element geochemistry (ICPAES-MS 42; Briggs and Meier, 2002) analyses were performed using inductively coupled plasma-atomic emission spectrometry (ICP-AES) and inductively coupled plasma-mass spectrometry (ICP-MS). Samples were digested in a multi-acid procedure prior to analysis by ICP-AES and ICP-MS methods. Analytical results are shown in tables 1 and 2, and limits of detection are listed in table 3. Elements analyzed by this combination ICP-MS and ICP-AES method have a prefix of "ICPMSAES" before the element name; for example, ICPMS-AES_Mg. Note that there was a change in the detection limit for cesium (Cs) from 0.05 parts per million (ppm) to 5 ppm for the samples analyzed in 2007 compared to those analyzed in 2003 and 2004.

Sixteen major, minor, and trace elements (ICPAES_16, method 17 in U.S. Geological Survey [2011]) were measured by ICP-AES. Samples were fused with lithium metaborate in a graphite crucible and then aspirated into the spectrometer. These results are listed in table 1 and the limits of detection are listed in table 3.

Ten major elements were determined by wavelength dispersive $\mathrm{x}$-ray fluorescence spectrometry (WDXRF; Taggart and Siems, 2002). Samples were fused with a flux containing equal parts of lithium metaborate and lithium tetraborate prior to irradiation and measurement of $\mathrm{x}$-ray photons by the spectrometer. Elements measured by this method use the acronym XRF in table 2. The limits of detection are listed in table 4. 
Samples collected in 2007 were digested in a multi-acid procedure to form arsenic or selenium hydrides that then were heated and analyzed by atomic absorption spectrometry (AAS; Hageman and others, 2002). This method can measure small concentrations of these elements in various sample media. The optimum concentration range for measurement is $0.1-4 \mathrm{ppm}$ for selenium and $0.2-20 \mathrm{ppm}$ for arsenic.

Mercury (Hg) was only measured in samples collected in 2007. The samples were first digested using a multi-acid digestion procedure, then measured by continuous-flow vapor-atomic absorption spectrometry (CVAAS; Brown and others, 2002). The results for mercury are listed in table 2 and the limits of detection are listed in table 4.

\section{Geochemical Results}

Statistical summaries of geochemical analytical results are shown in tables 3 and 4 . The summary tables list univariate statistics calculated on all analyses. Percentiles were calculated on all the analyzed samples including those with concentrations below the lower limit of detection. These tables also list the maximum and minimum concentration measured for each element by method. Statistical tests on chemical and mineral results were run using JMP ${ }^{\mathrm{TM}}$ (ver. 10) software (SAS Institute Inc.; www.sas. com).

\section{Mineral Analysis}

Samples were analyzed for mineralogy using an XRD and quantified (table 5) using the Rietveld refinement of X'Pert Highscore Plus ${ }^{\mathrm{TM}}$ version 2.25e software (Malvern Panalytical; www.malvernpanalytical.com). The sum of the refined phases has been normalized to 100 percent and excludes the amorphous phase. The term "amorphous phase" refers to the noncrystalline phases present in soils that could not be identified during the XRD analysis of the soil.

\section{Results of Mineral Analyses}

A statistical analysis of the mineralogy was conducted on the seven most common minerals or mineral groups identified within the soil samples, which were quartz, muscovite, kaolinite, smectite (dominantly montmorillonite), total plagioclase, total K-feldspar (potassium-bearing), and total carbonate group. Carbonate group minerals include calcite, dolomite, siderite, and aragonite. Summary statistics are listed in table 6. Figure $3 A-G$ shows the graphical results of the statistical tests. Box plots show the relative distribution of each mineral group by geologic unit (Page and others, 2005). One-way analysis of variance and a Tukey-Kramer test was performed for each mineral or mineral group. The Tukey-Kramer test compared the means of the mineral data for each geologic unit to determine if there were significant differences in the mineral concentrations between the units. The test results are illustrated using circle symbols that plot about the sample mean value. Circles that nest within or very near other circles have similar sample means. Histograms of the mineralogy, illustrating the relative proportion of each mineral group by geologic unit, show the strong influence of quartz and calcium carbonate in interpreting the geochemistry of the area. Histograms of the seven dominant minerals (or mineral groups) are displayed for the Goliad (G), Lissie (L), Beaumont (B), and Holocene (H) geologic units described by Page and others (2005).

Thematic maps of mineral concentrations were created to convey the spatial relations between mineral concentrations and the geology and geography of the region. Mineral concentrations were gridded using an inverse distance weighted algorithm of Geosoft Oasis Montaj ${ }^{\mathrm{TM}}$. The quartz distribution (fig. 4) shows high concentrations in soils overlying the sandstone of the Goliad Formation (Tg) and sand-rich-fluvial channel deposits of the Beaumont Formation (Qb). The high quartz concentrations seen in the lower part of the Beaumont Formation $(\mathrm{Qb})$ soils and the central portion of the Holocene soils (Qaf) appear to reflect the stabilized eolian-dune and sandy-loess deposits, which formed during the Holocene directly on Pleistocene and Holocene soils (Brown and others, 1980). The carbonate mineral map is influenced by three different sources of calcium carbonate material: calichified soils, detrital calcite, and shell fragments (aragonite) (fig. 5). Shell fragments are most prevalent in the Holocene soils closest to the Rio Grande and the coastline. Caliche, the calcium- and magnesium-carbonate cemented soil layer that lies just beneath or at the soil surface, is indicated in the localized high concentrations of carbonates over the Goliad, Lissie, and Beaumont Formations. The soils with high potassium-feldspar concentrations appear to be coincident with channels of older fluvialdeltaic sediments of the Beaumont and Lissie Formations (fig. 6). Soils with high concentrations of plagioclase are located on the younger Beaumont Formation and Holocene sediments (fig. 7) where the plagioclase has not been removed by weathering. Muscovite appears to be more abundant in soils that were developed on the Lissie Formation and the younger Holocene sediments (fig. 8). The concentrations of kaolinite (fig. 9) and smectite (fig. 10) are very low. The occurrences of both clay minerals appear to be greatest in the younger Beaumont Formation and Holocene fluvial-deltaic sediments. These low values, in large part, underrepresent the total amount present and are a result of the limitations of the Rietveld software used to quantify the mineralogy. 


\section{Conclusions}

This report describes the geochemical and mineral composition of 210 soil samples collected in the lower Rio Grande valley of Texas. These data have been used to better define geologic units (Page and others, 2006; Folger and others, 2006) and identify geographic areas that may be prone to mosquito breading (Hubbard and others, 2006).

\section{Acknowledgments}

The authors would like to thank Nadine Piatak, Bill Cannon, and Elizabeth Koozman of the U.S. Geological Survey (USGS) for their thoughtful comments. This research was supported by the USGS Landscape Geochemistry Project and the Border Environmental Health Initiative.

\section{References Cited}

Brantley, S.L., Goldhaber, M.B., and Ragnarsdottir, K.V., 2007, Crossing disciplines and scales to understand the critical zone, in Brantley, S.L., White, T.S., and Ragnarsdottir, K.V., eds., The critical zone-Where rock meets life: Elements, v. 3, no. 5, p. 30-314.

Briggs, P.H., and Meier, A.L., 2002, The determination of forty-two elements in geological materials by inductively coupledmass spectrometry, in Taggart, J.E., ed., Analytical methods for chemical analysis of geologic and other materials, U.S. Geological Survey: U.S. Geological Survey Open-File Report 02-223-I, 14 p.

Brown, L.F., Jr., Brewton, J.L., Evans, T.J., McGowen, J.H., White, W.A., Groat, C.G., and Fisher, W.L., 1980, Environmental geologic atlas of the Texas coastal zone; Brownsville Harlingen area: Bureau of Economic Geology, The University of Texas at Austin, $140 \mathrm{p}$.

Brown, Z.A., O’Leary, R.M., Hageman, P.L., and Crock, J.G., 2002, Mercury in water, geologic, and plant materials by continuous flow-cold vapor-atomic absorption spectrometry, in Taggart, J.E., ed., Analytical methods for chemical analysis of geologic and other materials, U.S. Geological Survey: U.S. Geological Survey Open-File Report 02-223-M, 9 p.

Buckler, D., and Strom, E., 2004, Science data in support of environmental health studies in the U.S.-Mexico border region: U.S. Geological Survey Fact Sheet 2004-3013, 2 p.

Bureau of Economic Geology, 1976, Geologic atlas of Texas, McAllen-Brownsville sheet: Austin, Tex., Bureau of Economic Geology Geologic Atlas Series, scale 1:250,000.

Duval, J.S., 2005, Radon in soils of parts of Cameron, Hidalgo, and Willacy Counties, Texas: U.S. Geological Survey Open-File Report 2005-1423, accessed on May 31, 2011, at http://pubs.usgs.gov/of/2005/1423.

Folger, H.W., Hubbard, B.E., Duval, J., McCafferty, A., and Page, W.R., 2006, Synergistic use of airborne gamma-ray survey data and ASTER imagery for mapping cross-border radon potential in the lower Rio Grande valley, south Texas, USA and north Tamaulipas, Mexico [abs.]: Geological Society of America South-Central Section Annual Meeting, March 6-7, 2006, Abstracts with Programs, v. 38, no. 1, p. 7.

Galloway, W.E., Ganey-Curry, P.E., Li, X., and Buffler, R.T., 2000, Cenozoic depositional history of the Gulf of Mexico basin: AAPG Bulletin, v. 84, no. 11, p. 1743-1774.

Hageman, P.L., Brown, Z.A., and Welsch, E., 2002, Arsenic and selenium by flow injection or continuous flow-hydride generation-atomic absorption spectrophotometry, in Taggart, J.E., ed., Analytical methods for chemical analysis of geologic and other materials, U.S. Geological Survey: U.S. Geological Survey Open-File Report 02-223-L, 7 p.

Helsel, D.R., and Hirsch, R.M., 2002, Statistical methods in water resources: U.S. Geological Survey Techniques of WaterResources Investigations, book 4, chap. A3, 510 p. 
Hubbard, B.E., Folger, H.W., and Page, W.R., 2010, Remote sensing assessment of soil moisture, soil mineralogy and other environmental factors influencing mosquito-borne infection risks in the Lower Rio Grande Valley, U.S.-Mexico Border [abs.]: American Geophysical Union, Fall Meeting, San Francisco, Calif., abstract no. H14C-06.

Hubbard, B.E., Folger, H.W., Parcher, J.W., and Page, W.R., 2006, Multi-temporal remote sensing assessment of soil moisture and vector-borne disease potential in the Pleistocene Beaumont and Lower Rio Grande Delta, Southern Texas and Northern Tamaulipas, U.S.-Mexico Border Region [abs.]: Geological Society of America South-Central Section Annual Meeting, March 6-7, 2006, Abstracts with Programs, v. 38, no. 1, p. 7.

Jacobs, J.L., 1981, Soil survey of Hidalgo County, Texas: Washington, D.C., United States Department of Agriculture, Soil Conservation Service, $171 \mathrm{p}$.

Mangum, A.W., and Lee, O., Jr., 1907, Soil survey of the Brownsville area, Texas: Natural Resources Conservation Service web page, accessed November 15, 2013, at http://soils.usda.gov/survey/online_surveys/texas/brownsvilleTX1907/brownsvilleTX1907.pdf..

Menne, M.J., Durre, I., Korzeniewski, B., McNeal, S., Thomas, K., Yin, X., Anthony, S., Ray, R., Vose, R.S., Gleason, B.E., and Houston, T.G., 2012, Global Historical Climatology Network-Daily (GHCN-Daily), v. 3.22: National Oceanic and Atmospheric Administration National Climatic Data Center web page, accessed October 8, 2014, at http://www.nws.noaa.gov/ climate/.

Merrill, M.D., Folger, H.W., Hubbard, B.E., and Page, W.R., 2006, Soil geochemistry and geology in the lower Rio Grande valley, Texas [abs.]: Geological Society of America Abstracts with Programs, v. 38, no. 7, p. 136.

National Oceanic and Atmospheric Administration, 2014, Climate service: National Oceanic and Atmospheric Administration web page, accessed October 8, 2014, at http://www.ncdc.noaa.gov/.

Page, W.R., Hubbard, B.E., Duval, J.S., Folger, H.W., McCafferty, A.E., Parcher, J.W., and Wilson, Z.D., 2006, Template for compiling binational geologic map datasets in the U.S.-Mexico border region; an example from southern Texas and northern Mexico, U.S.-Mexico border environmental health initiative [abs.]: Geological Society of America South-Central Section Annual Meeting, March 6-7, 2006, Abstracts with Programs, v. 38, no. 1, p. 7.

Page, W.R., Van Sistine, D.P., and Turner, K.J., 2005, Preliminary geologic map of southernmost Texas, United States, and parts of Tamaulipas and Nuevo Leon, Mexico-Environmental Health Investigations in the United States-Mexico border region: U.S. Geological Survey Open-File Report 2005-1409, accessed December 2011 at http://pubs.usgs.gov/of/2005/1409.

Papoulias, D., Parcher, J., Stefanov, J., and Page, R., 2006, Interdisciplinary science in support of environmental health along the United States-Mexico Border: U.S. Geological Survey Fact Sheet 2006-3054, 2 p.

Parcher, J.W., 2008, U.S.-Mexico border geographic information system: U.S. Geological Survey Fact Sheet 2008-3069, 4 p.

Smith, D.B., Woodruff, L.G., O’Leary, R.M., Cannon, W.F., Garrett, R.G., Kilburn, J.E., and Goldhaber, M.B., 2009, Pilot studies for the North American Soil Geochemical Landscapes Project—Site selection, sampling protocols, analytical methods, and quality control protocols: Applied Geochemistry, v. 24, no. 8, p. 1357-1368.

Taggart, J.E., Jr., and Siems, D.F., 2002, Major element analysis by wavelength dispersive x-ray fluorescence spectrometry, in Taggart, J.E., ed., Analytical methods for chemical analysis of geologic and other materials, U.S. Geological Survey: U.S. Geological Survey Open-File Report 02-223-T, 9 p.

Texas Department of State Health Services, 2012, Texas population, 2012: Texas Department of State Health Services web page, accessed November 4, 2013, at http://www.dshs.texas.gov/chs/popdat/st2012.shtm.

Thompson, C.M., Sanders, R.R., and Williams, D., 1972, Soil survey of Starr County, Texas: Washington, D.C., U.S. Department of Agriculture, Soil Conservation Service, 87 p.

Turner, A.J., 1982, Soil survey of Willacy County, Texas: Washington, D.C., U.S. Department of Agriculture, Soil Conservation Service, $137 \mathrm{p}$.

U.S. Census Bureau, 2000, Table DP-1. Profile of general demographic characteristics-2000 and 2010: American FactFinder web page, accessed November 4, 2013, at https://factfinder.census.gov/faces/nav/jsf/pages/index.xhtml. 
U.S. Geological Survey, 2011, ICP major element analysis using a lithium metaborate fusion, in Analytical contract laboratory method summaries: U.S. Geological Survey web page, accessed December 20, 2011, at http://minerals.cr.usgs.gov/projects/ analytical_chem/references.html.

Williams, D., Thompson, C.M., and Jacobs, J.L., 1977, Soil survey of Cameron County, Texas: Washington, D.C., U.S. Department of Agriculture, Soil Conservation Service, $92 \mathrm{p}$. 
Figure 17

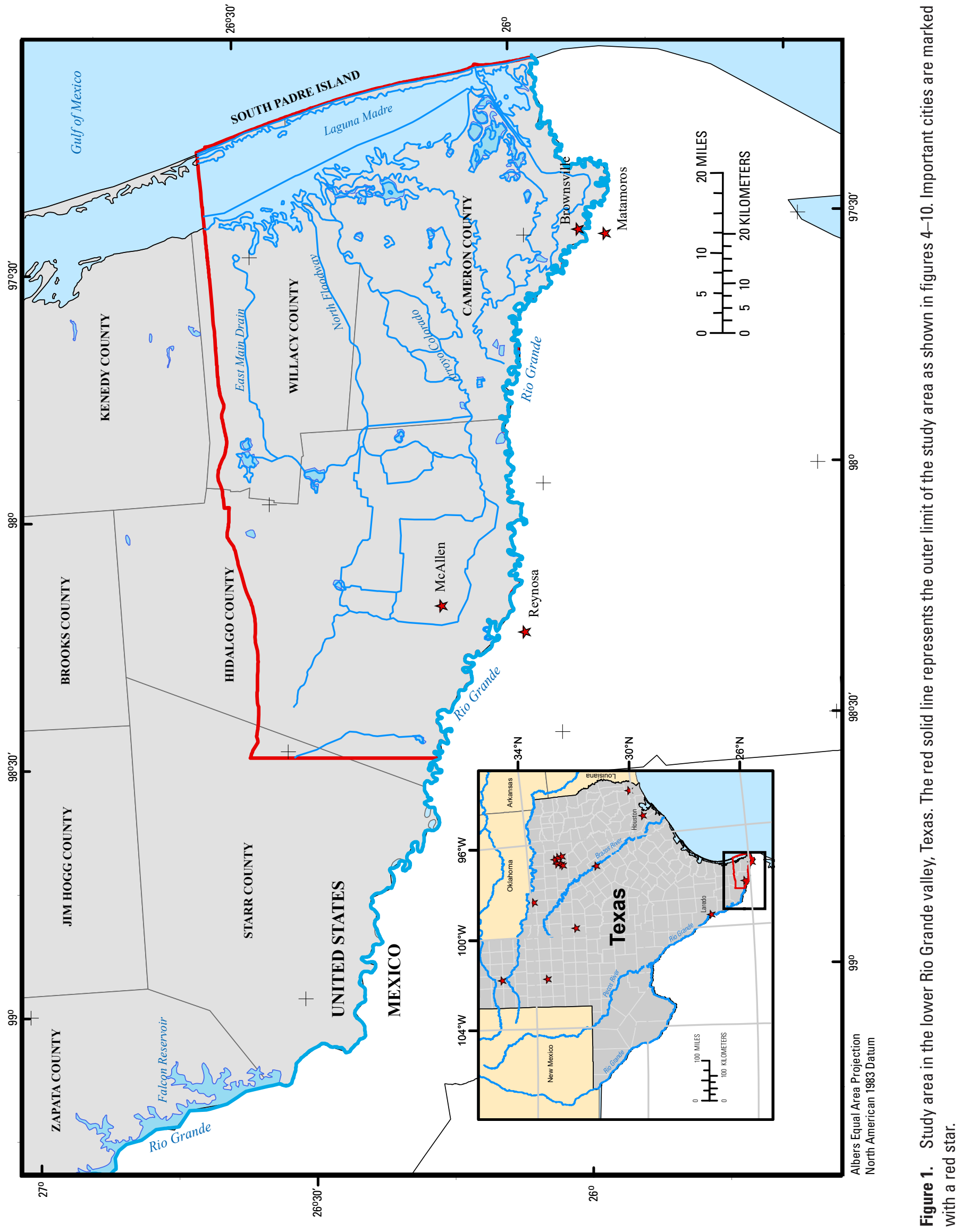




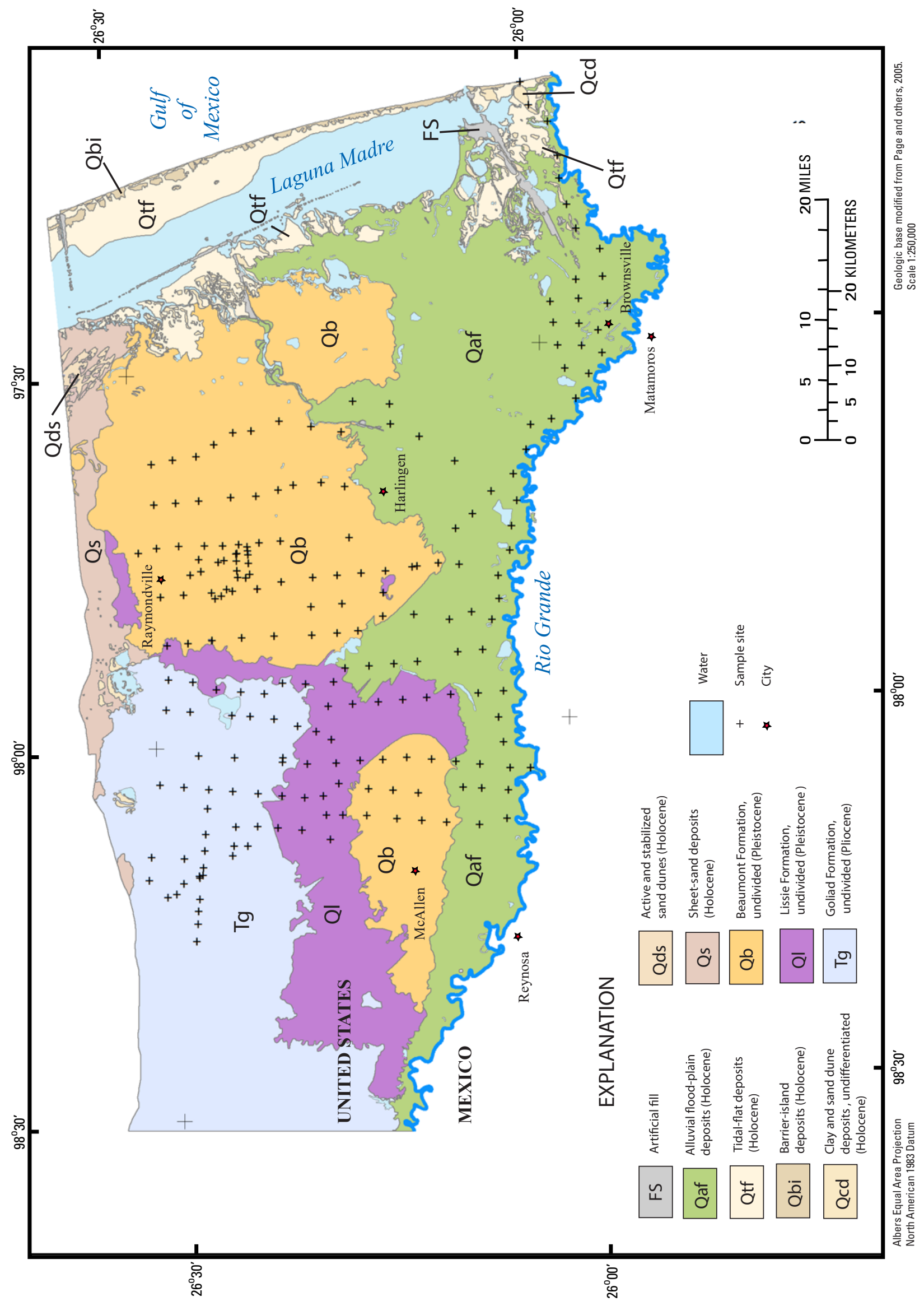

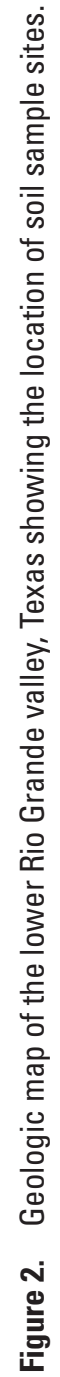



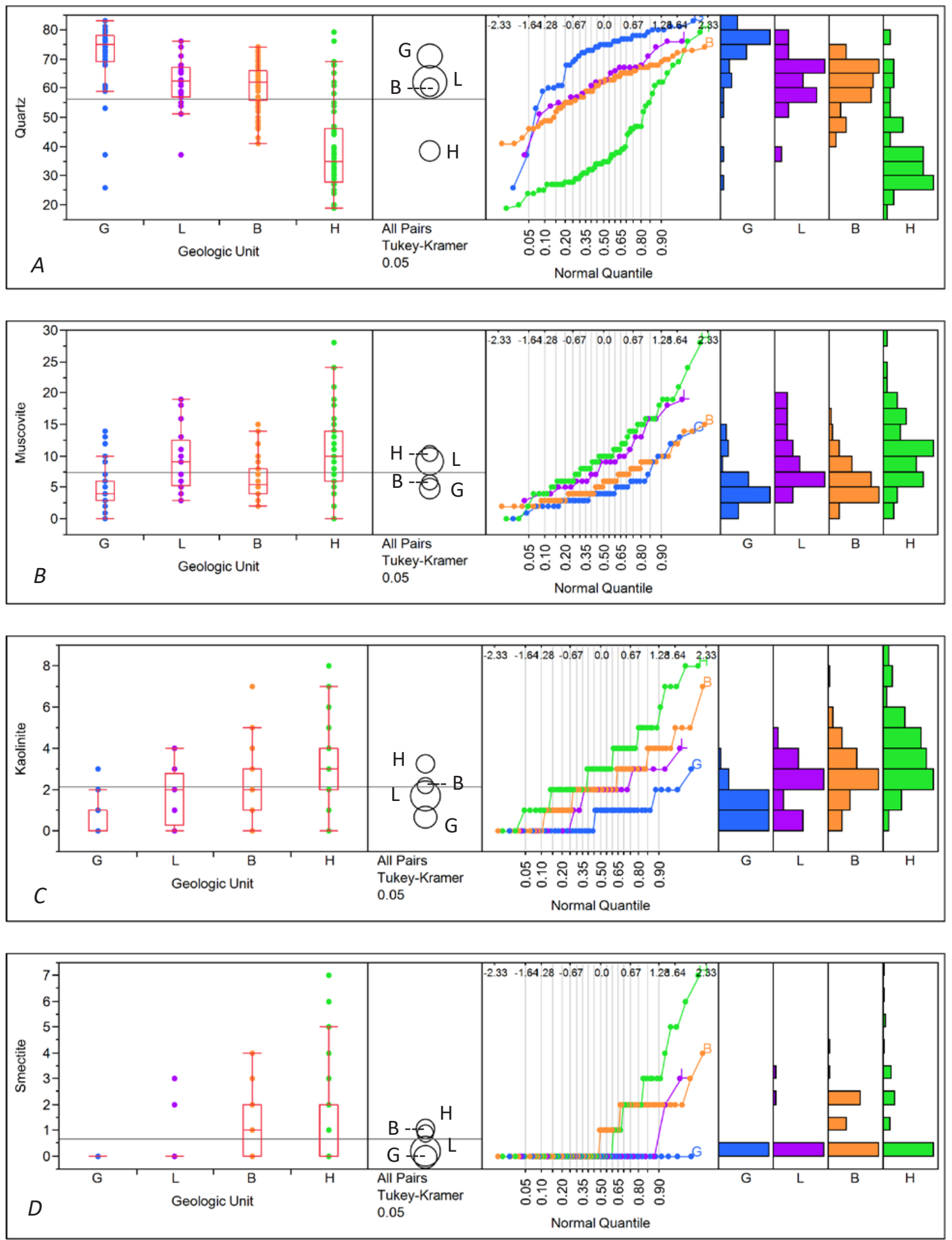

Figure 3. Univariate statistics for each of the seven major mineral groups $(A-G)$ identified in the soils from the lower Rio Grande valley. Each figure has four statistical diagrams that show the distribution patterns of each mineral group by geologic units. These diagrams are (from left to right): box plots showing interquartile range, comparison circles from the Tukey-Kramer comparison of means test, a normal quantile plot showing the actual data on a log-transformed scale, and histograms showing the distribution of the sampled soil population. The geologic units have been abbreviated in these figures. The units are $\mathrm{G}$ for Goliad Formation, $\mathrm{L}$ for Lissie Formation, B for Beaumont Formation, and $\mathrm{H}$ for Holocene alluvium. They are listed from oldest to youngest. Statistical methods are described in Helsel and Hirsch (2002). 

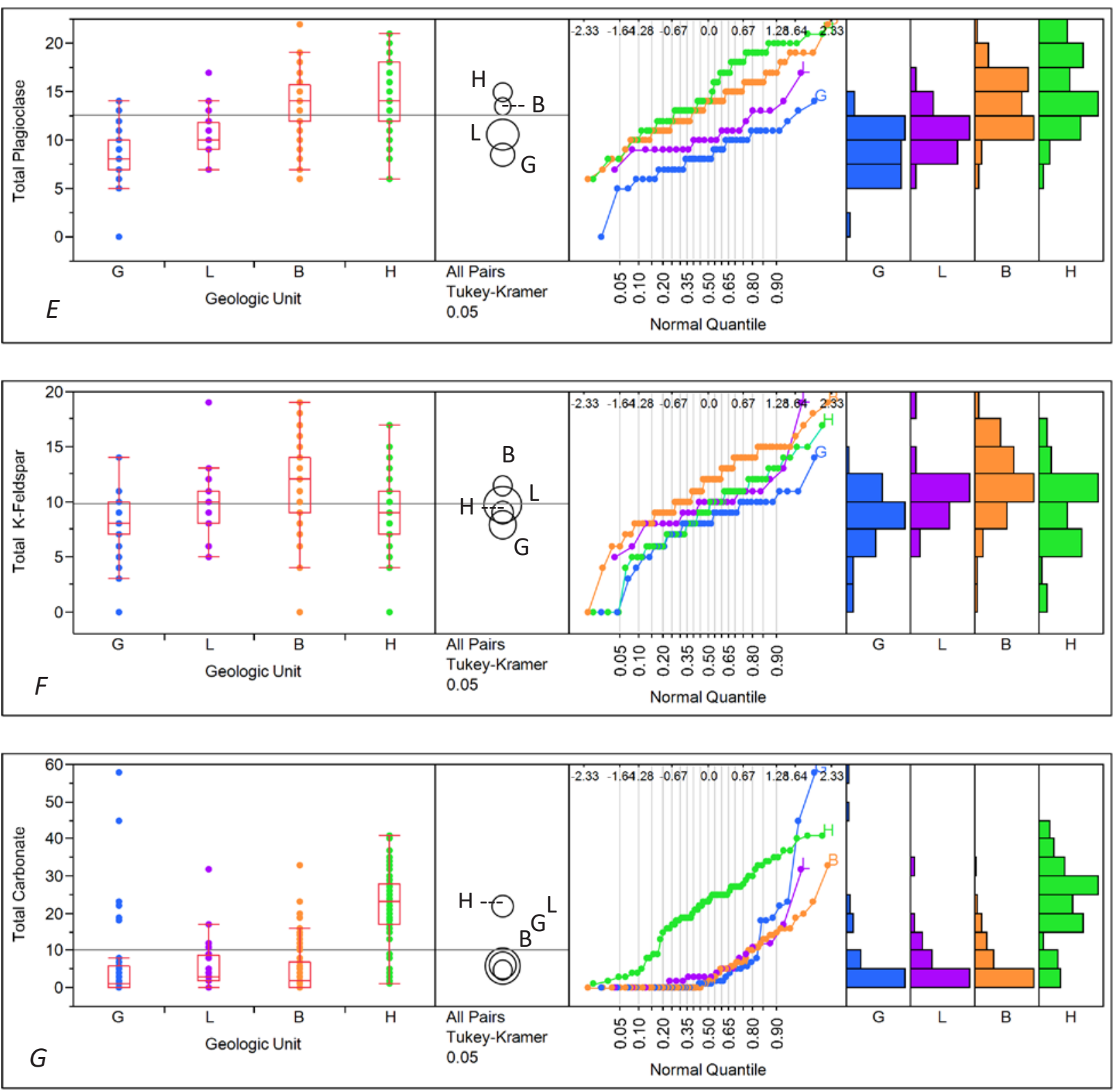

Figure 3. Univariate statistics for each of the seven major mineral groups $(A-G)$ identified in the soils from the lower Rio Grande valley. Each figure has four statistical diagrams that show the distribution patterns of each mineral group by geologic units. These diagrams are (from left to right): box plots showing interquartile range, comparison circles from the Tukey-Kramer comparison of means test, a normal quantile plot showing the actual data on a log-transformed scale, and histograms showing the distribution of the sampled soil population. The geologic units have been abbreviated in these figures. The units are $\mathrm{G}$ for Goliad Formation, L for Lissie Formation, B for Beaumont Formation, and $\mathrm{H}$ for Holocene alluvium. They are listed from oldest to youngest. Statistical methods are described in Helsel and Hirsch (2002).-Continued 


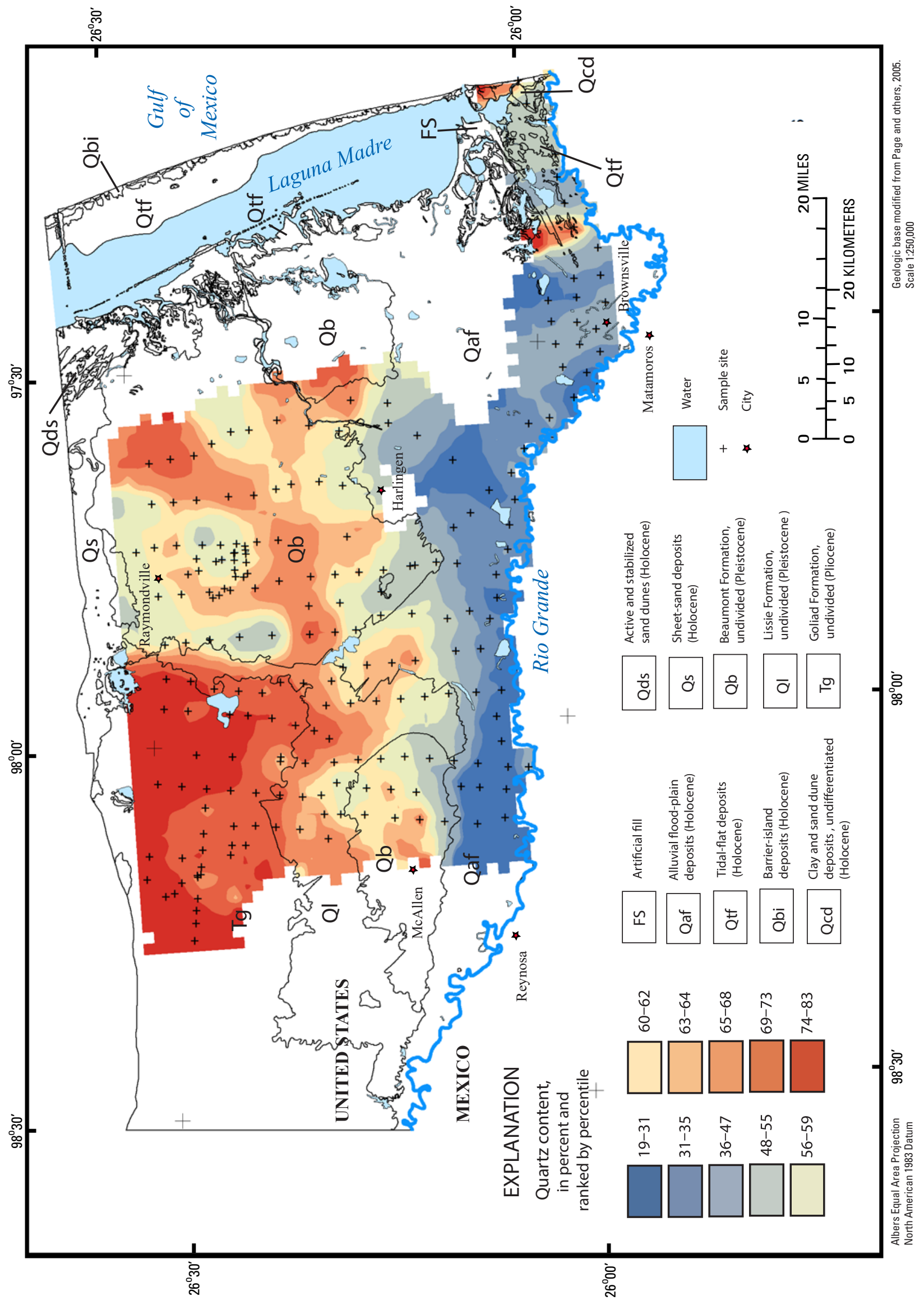

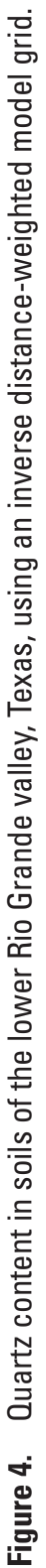




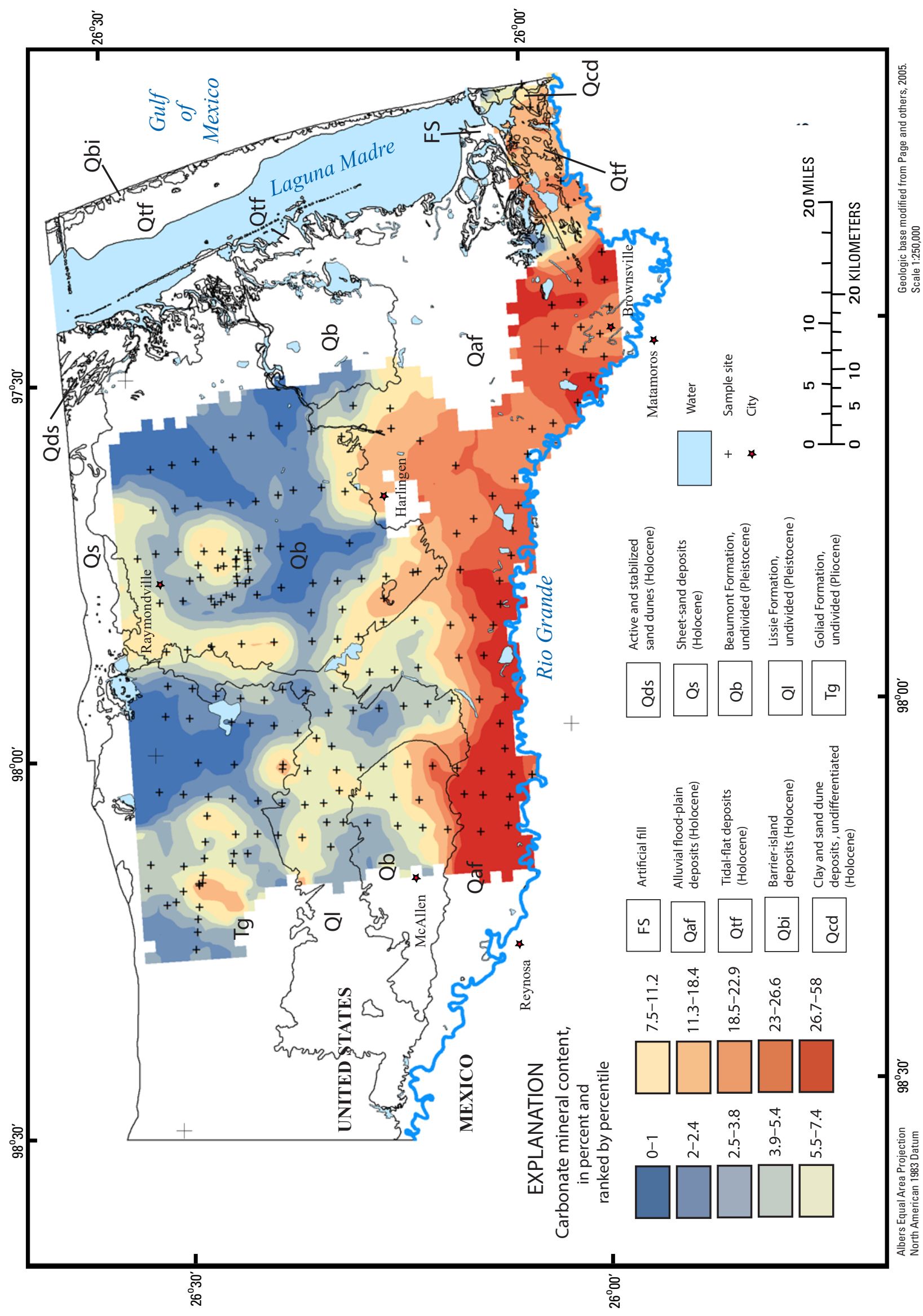

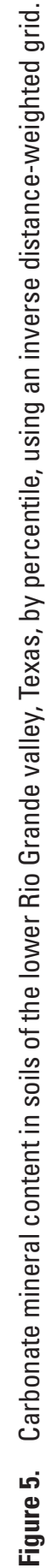




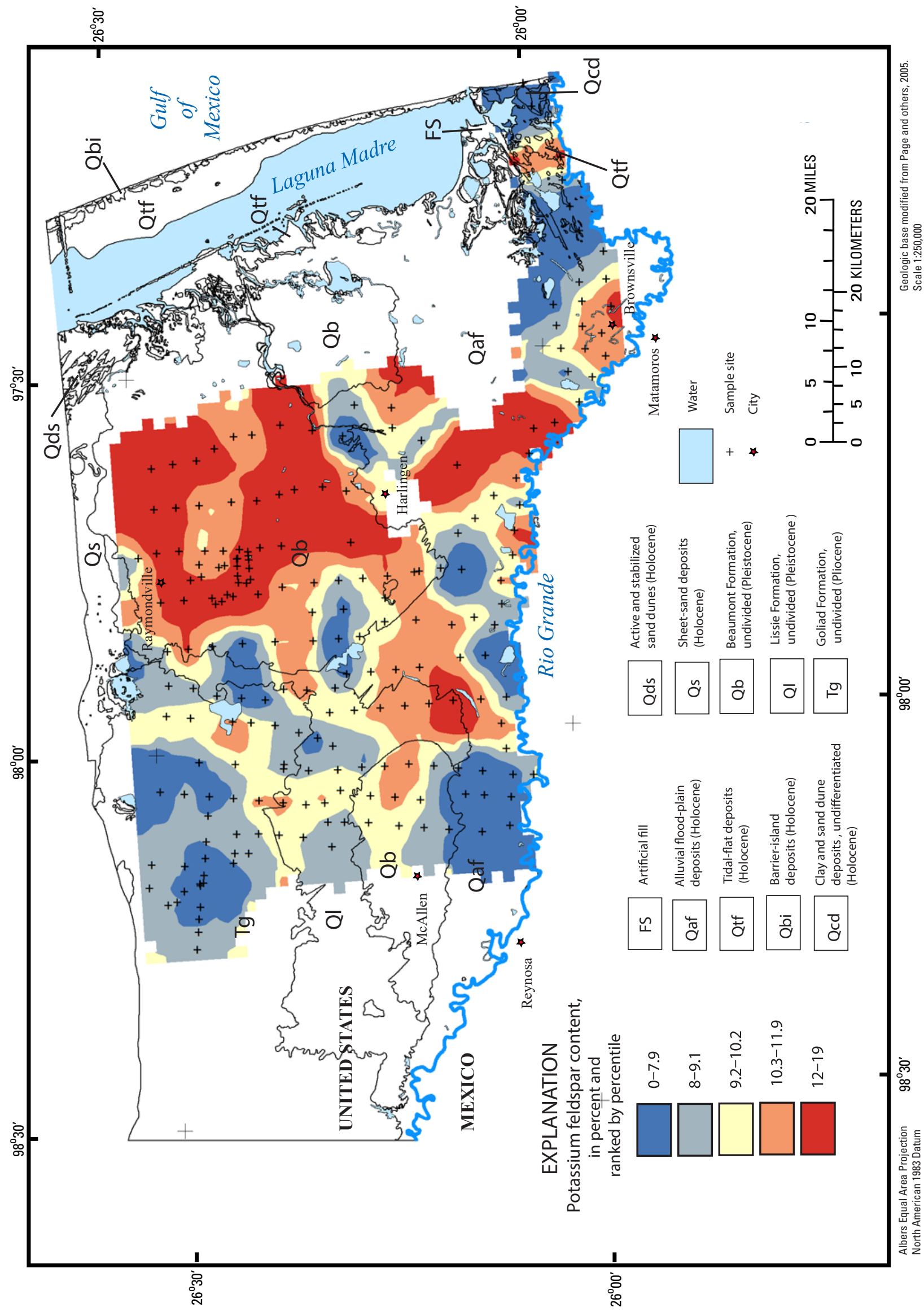

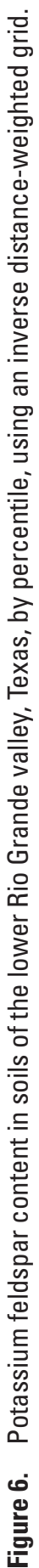




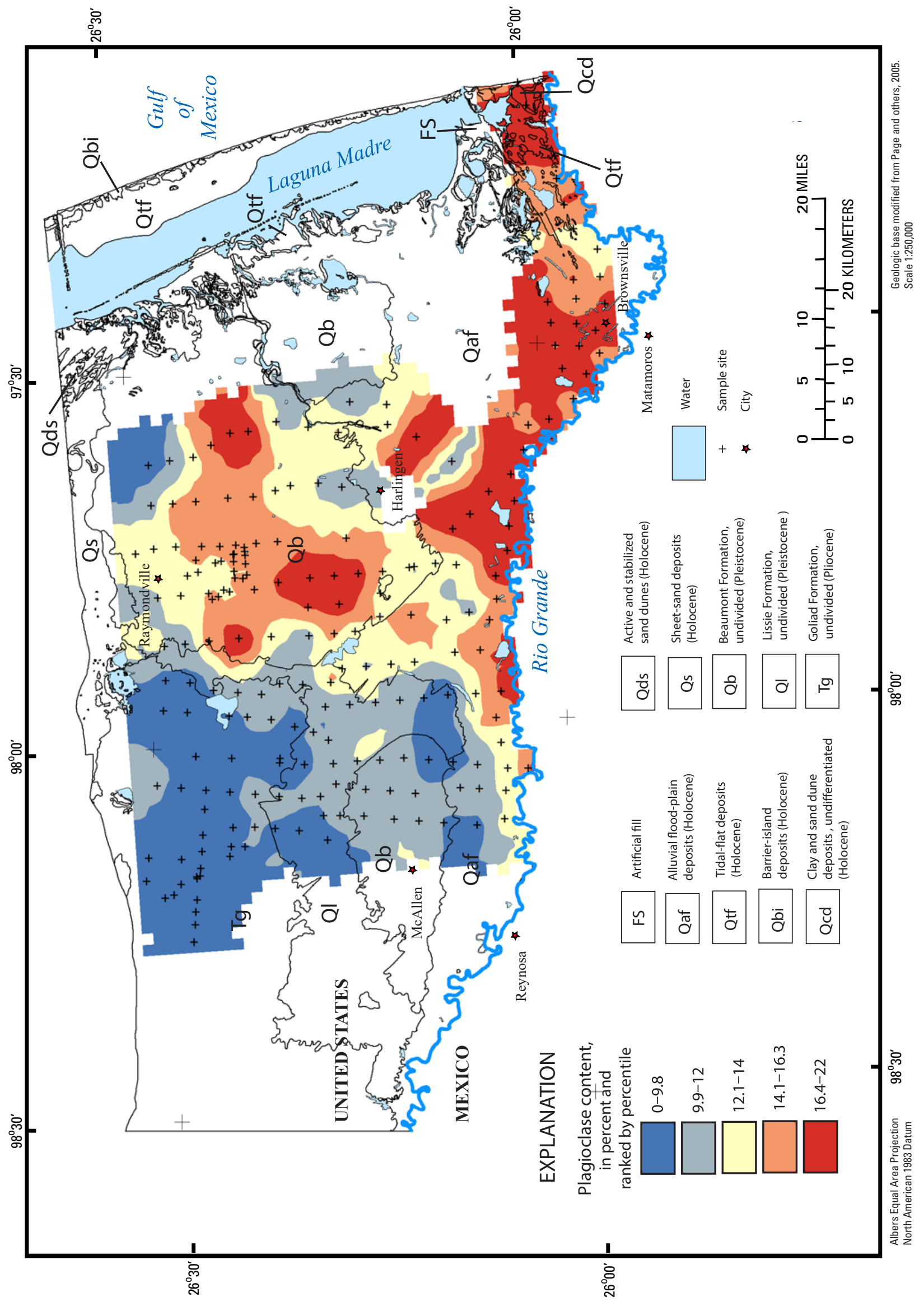

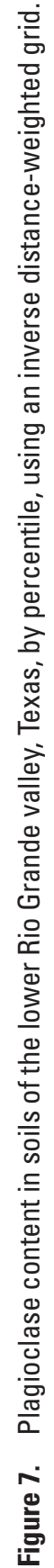




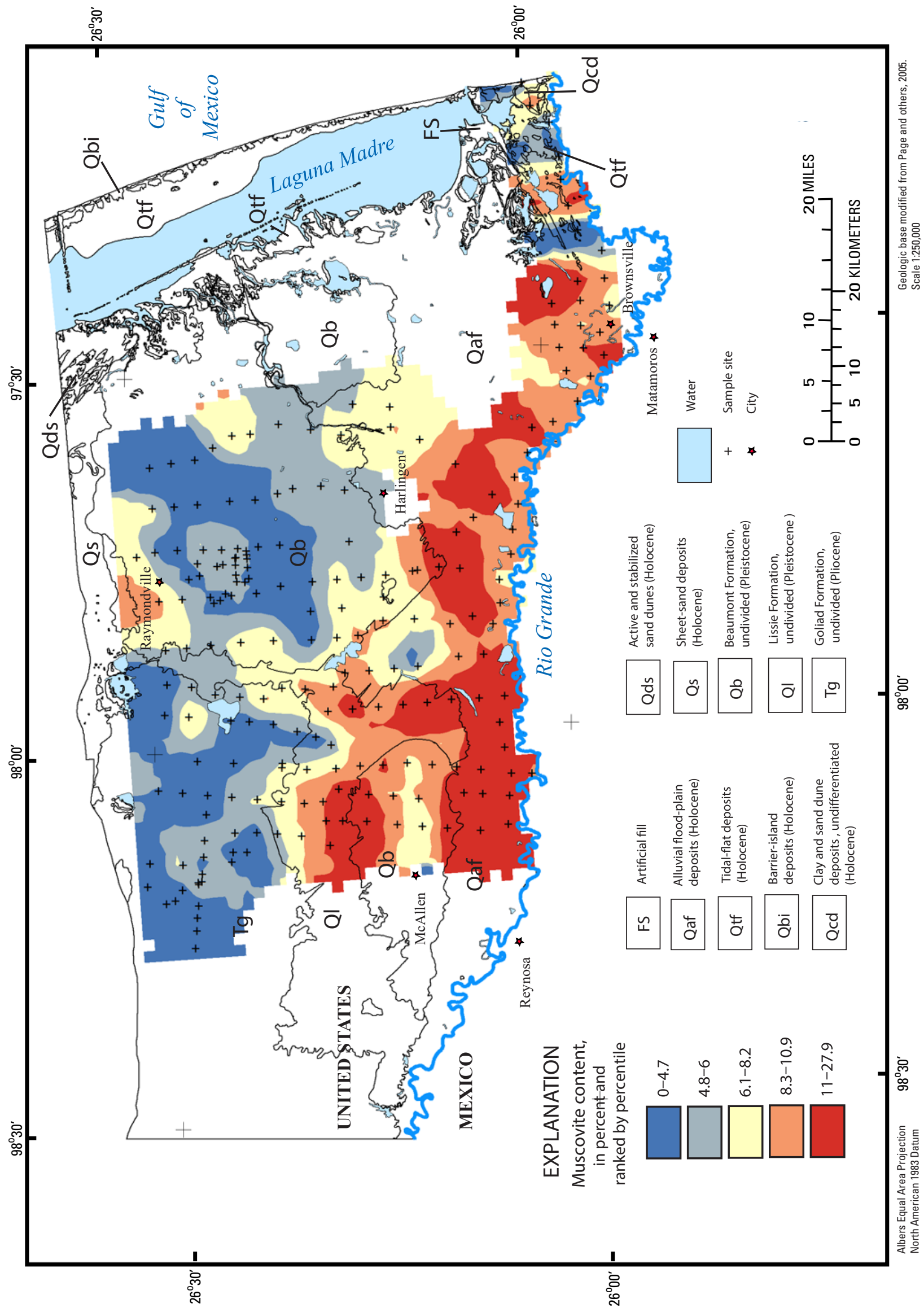

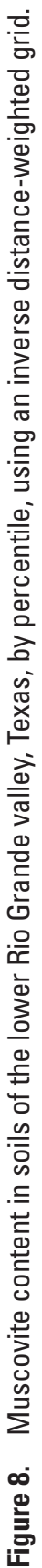




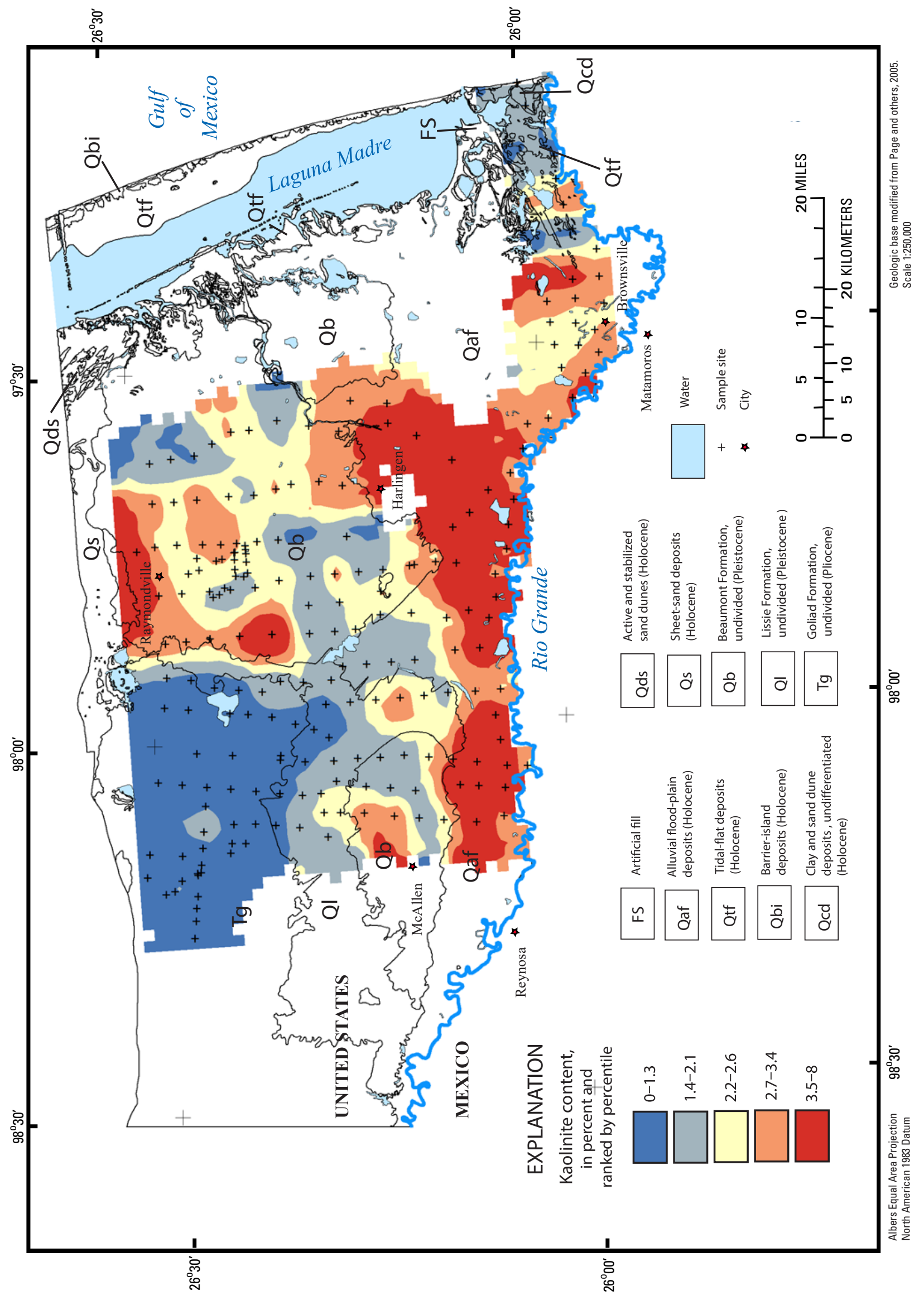

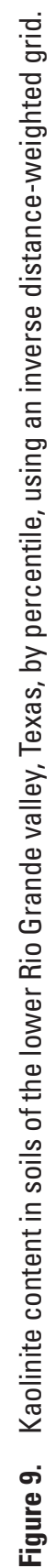




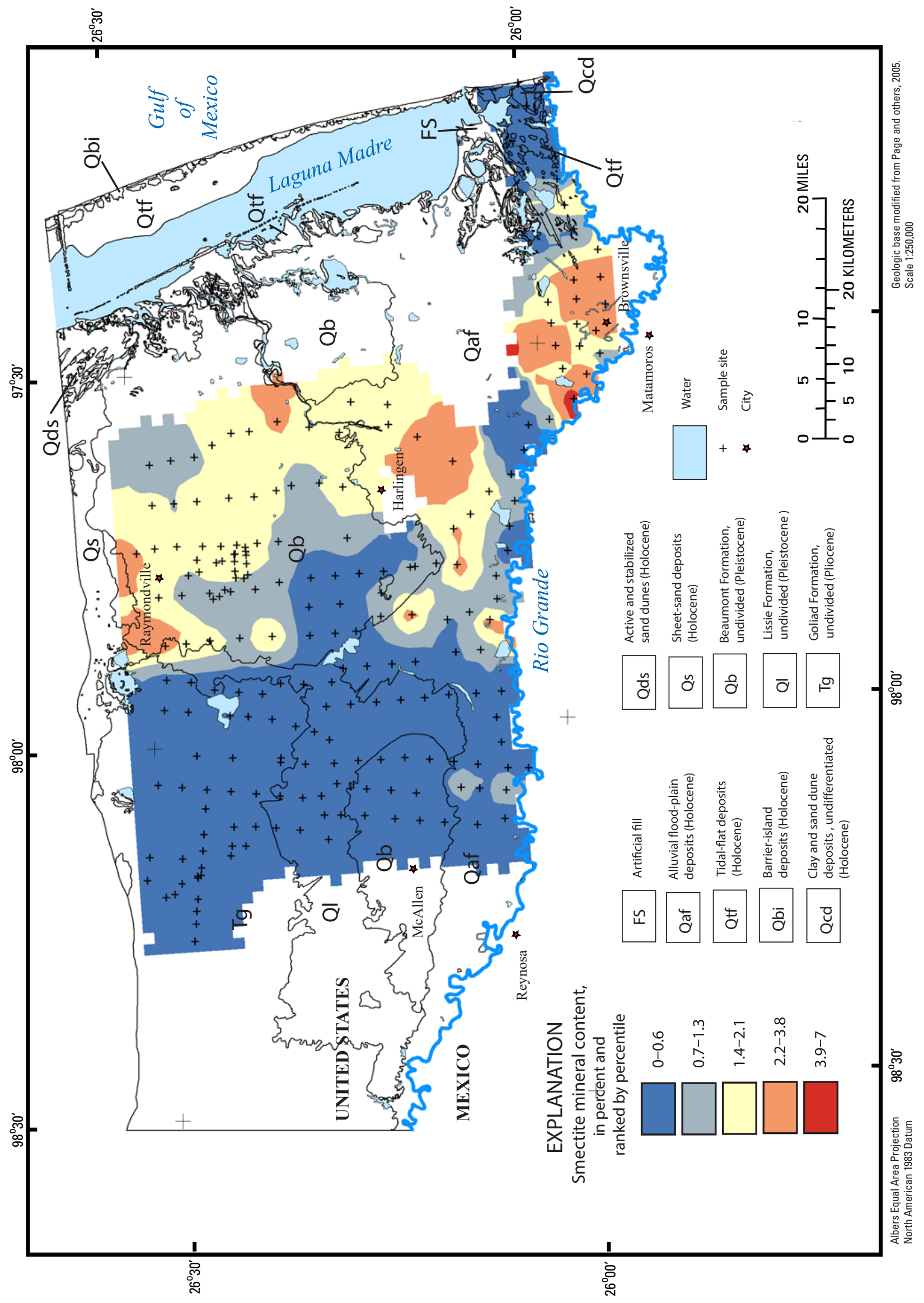

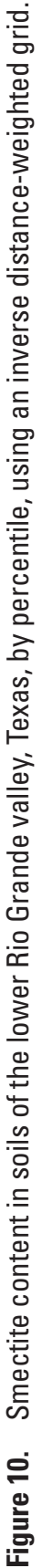




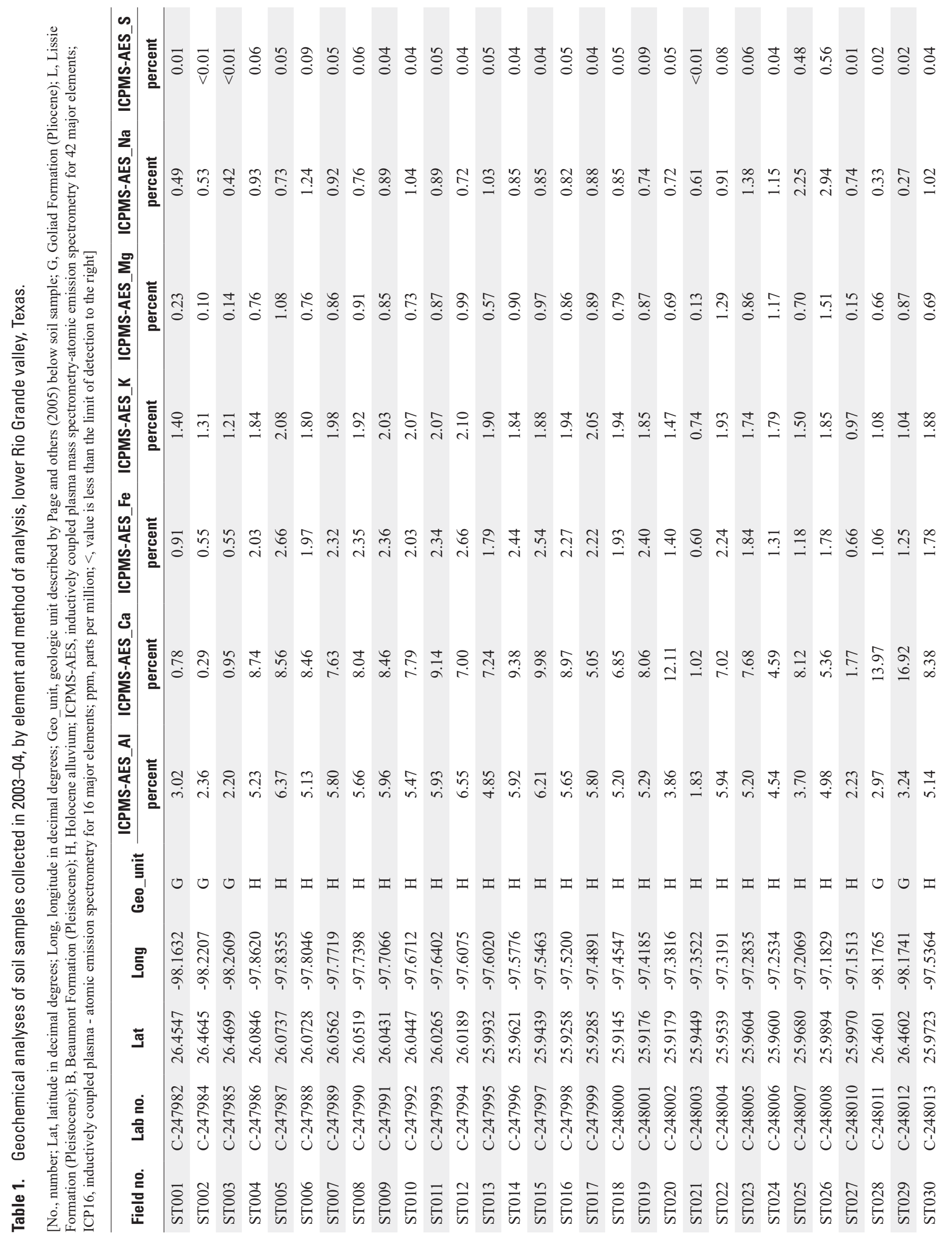




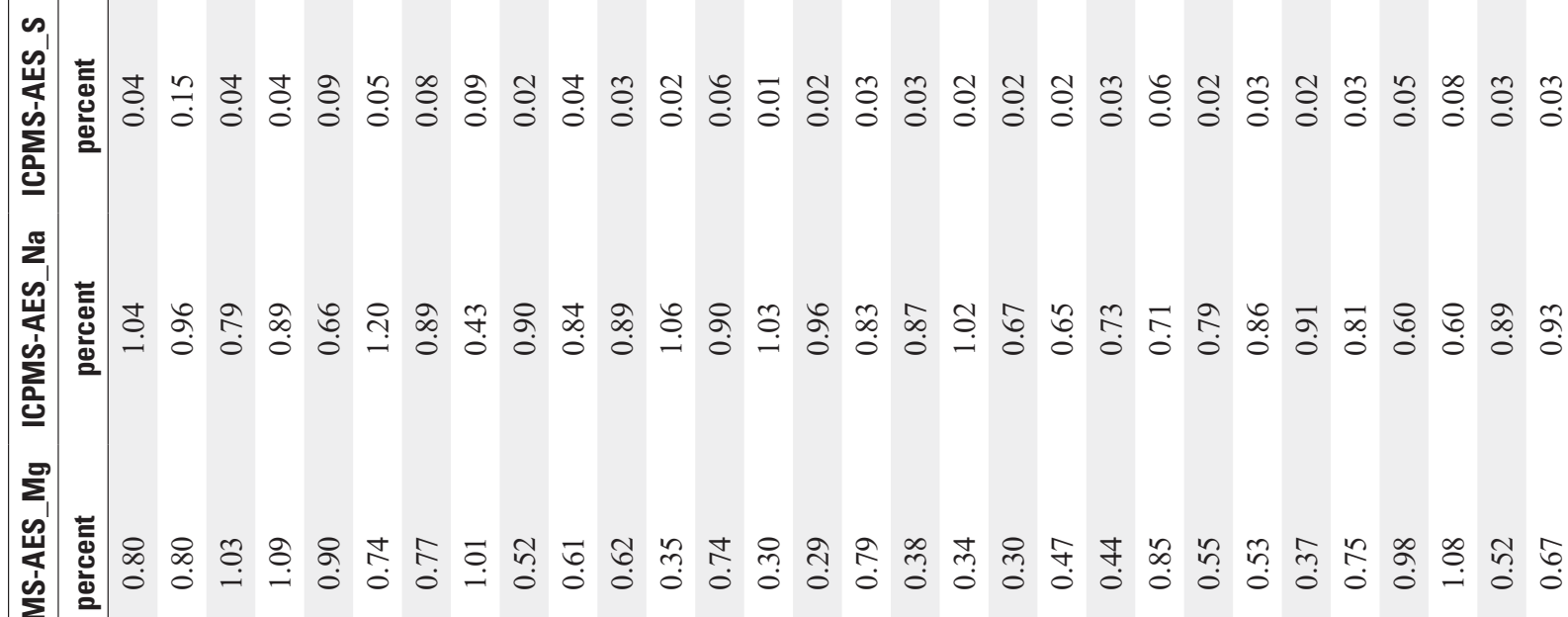

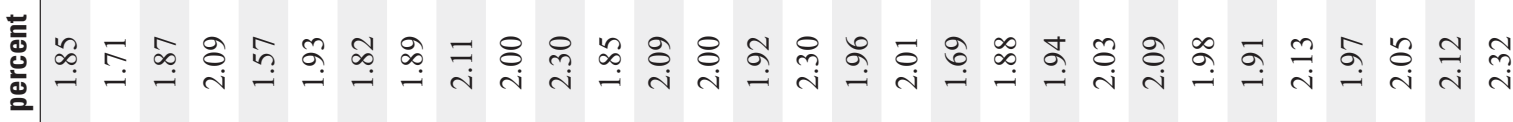

సิ ప

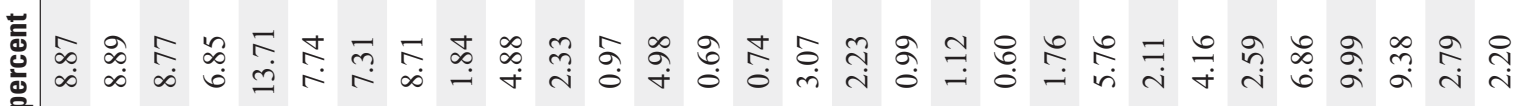

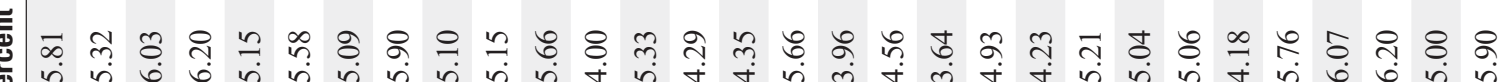

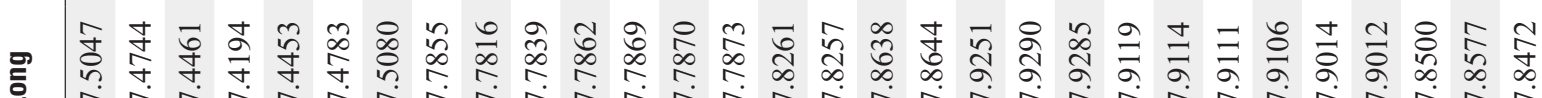




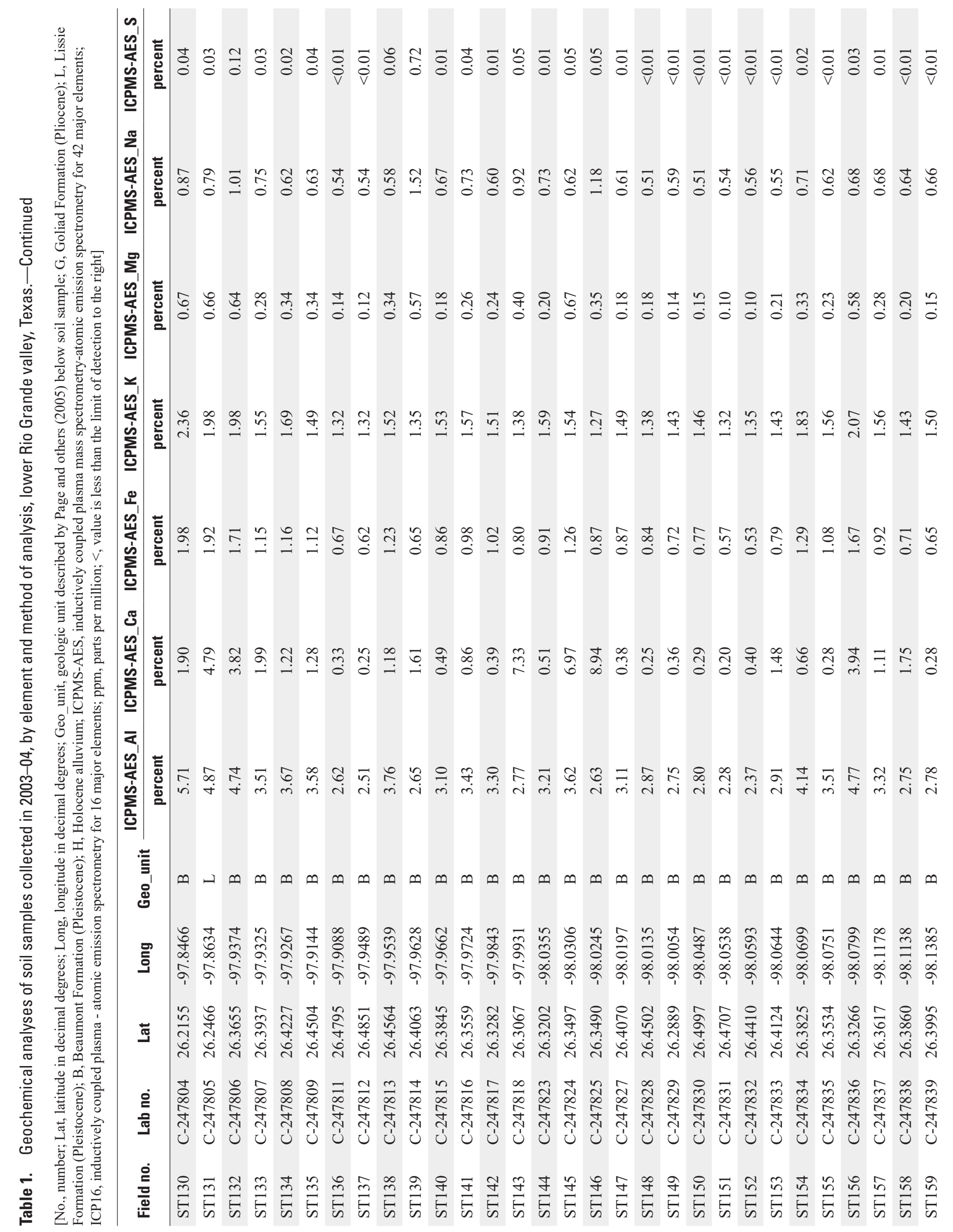




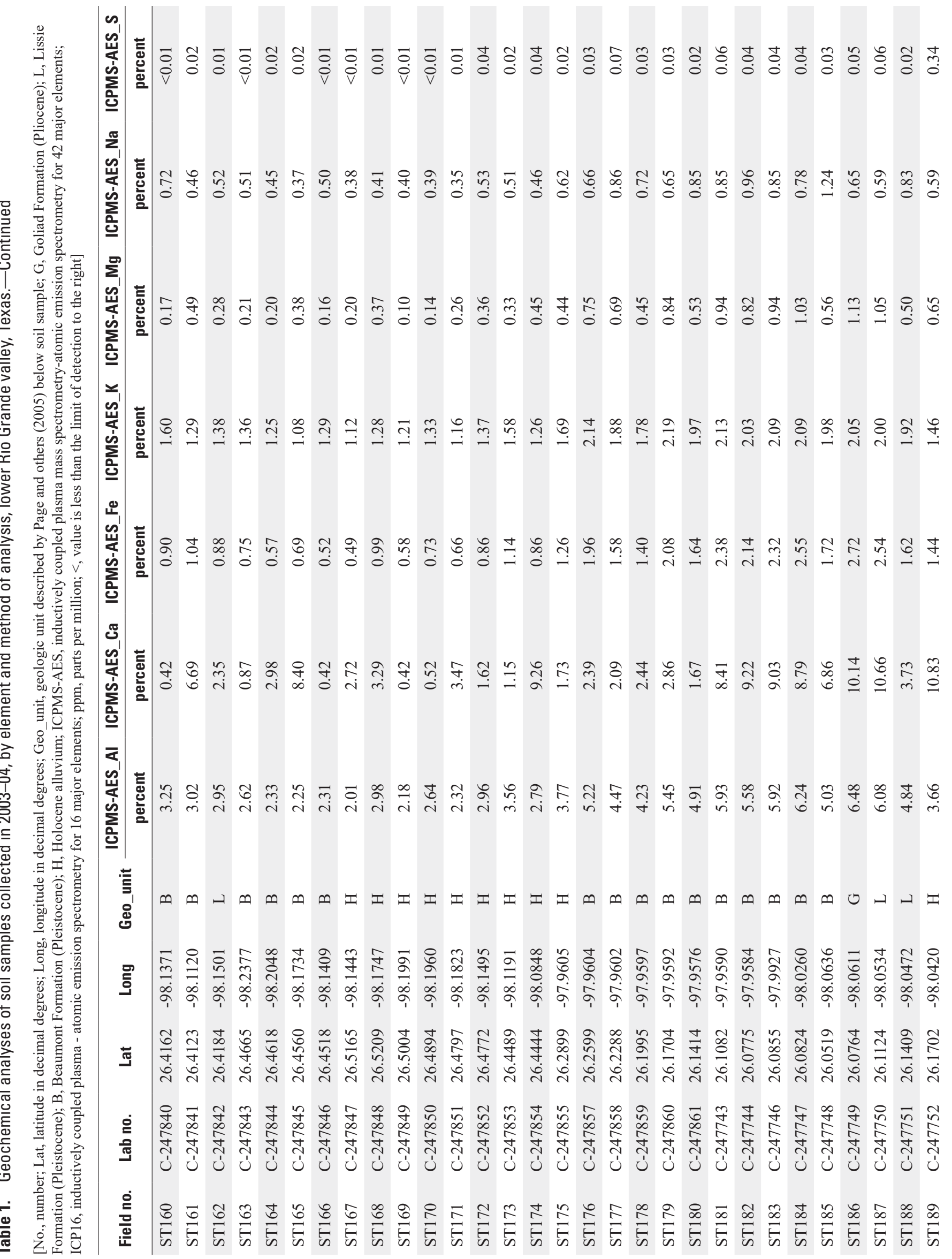




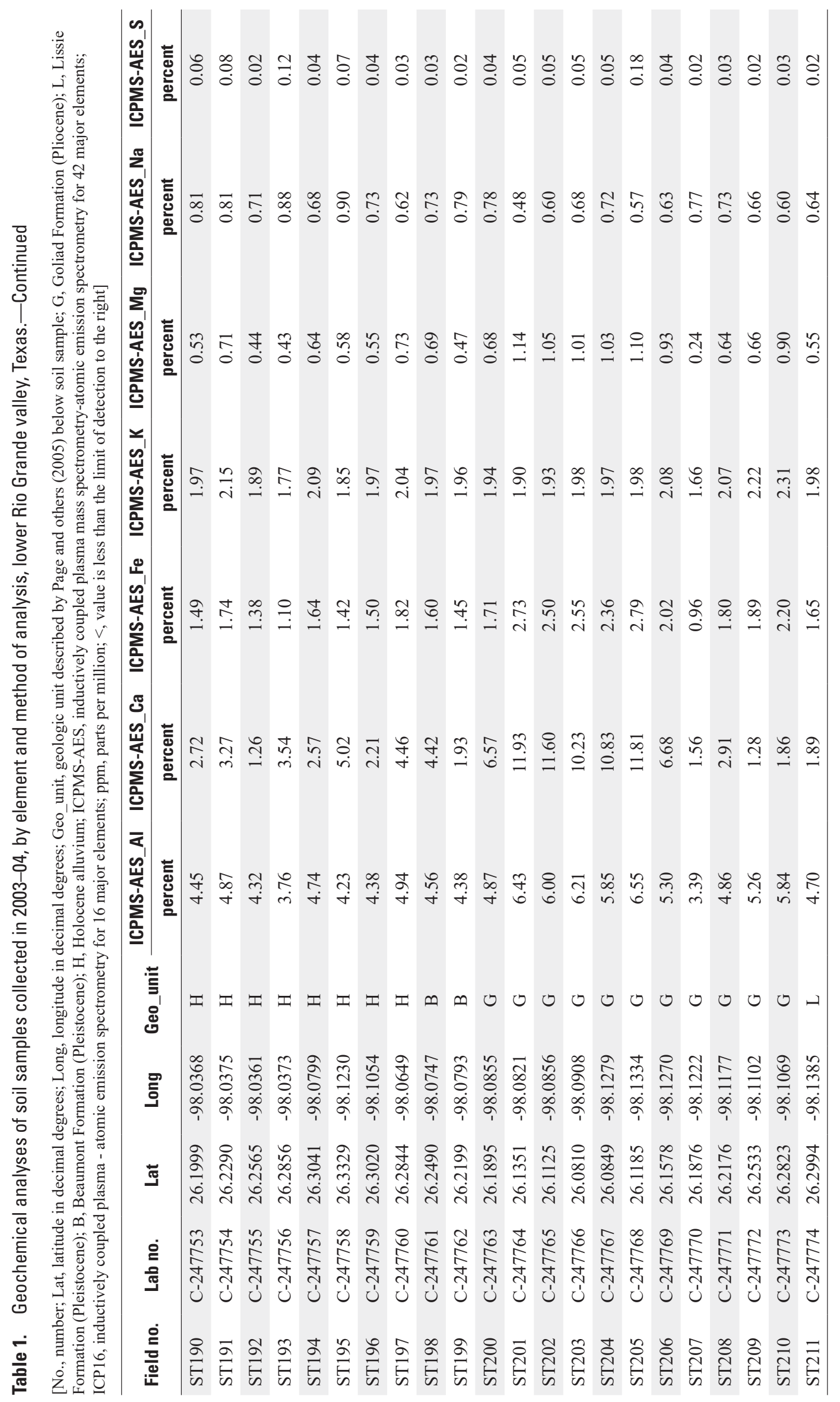




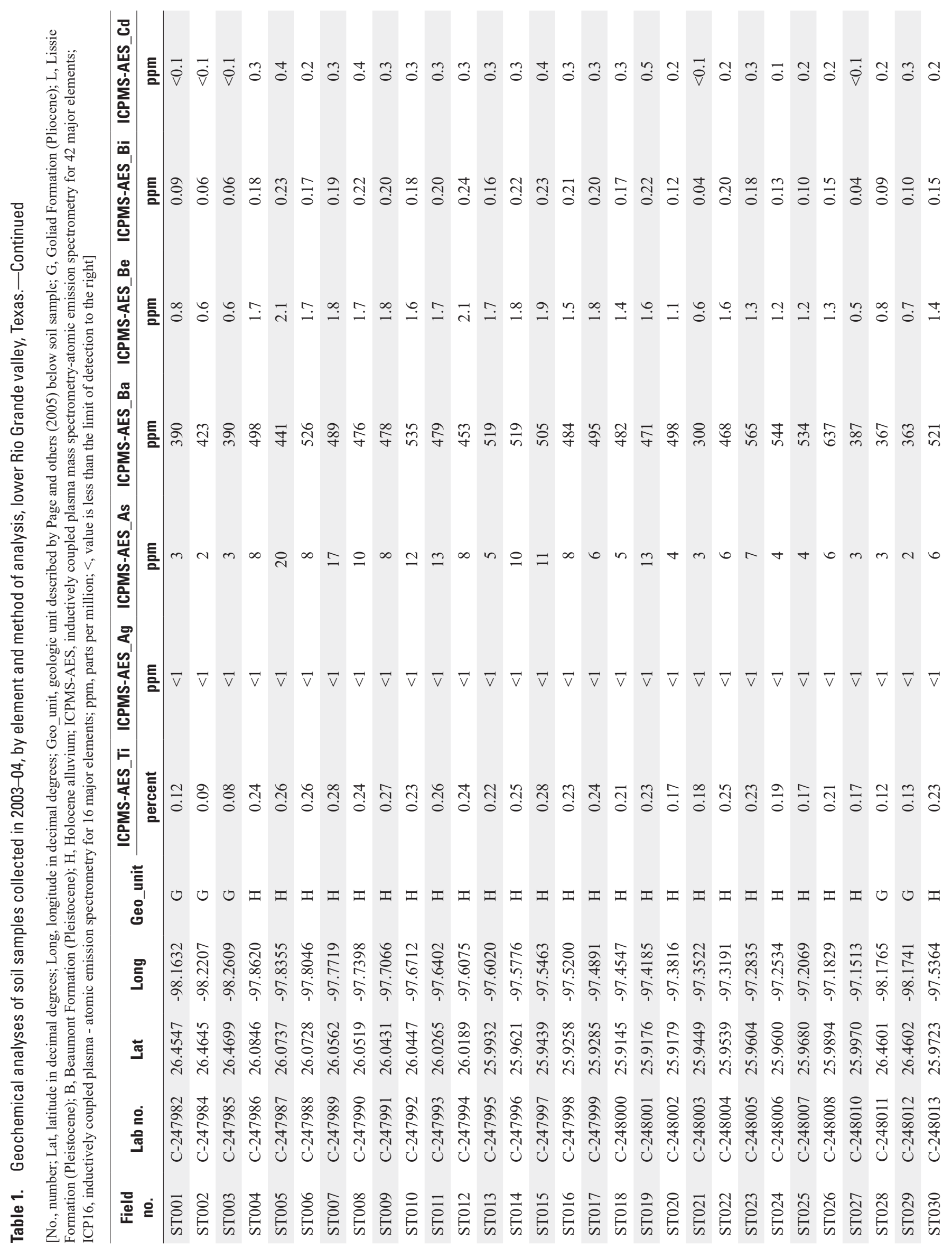




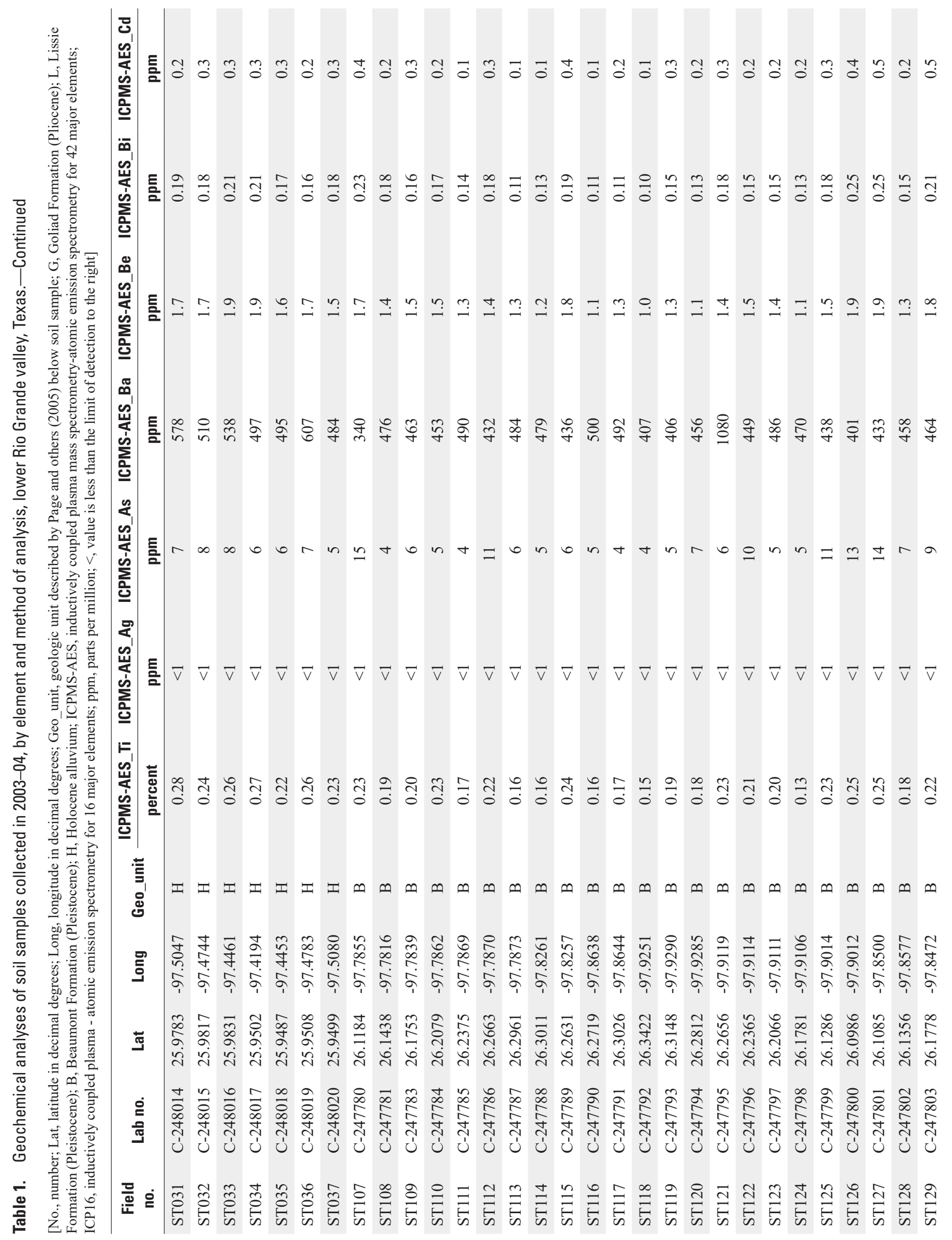




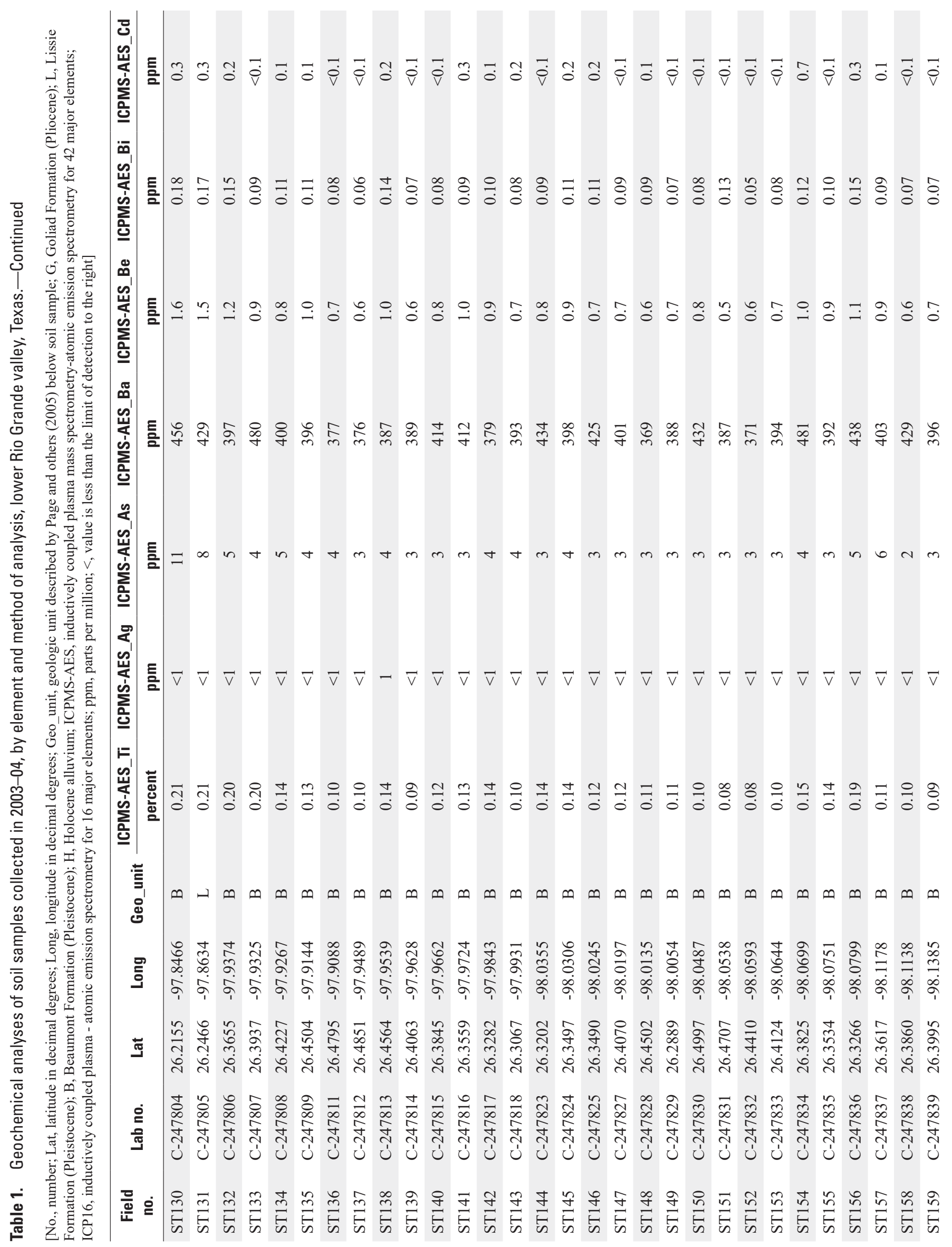




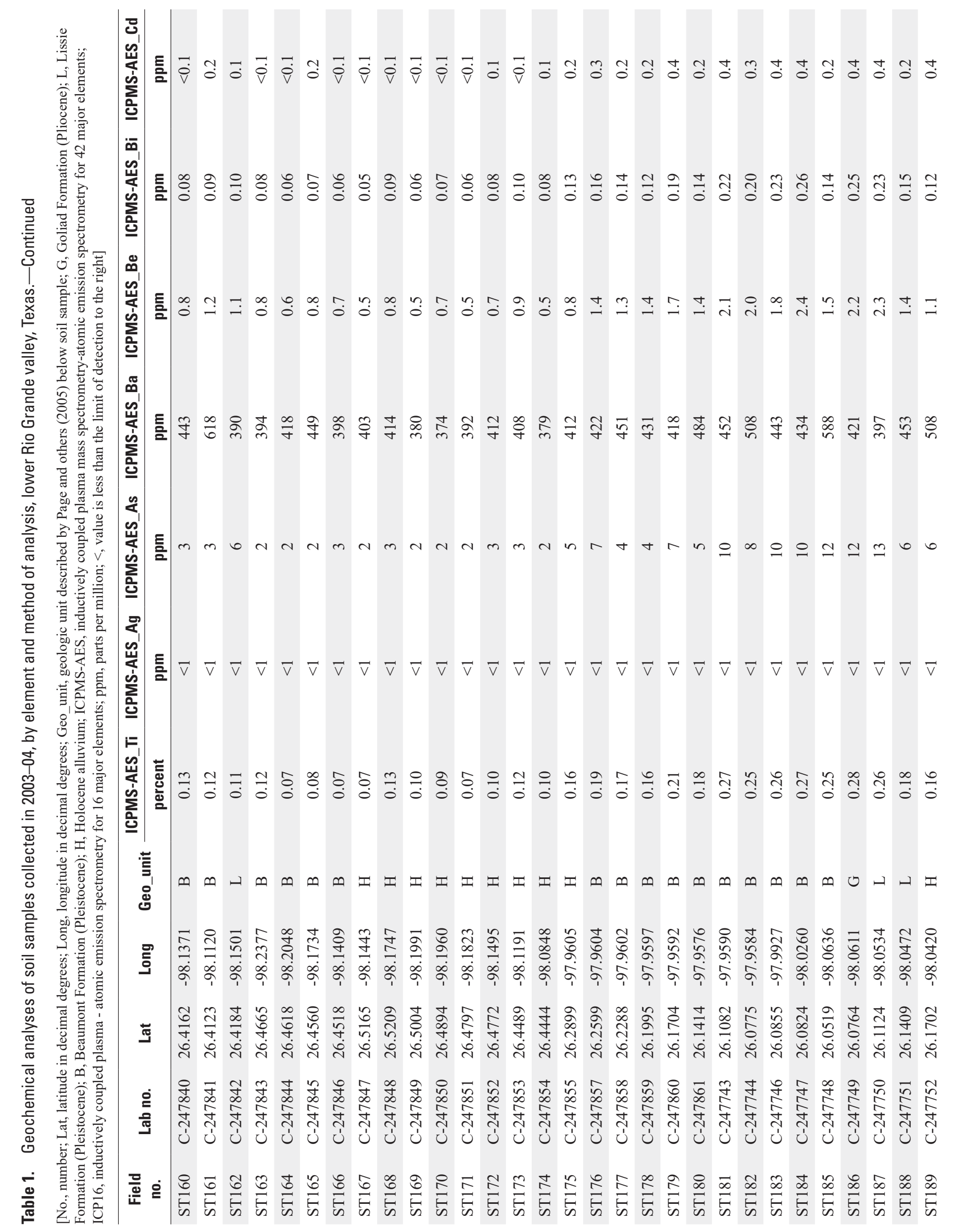




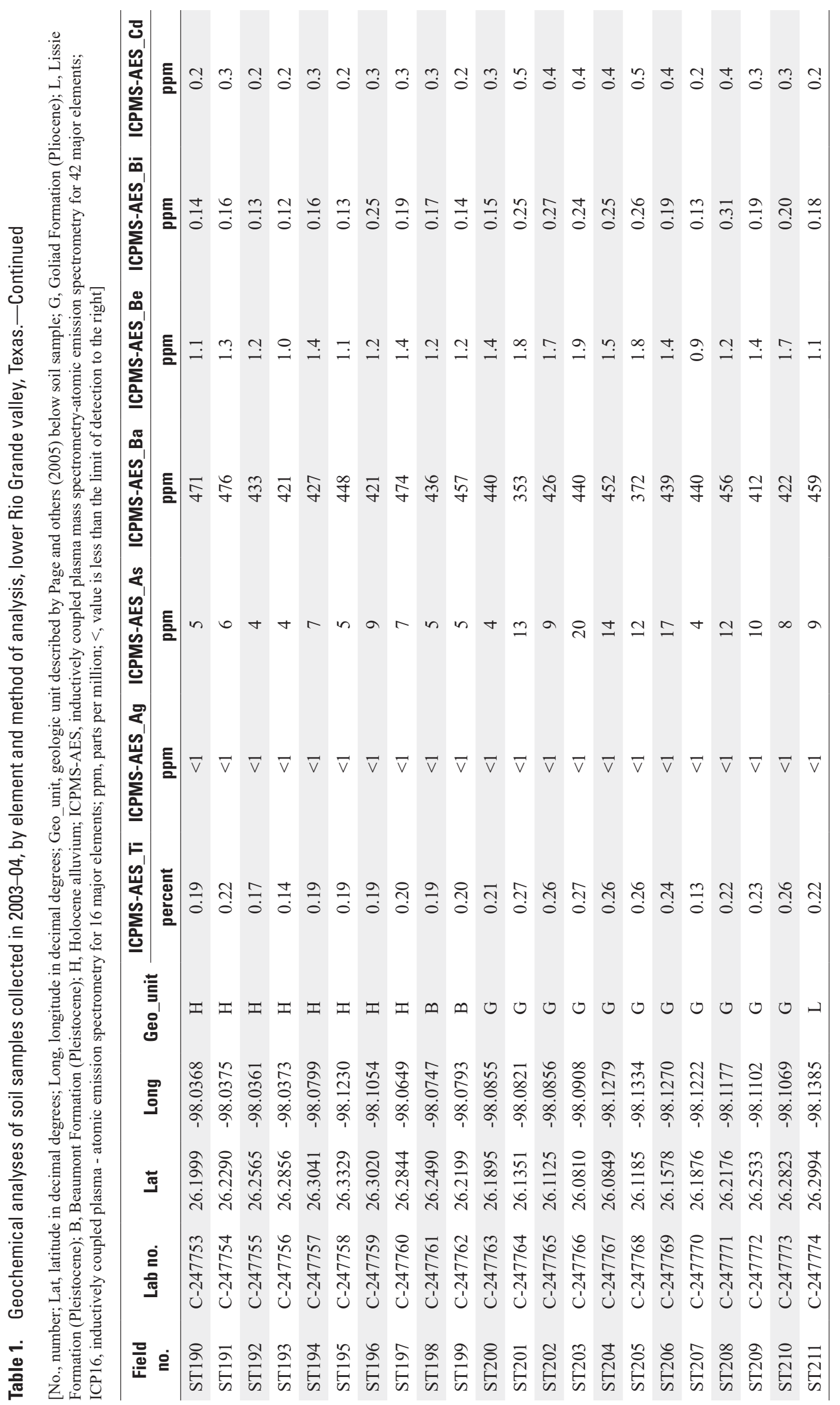




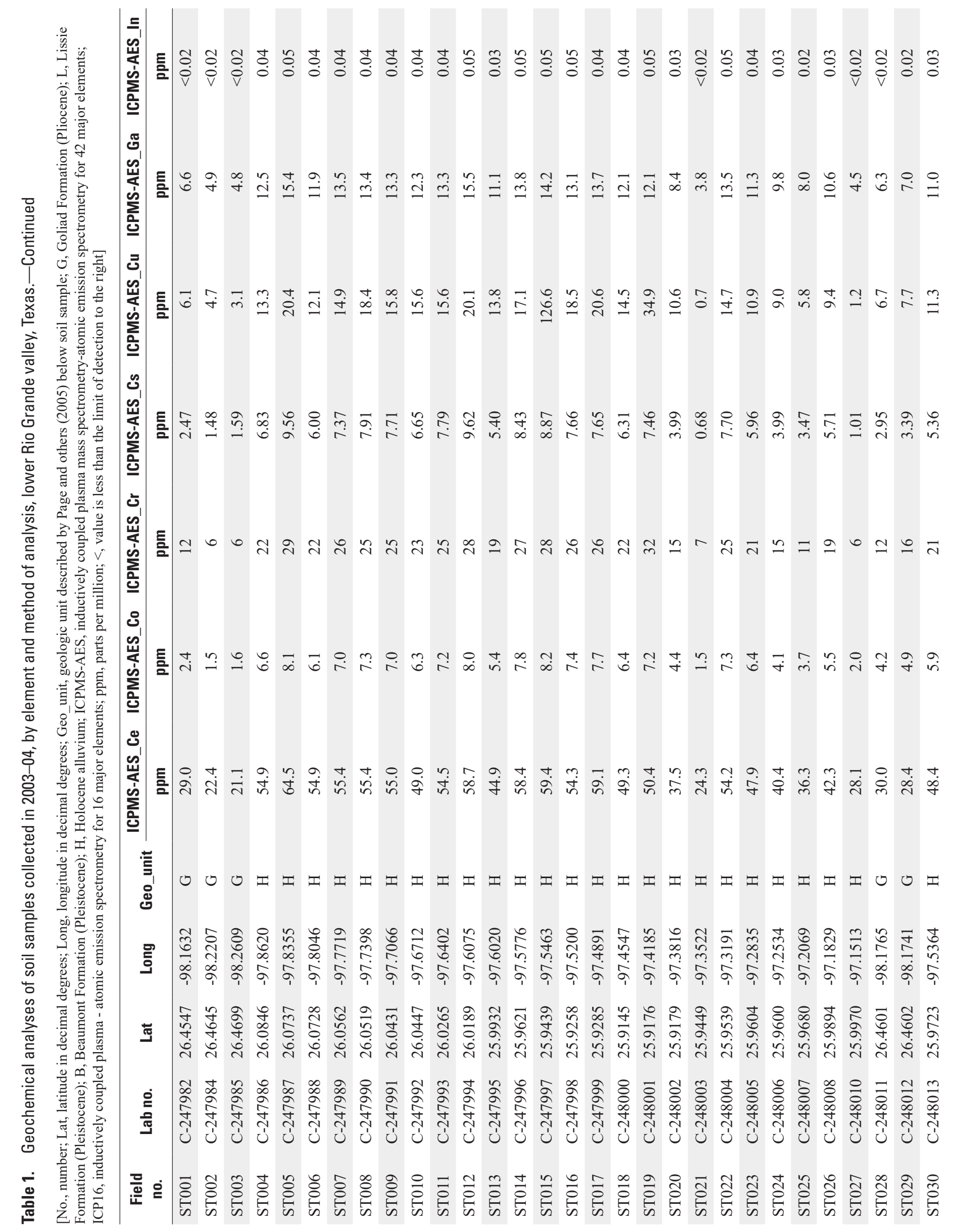




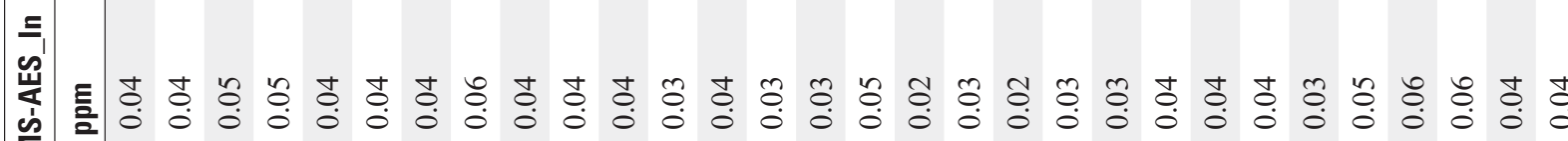
蓆

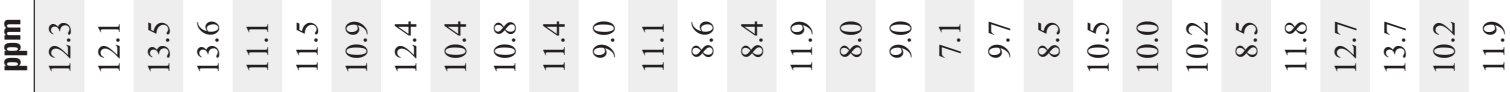

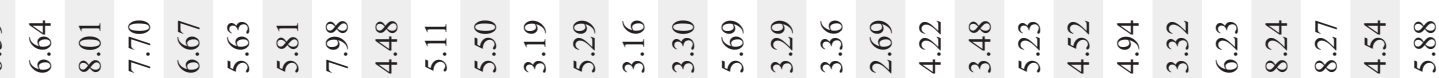

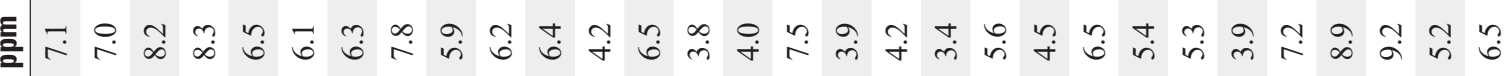




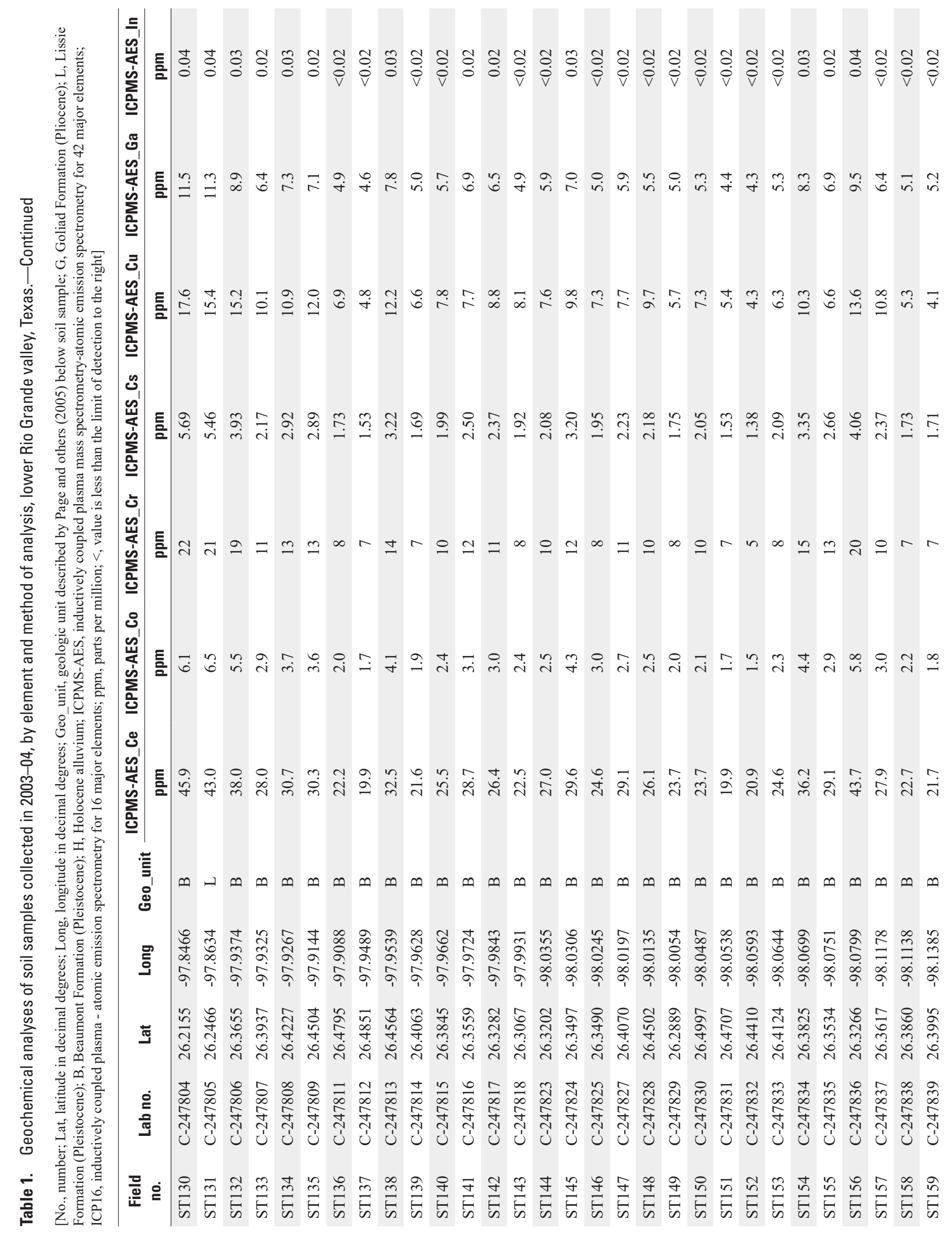




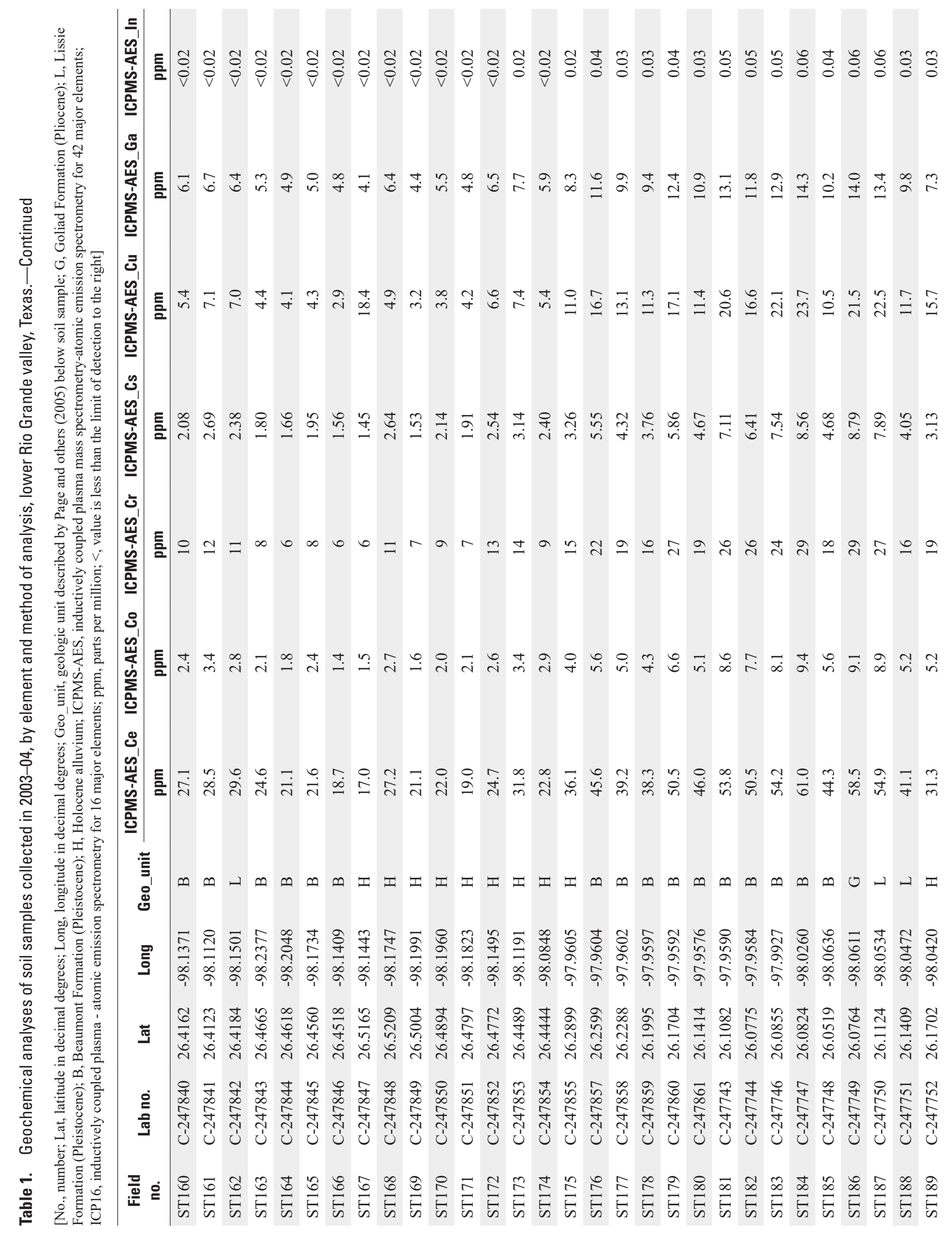




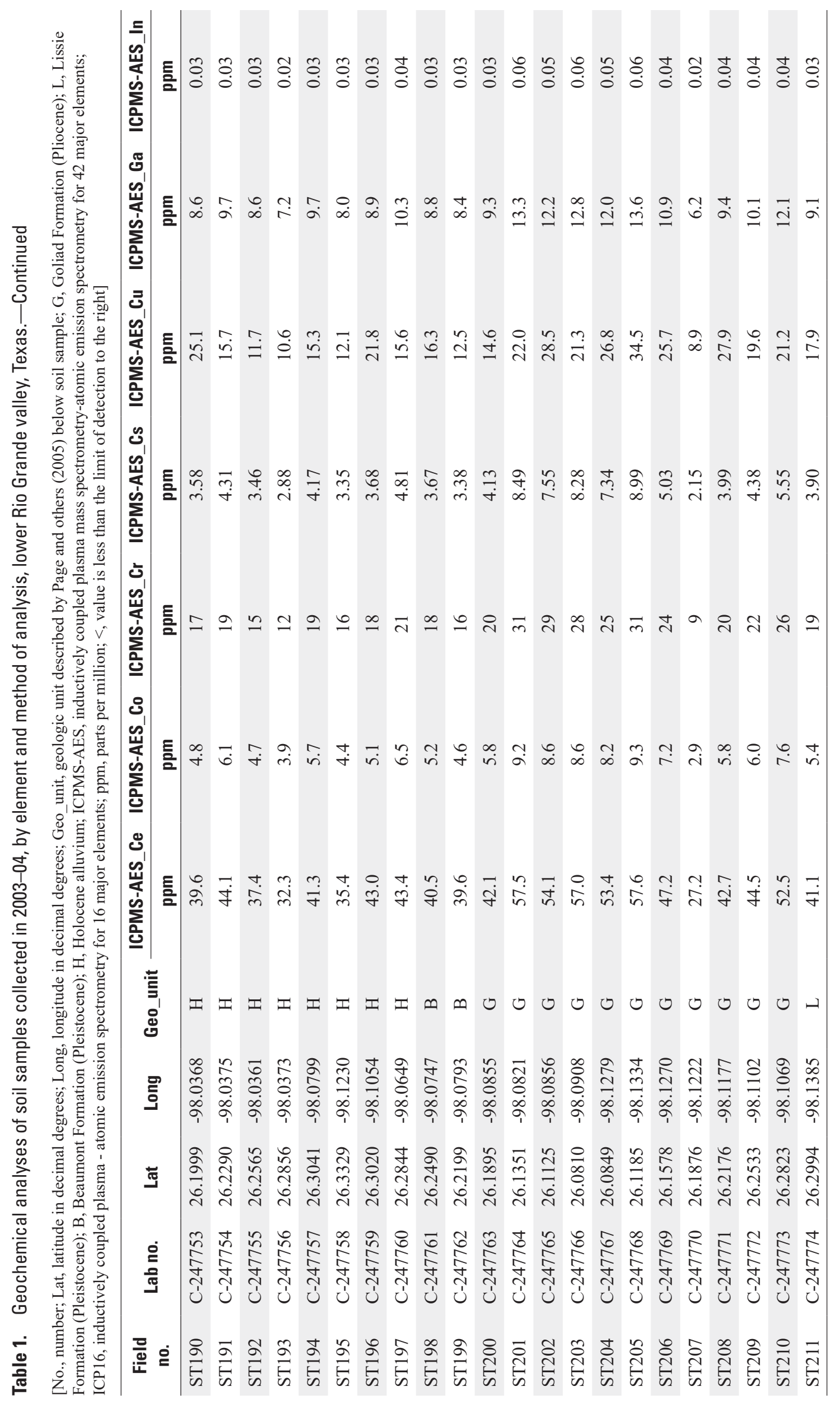




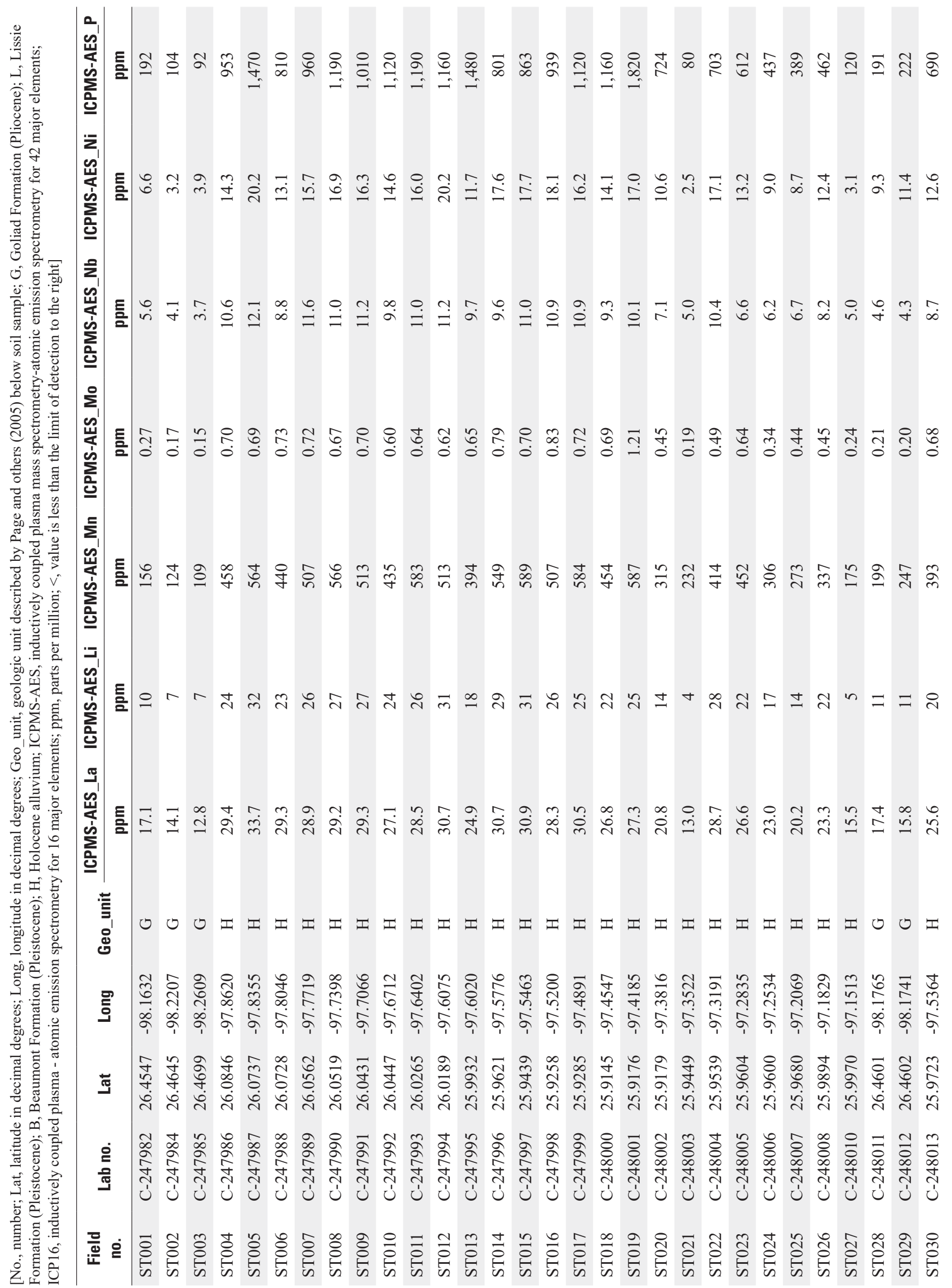




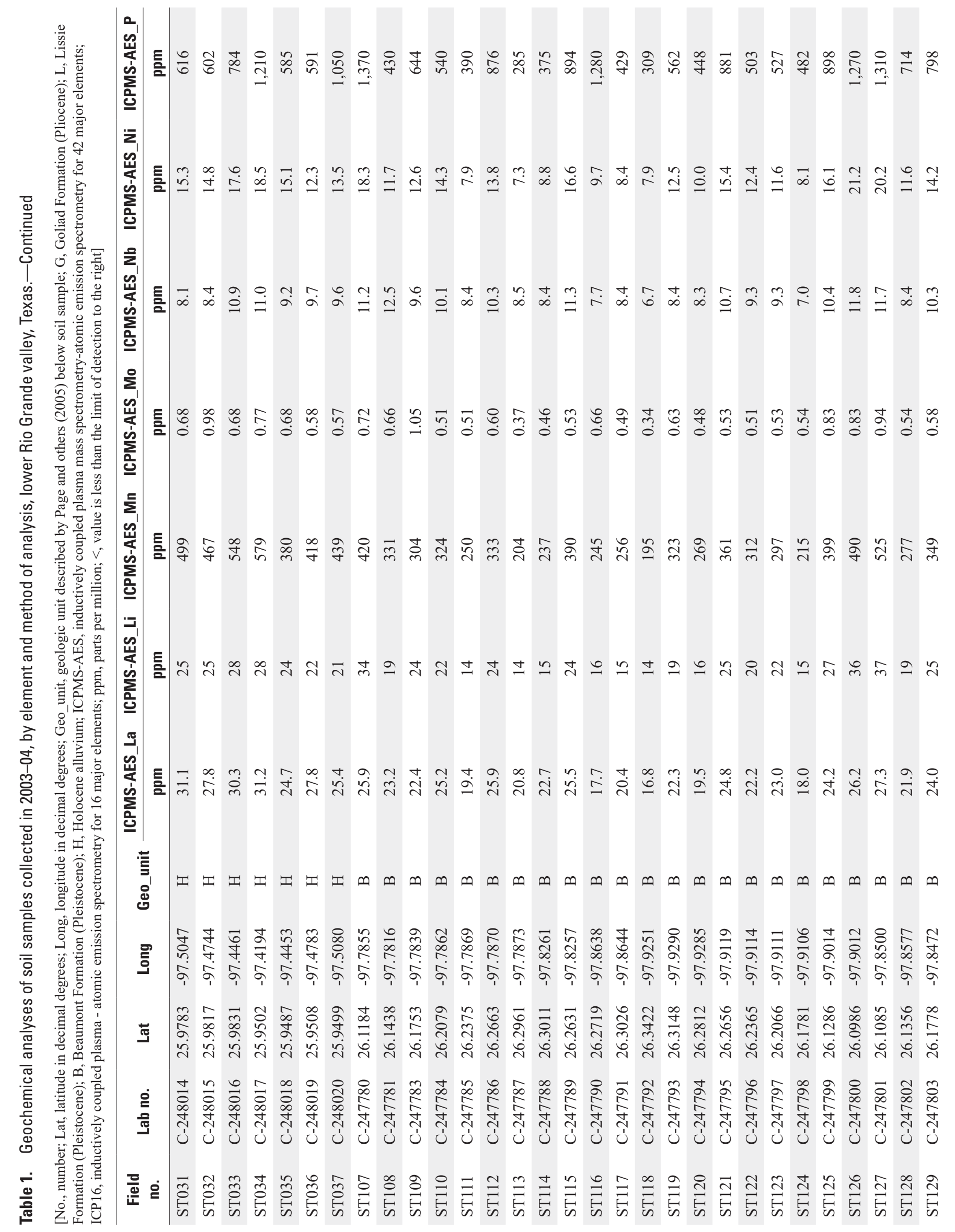




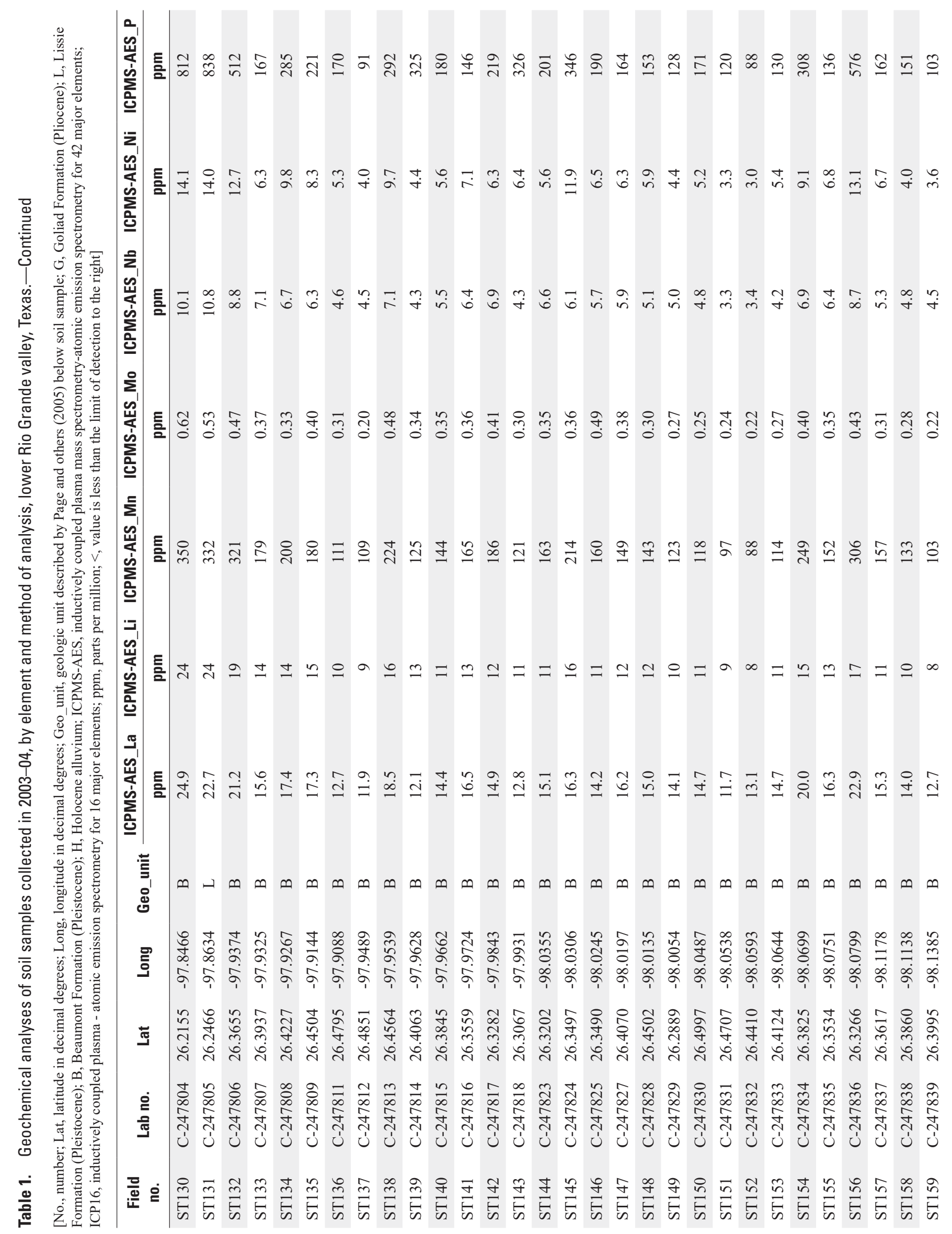




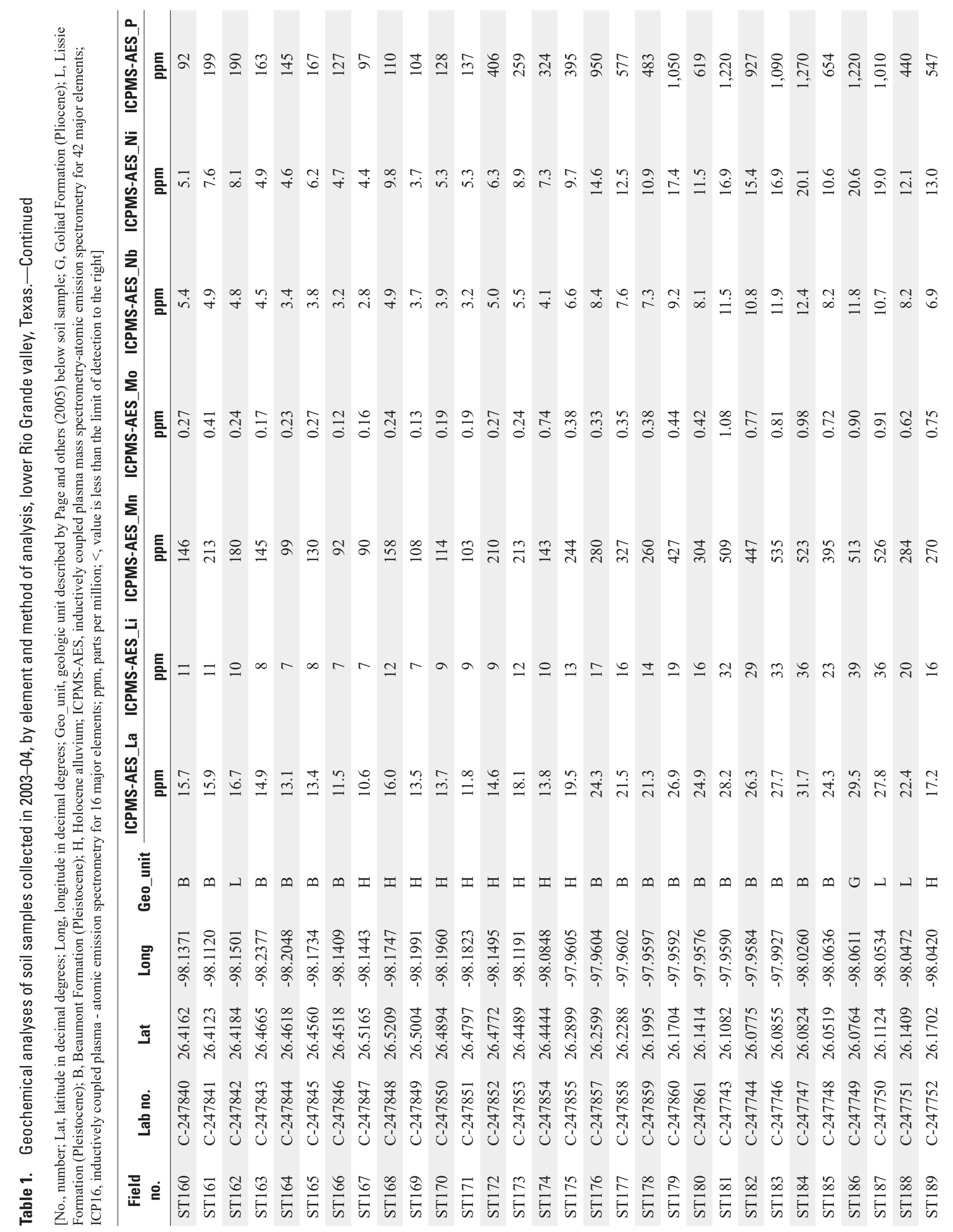




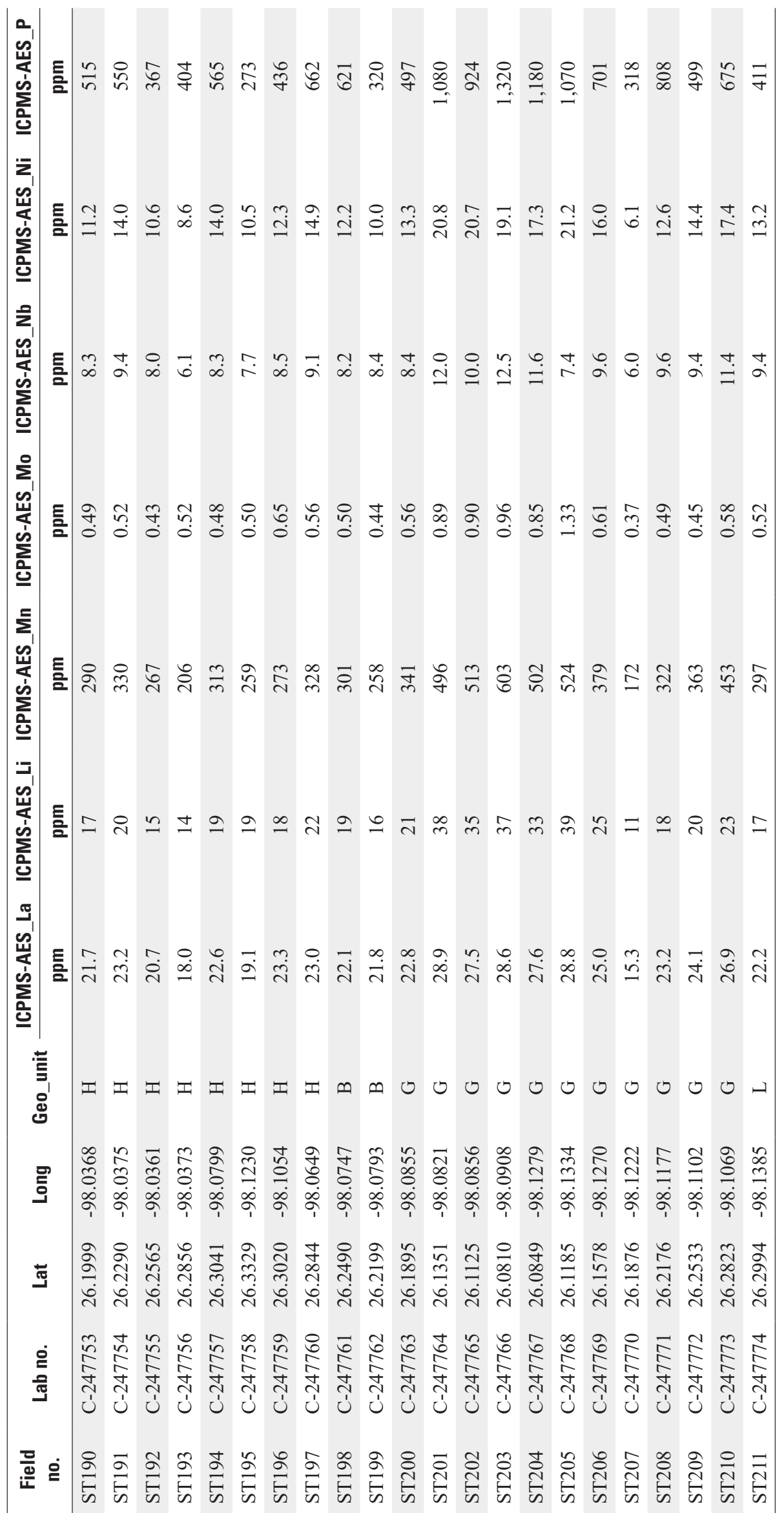




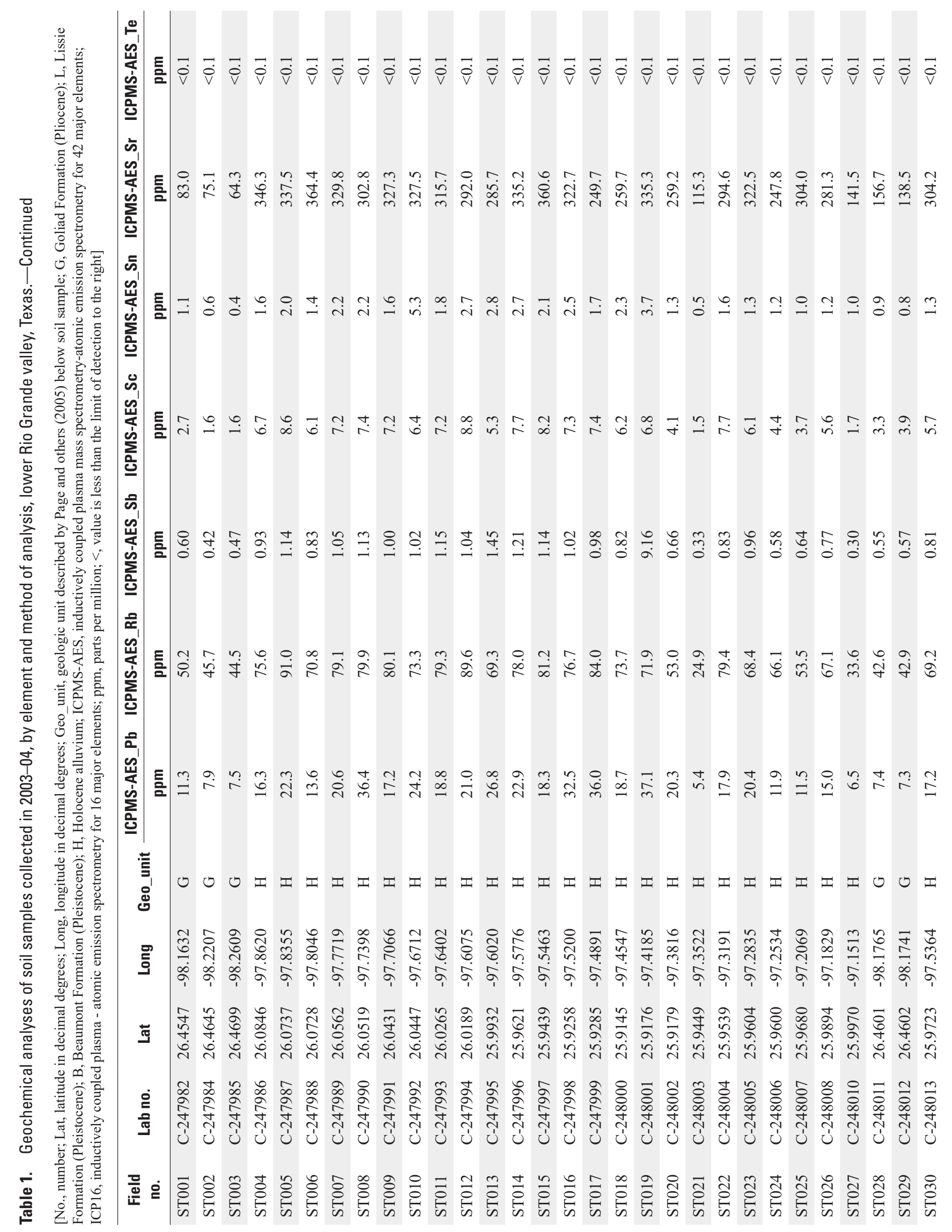




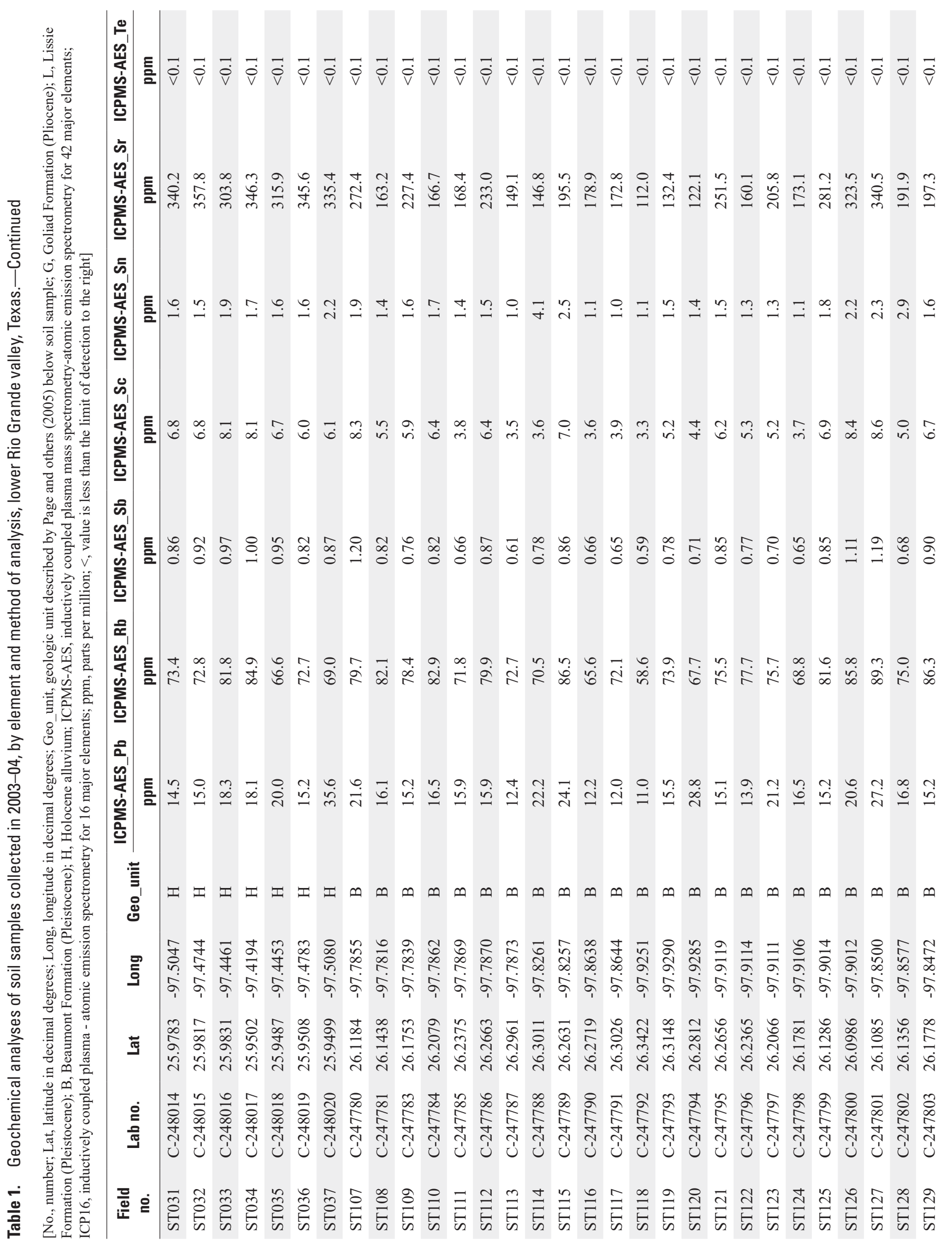




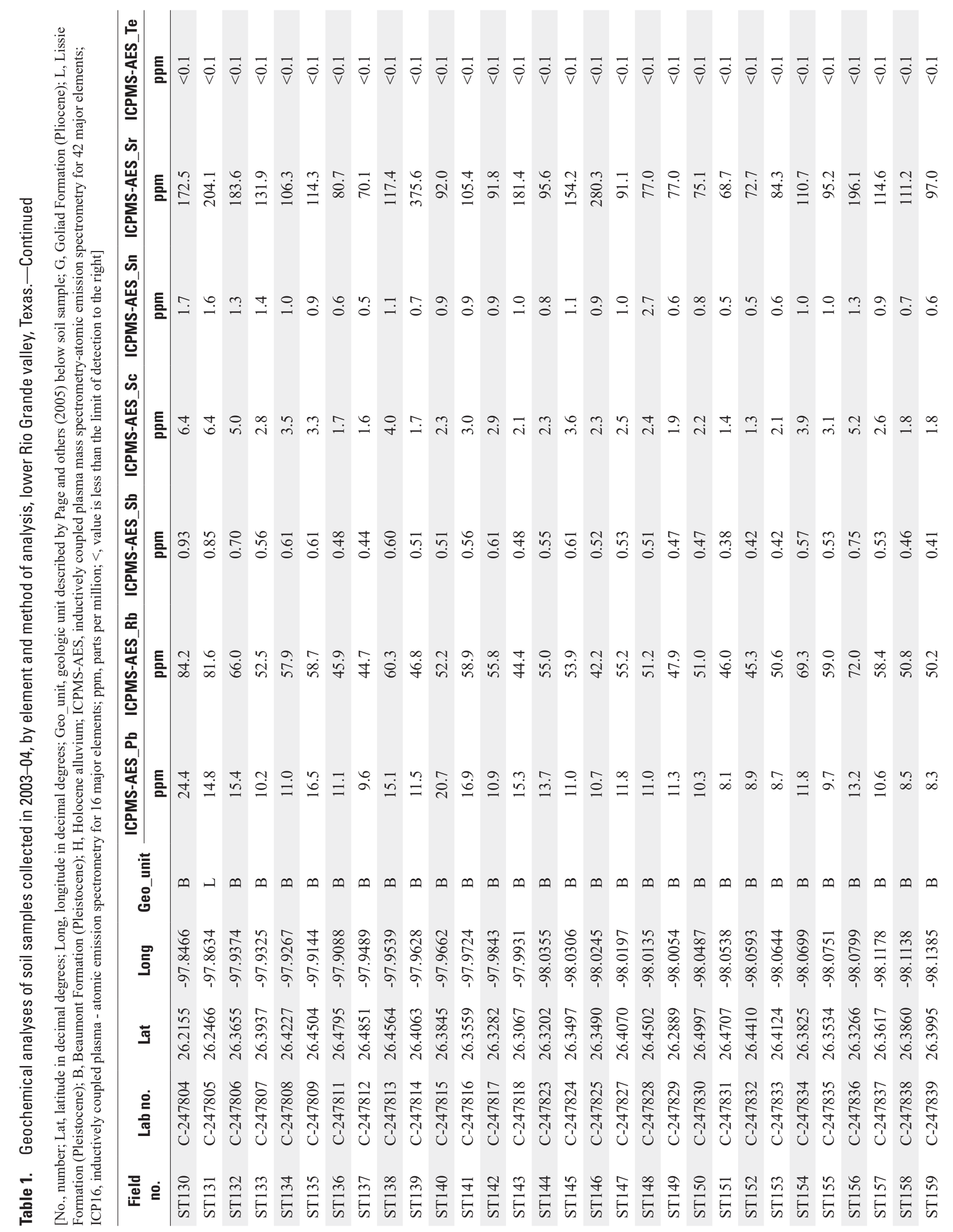




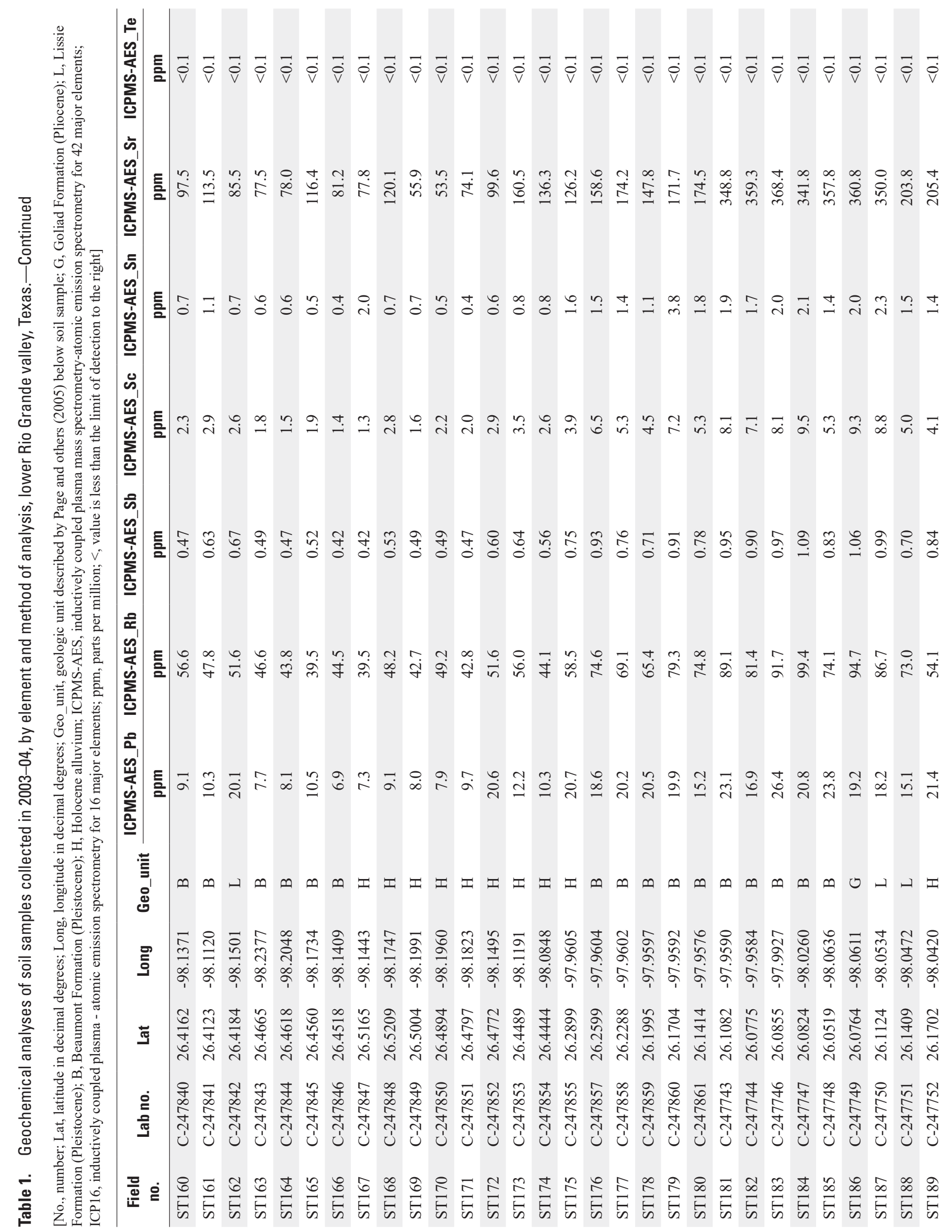




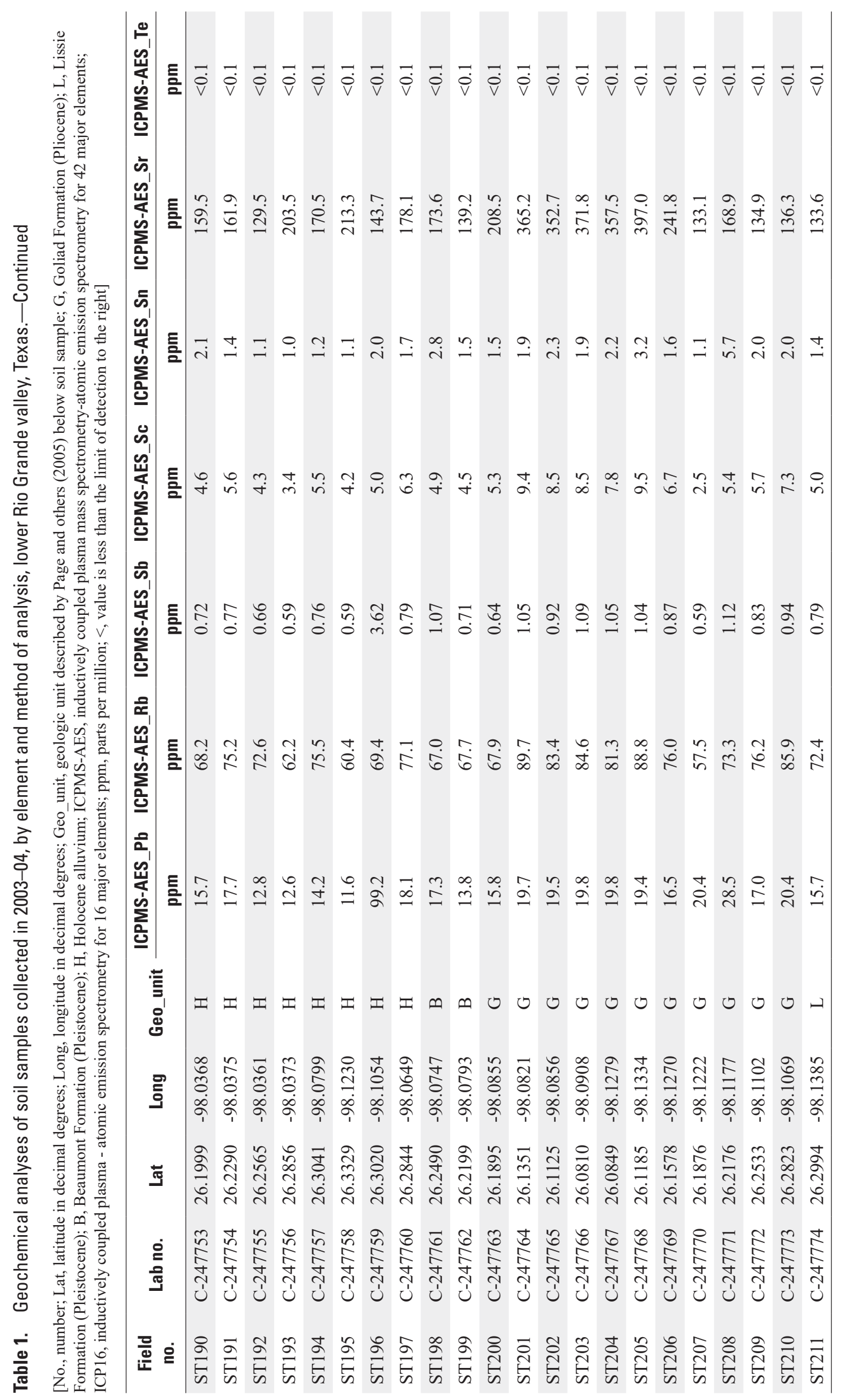




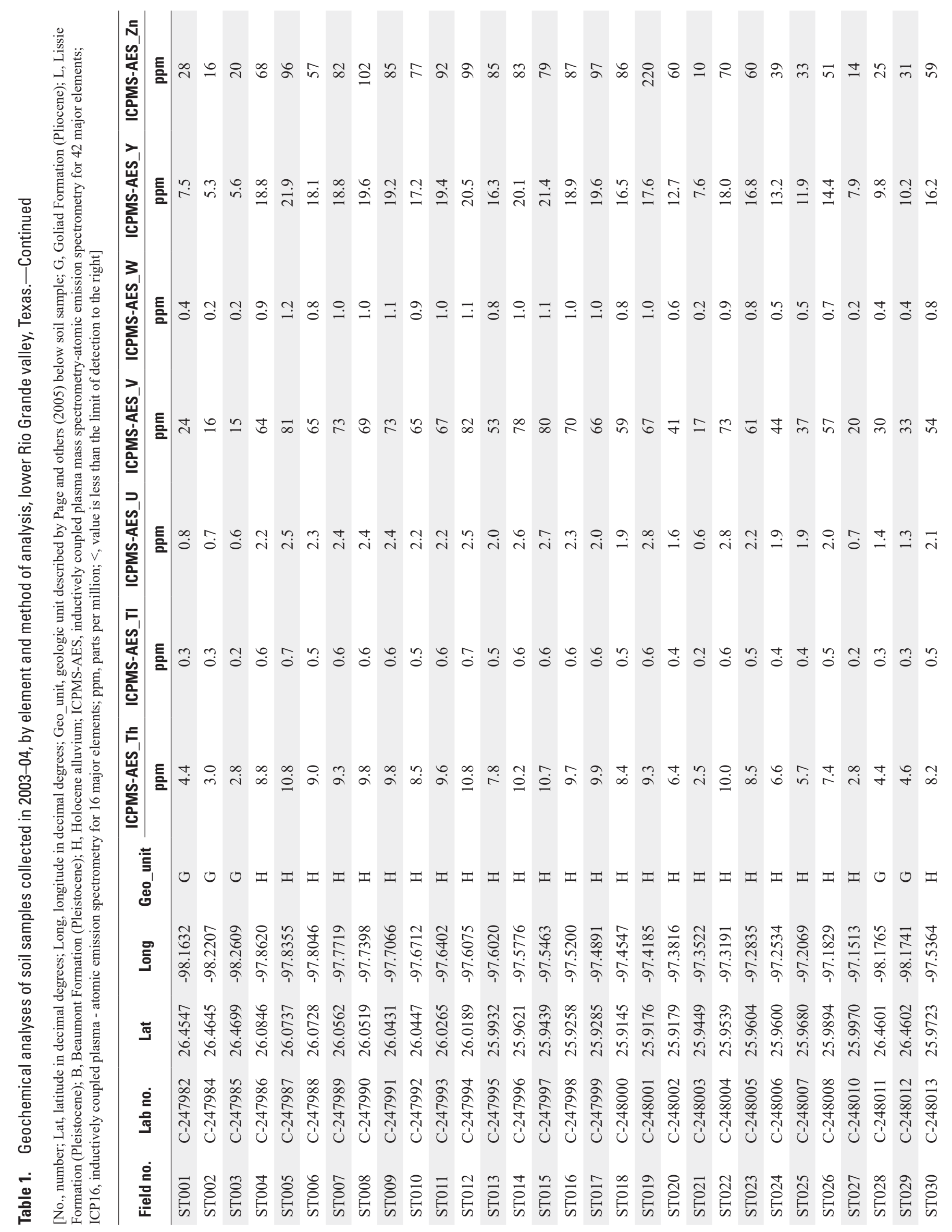




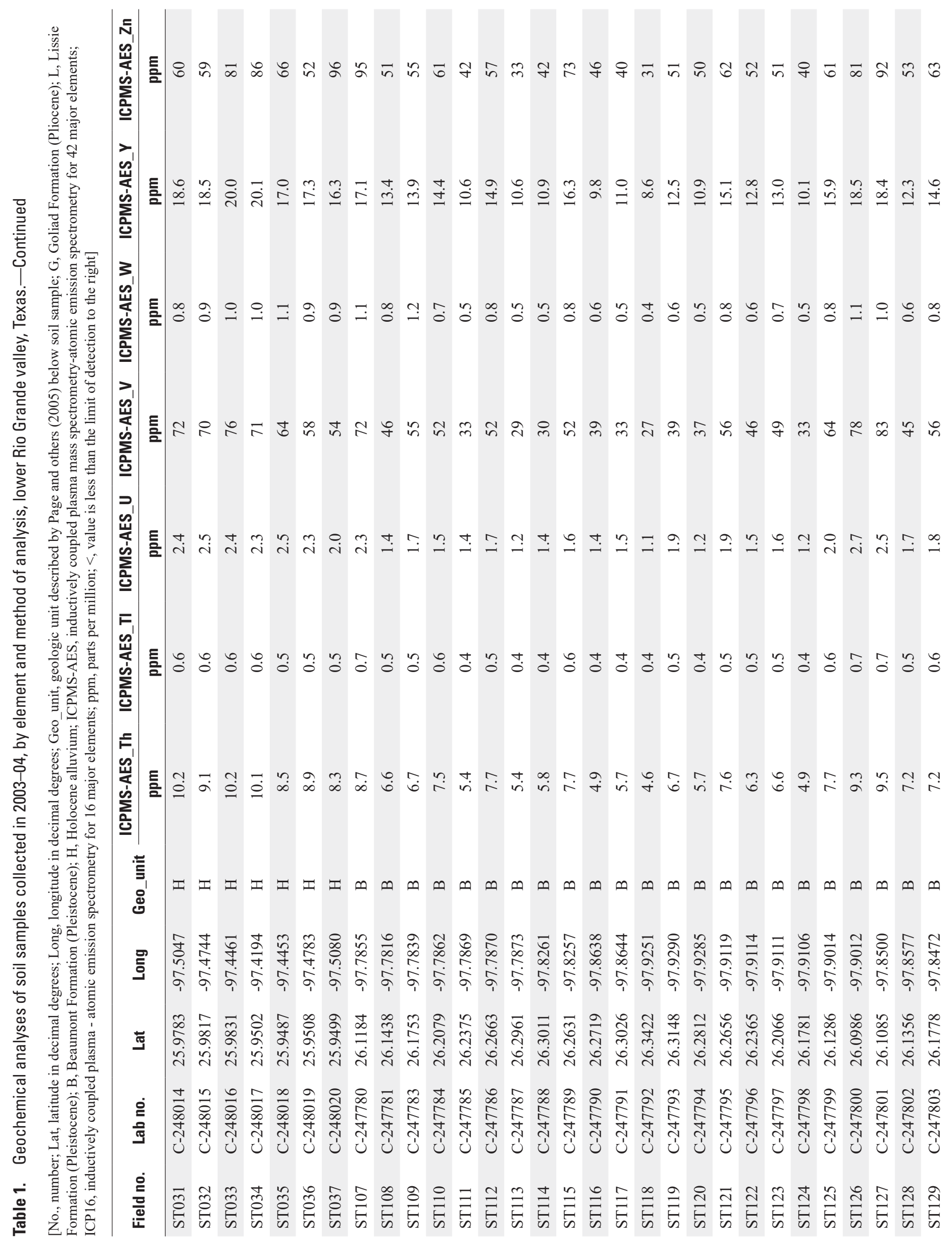




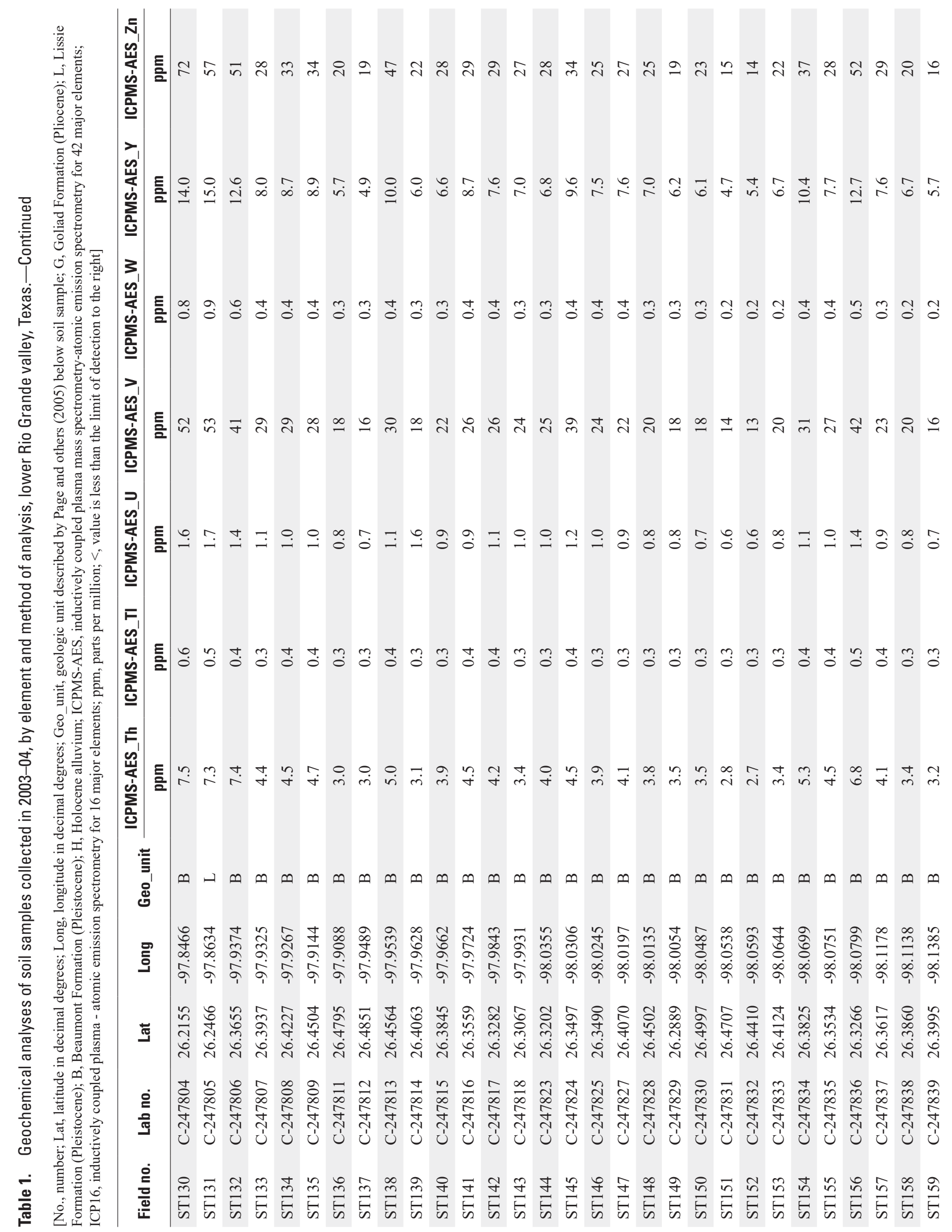




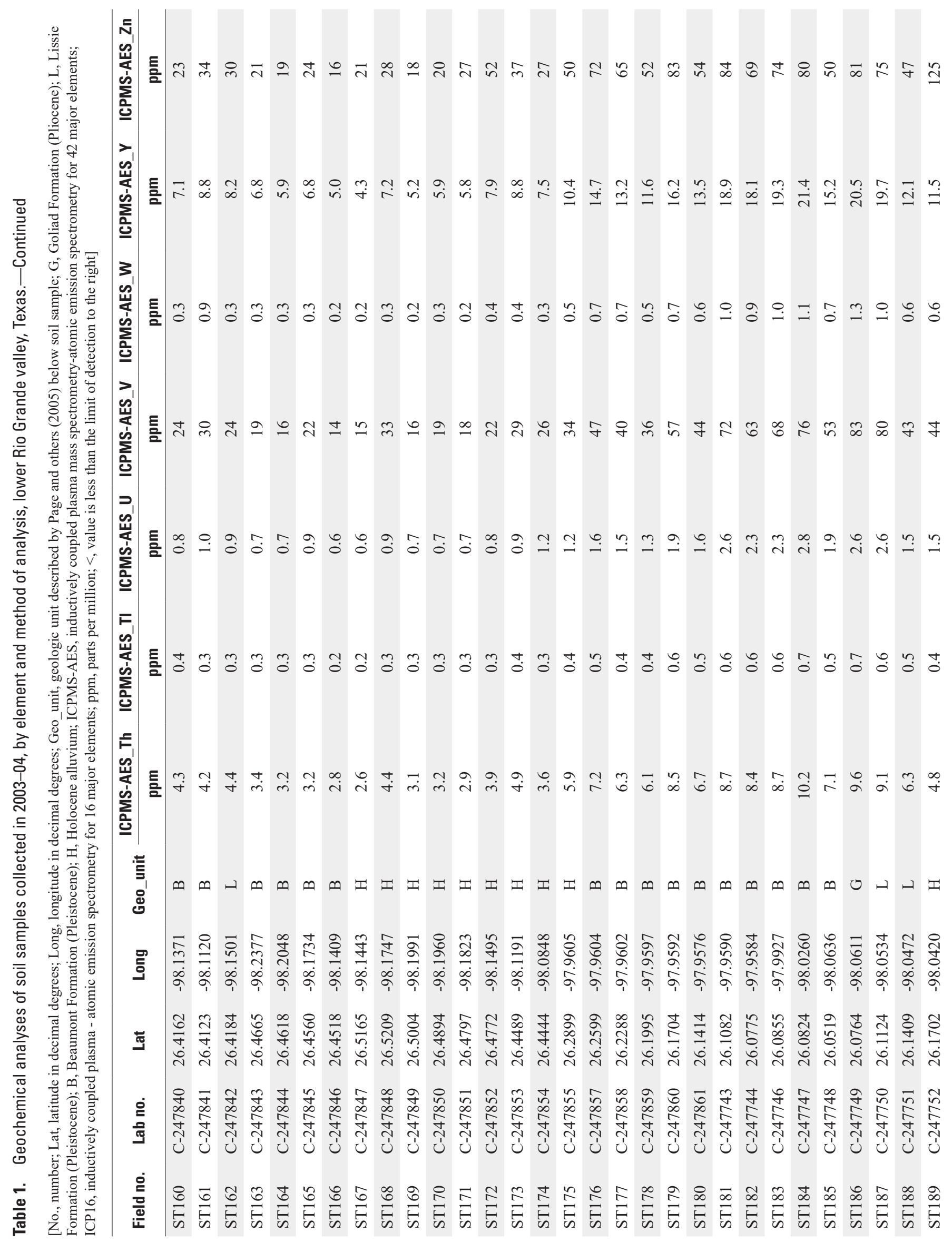




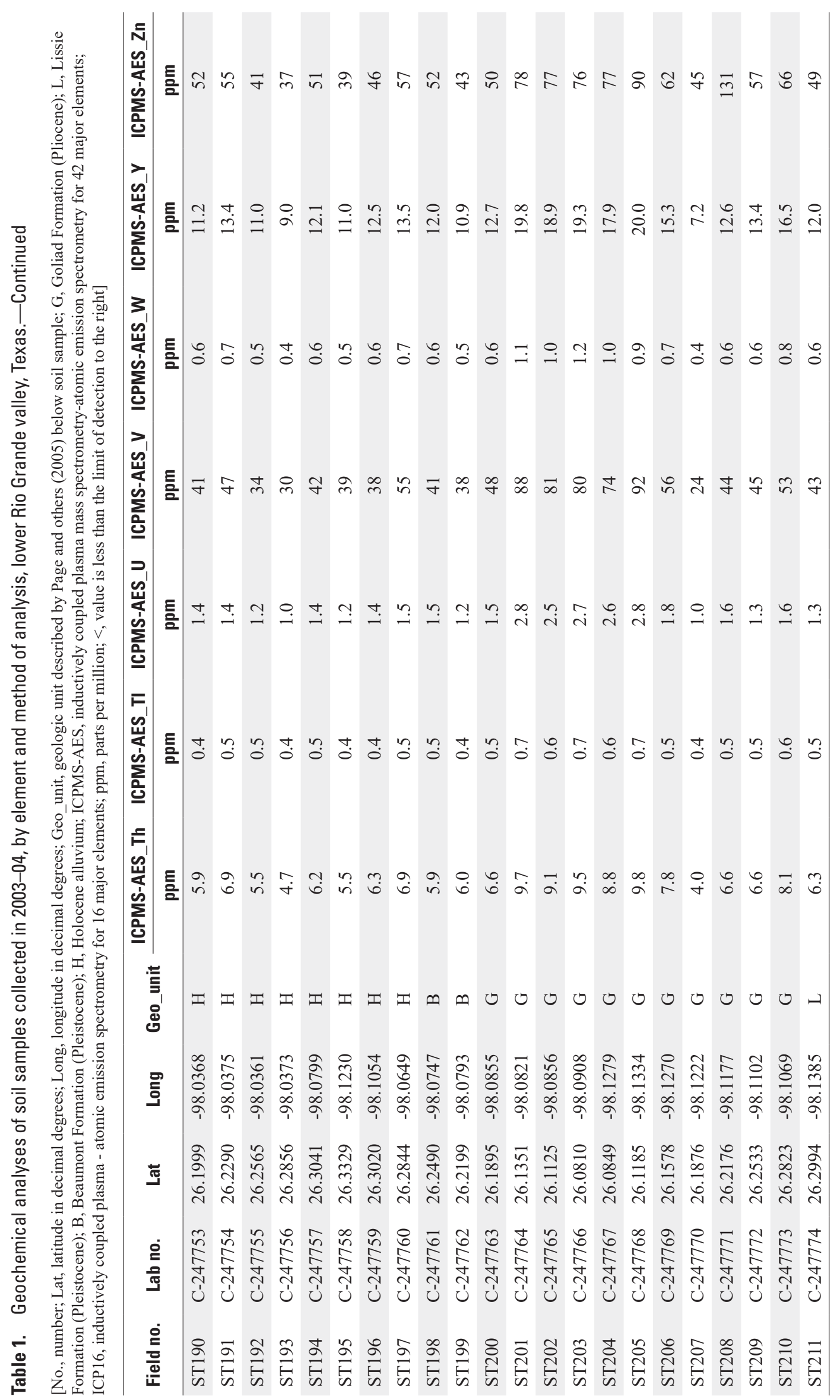




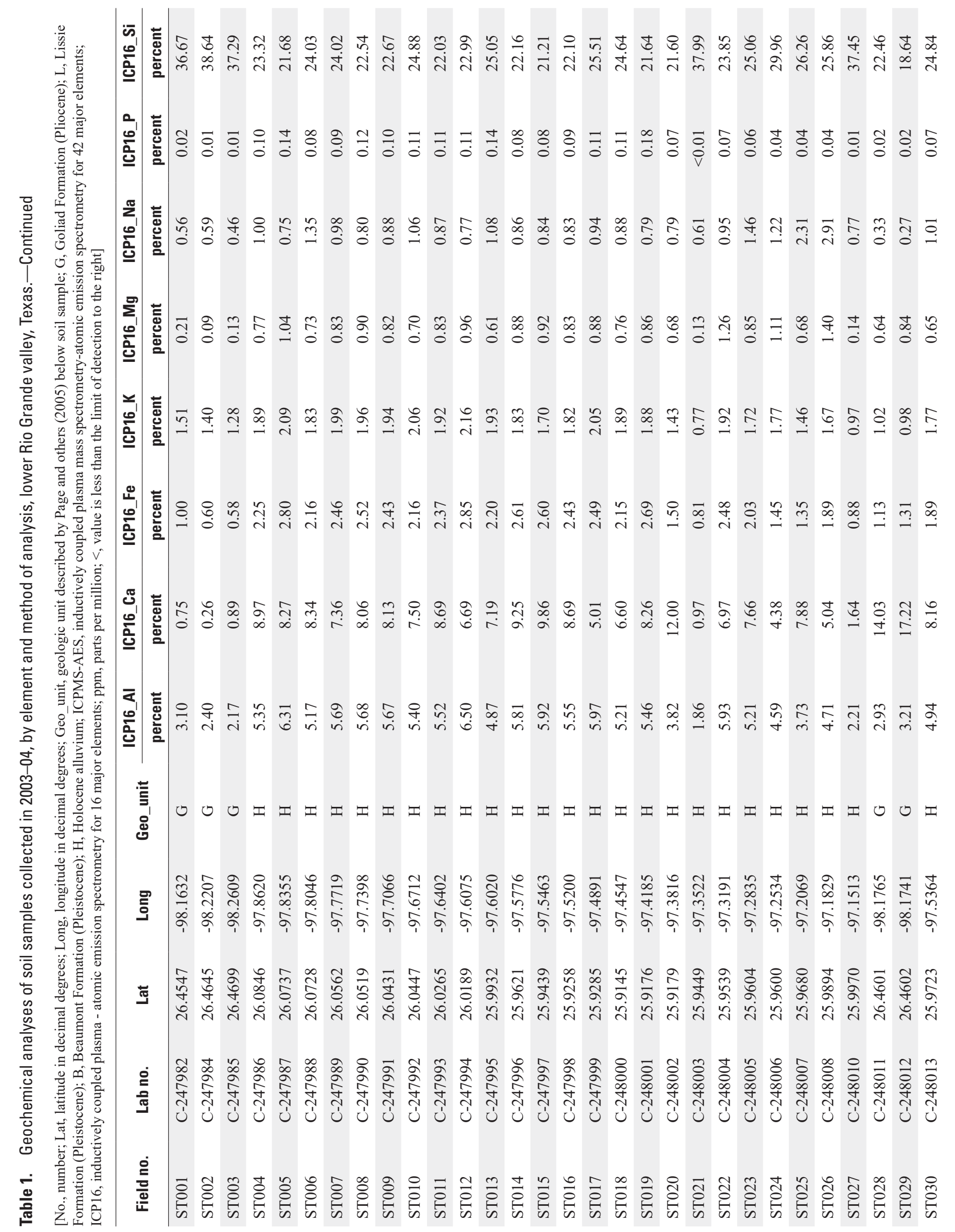




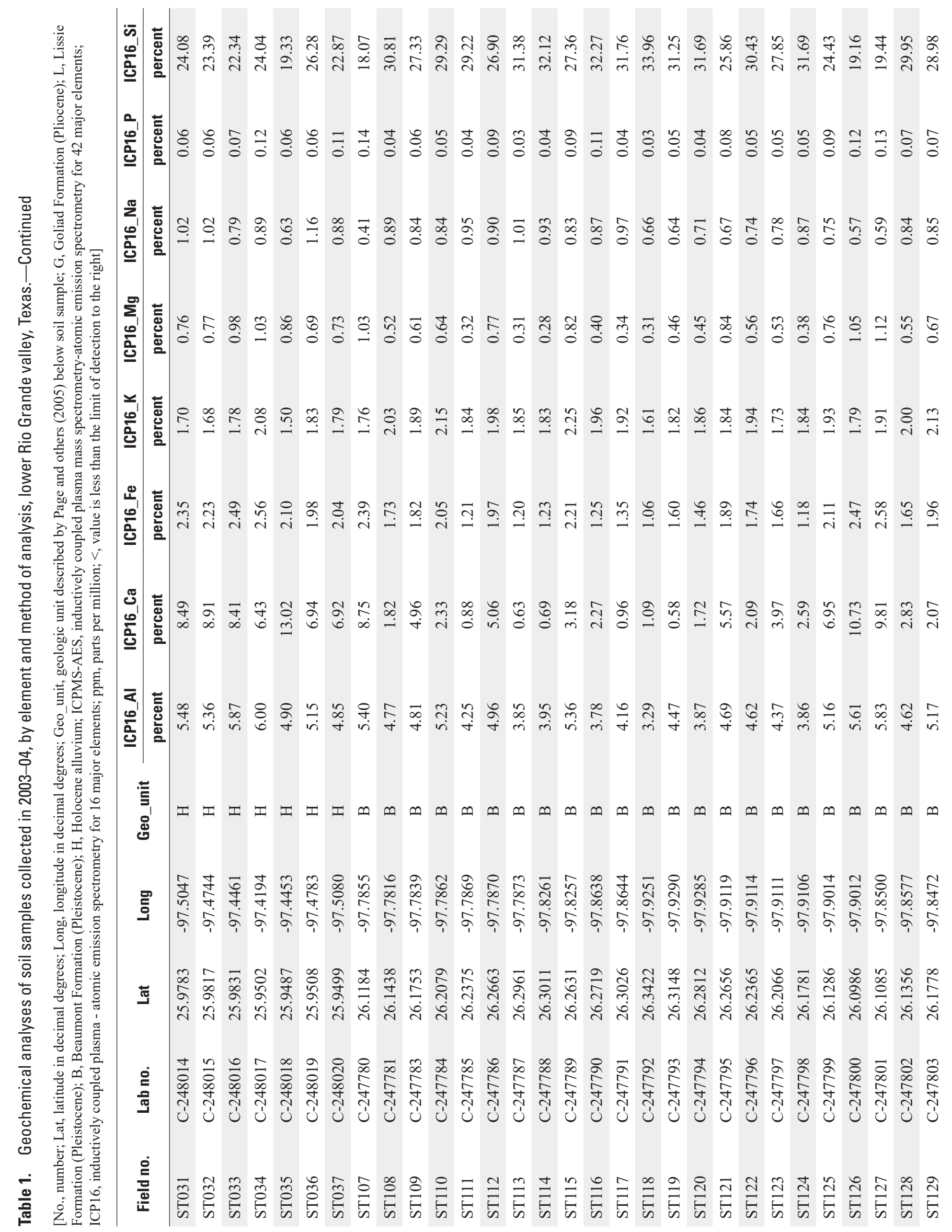




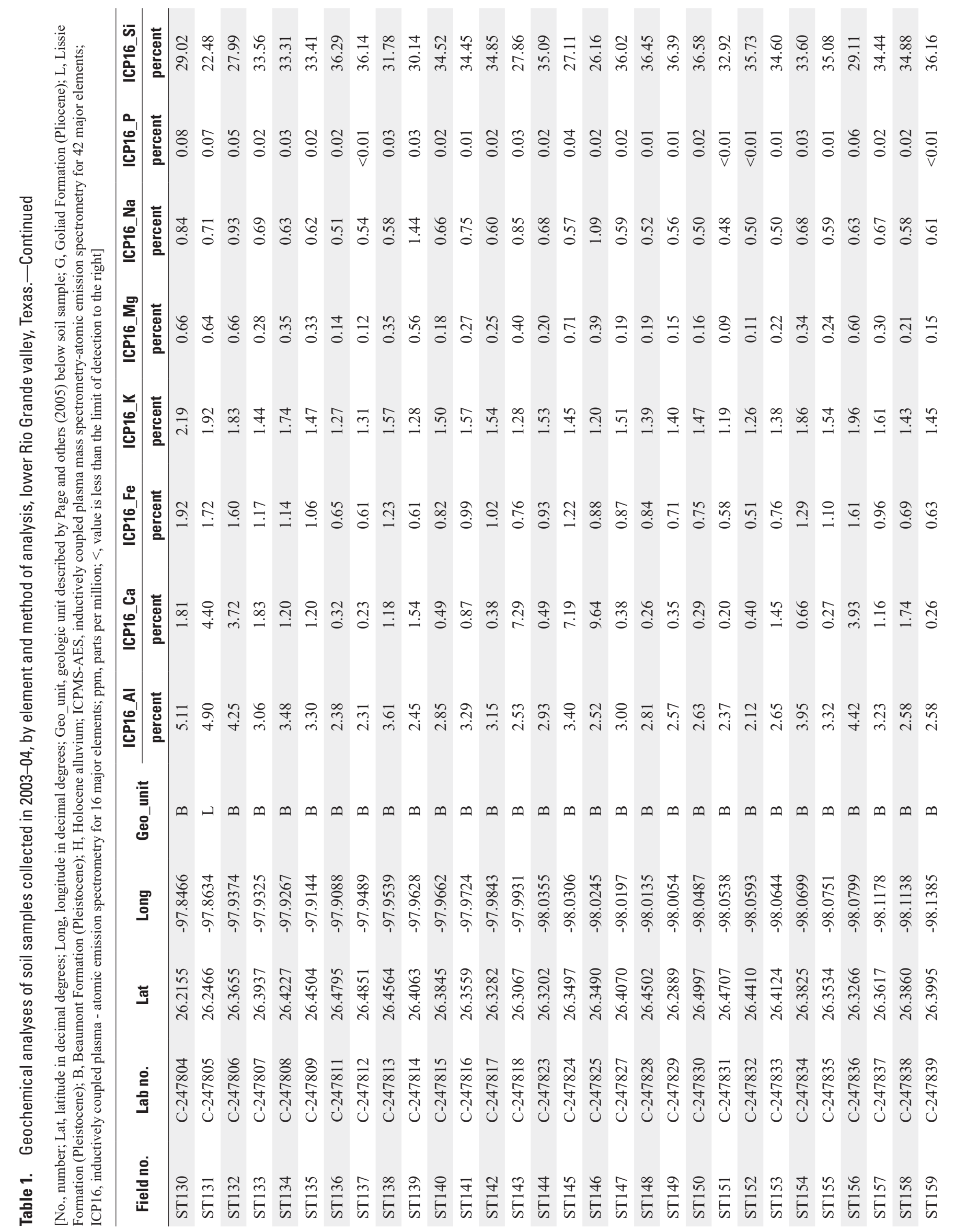




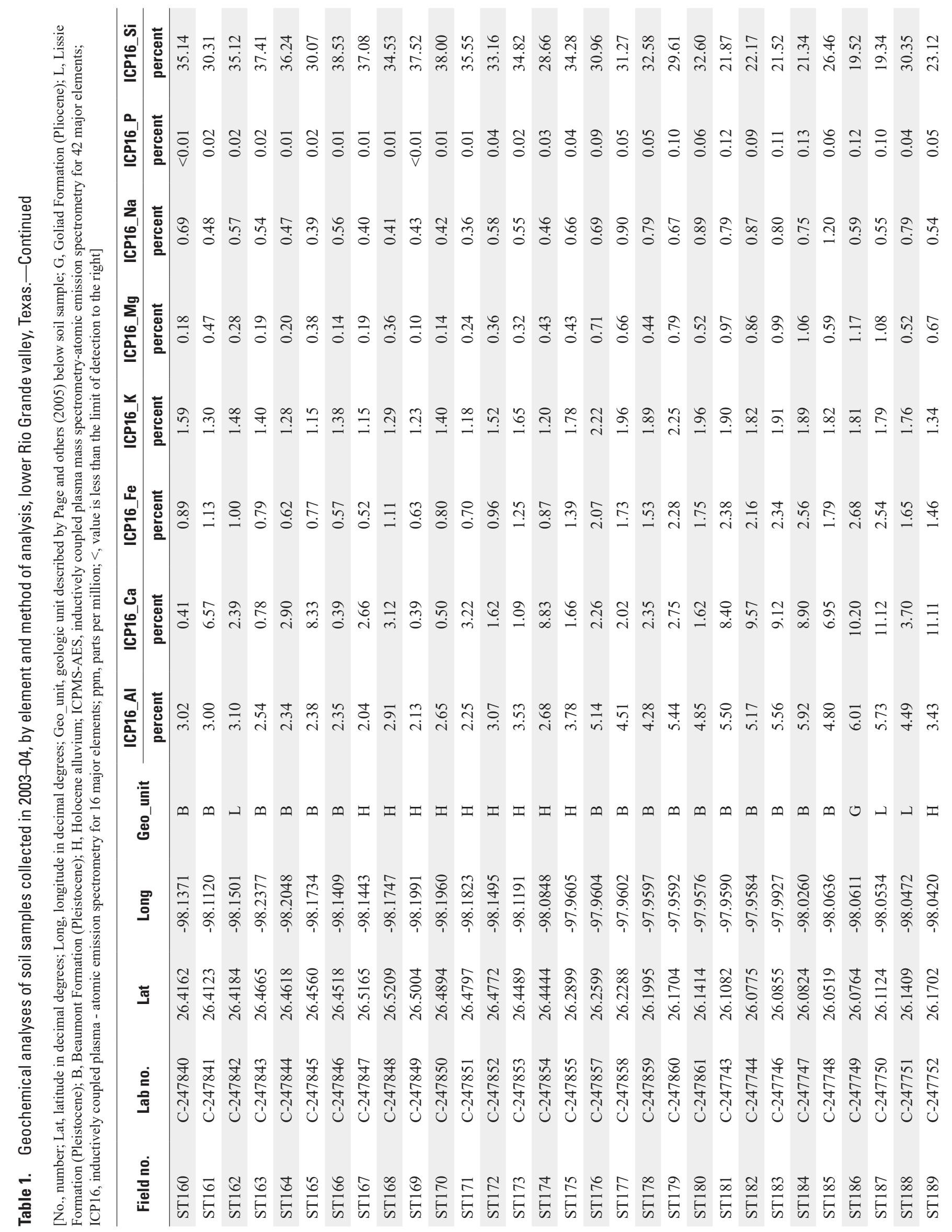




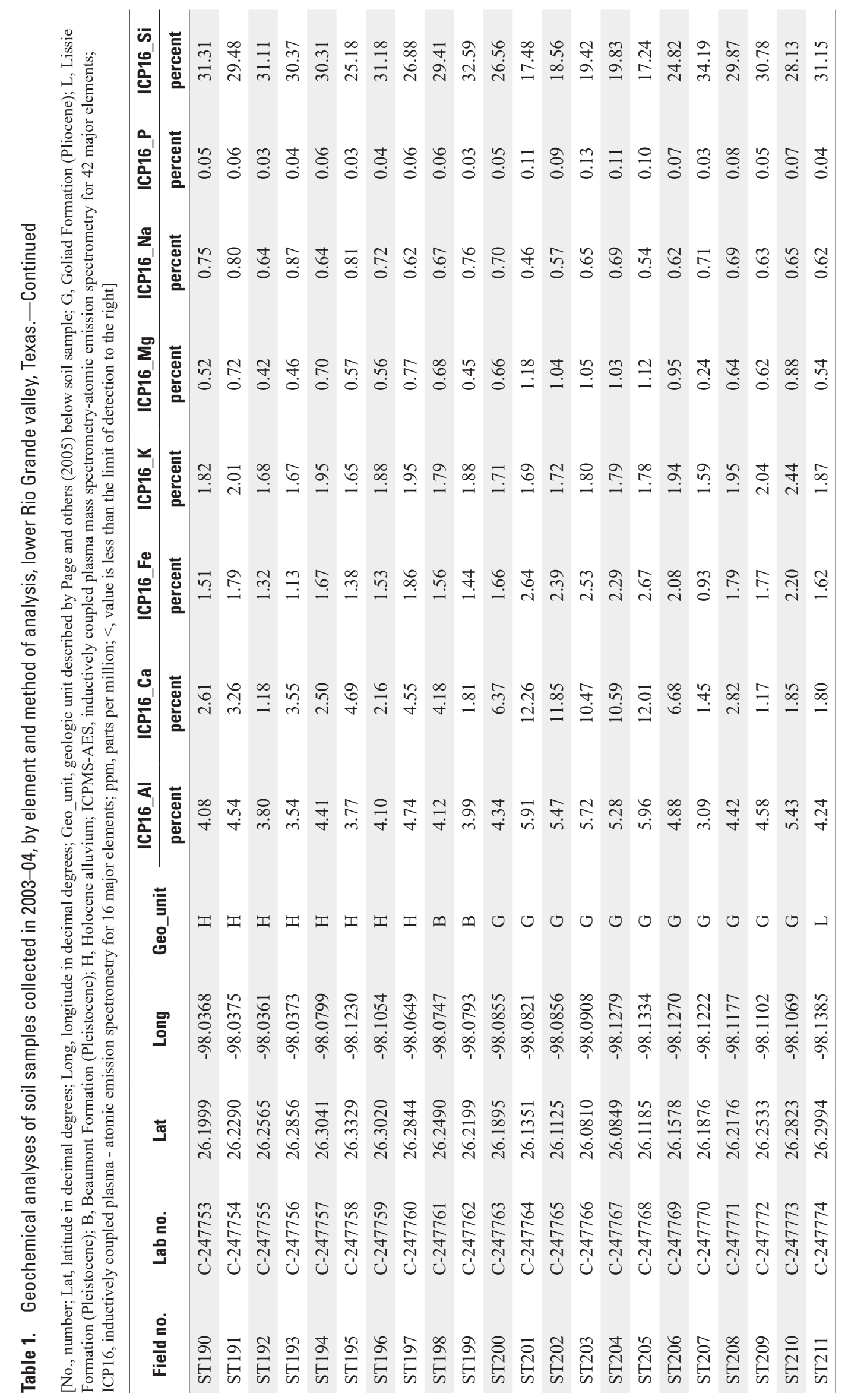




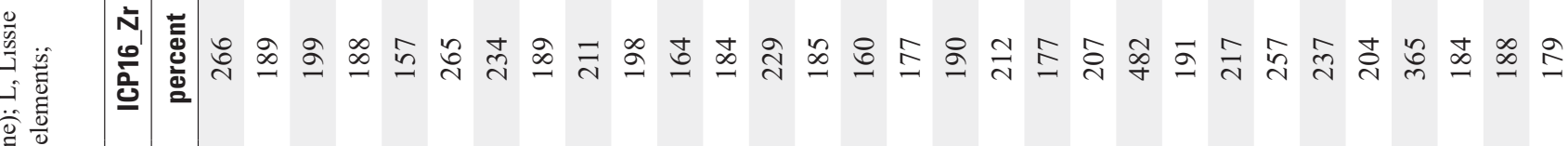

竞

㐫 .

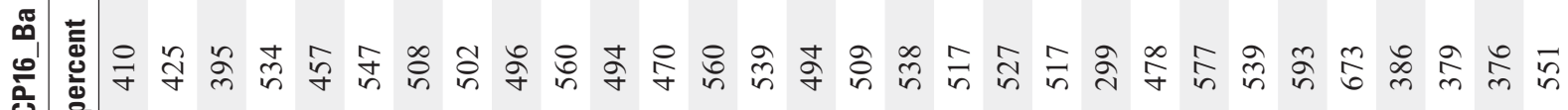
J.

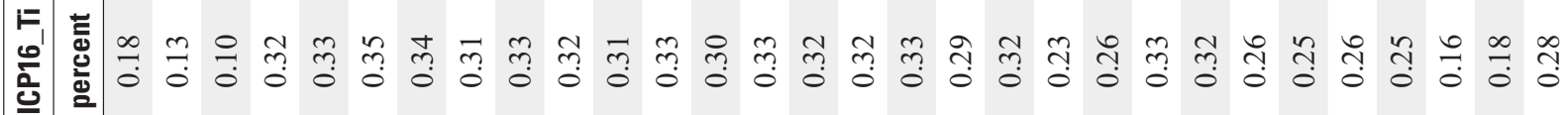

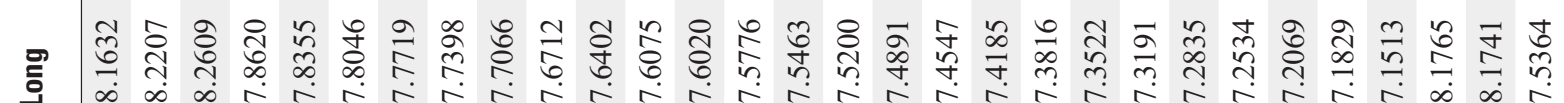
ป d

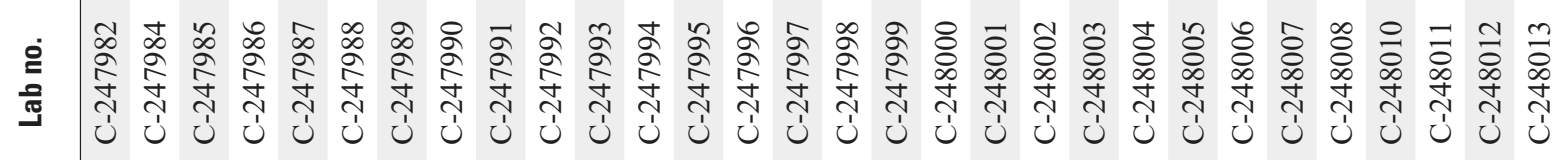

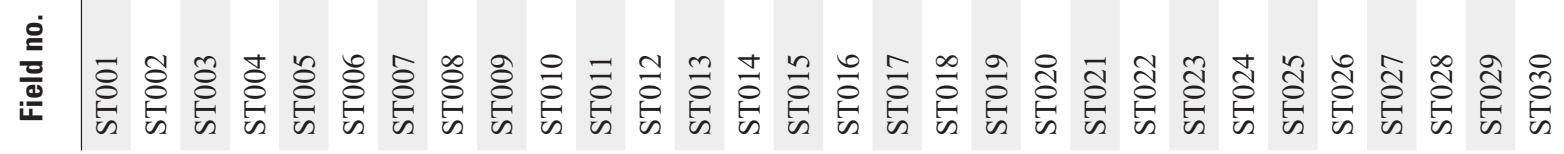




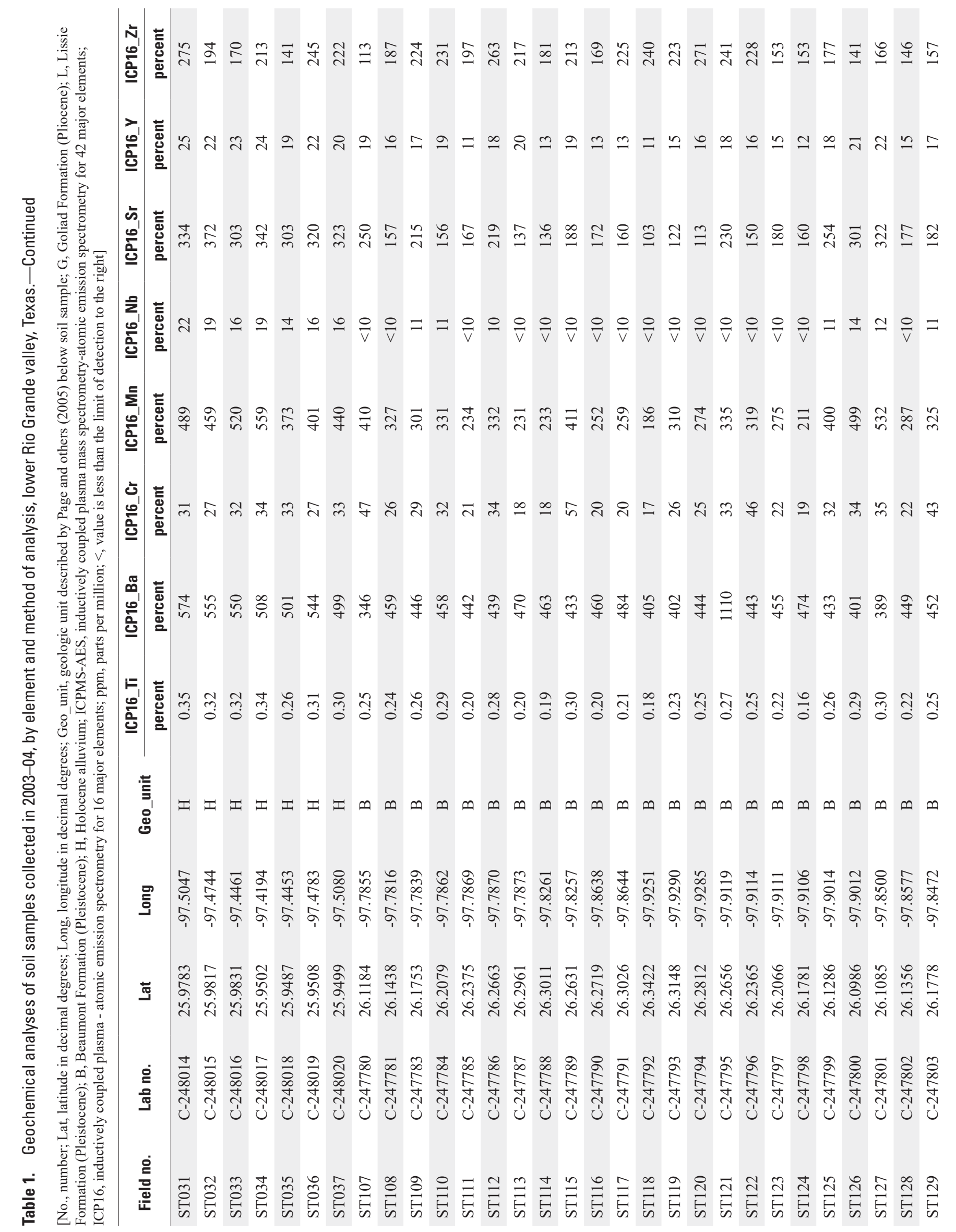




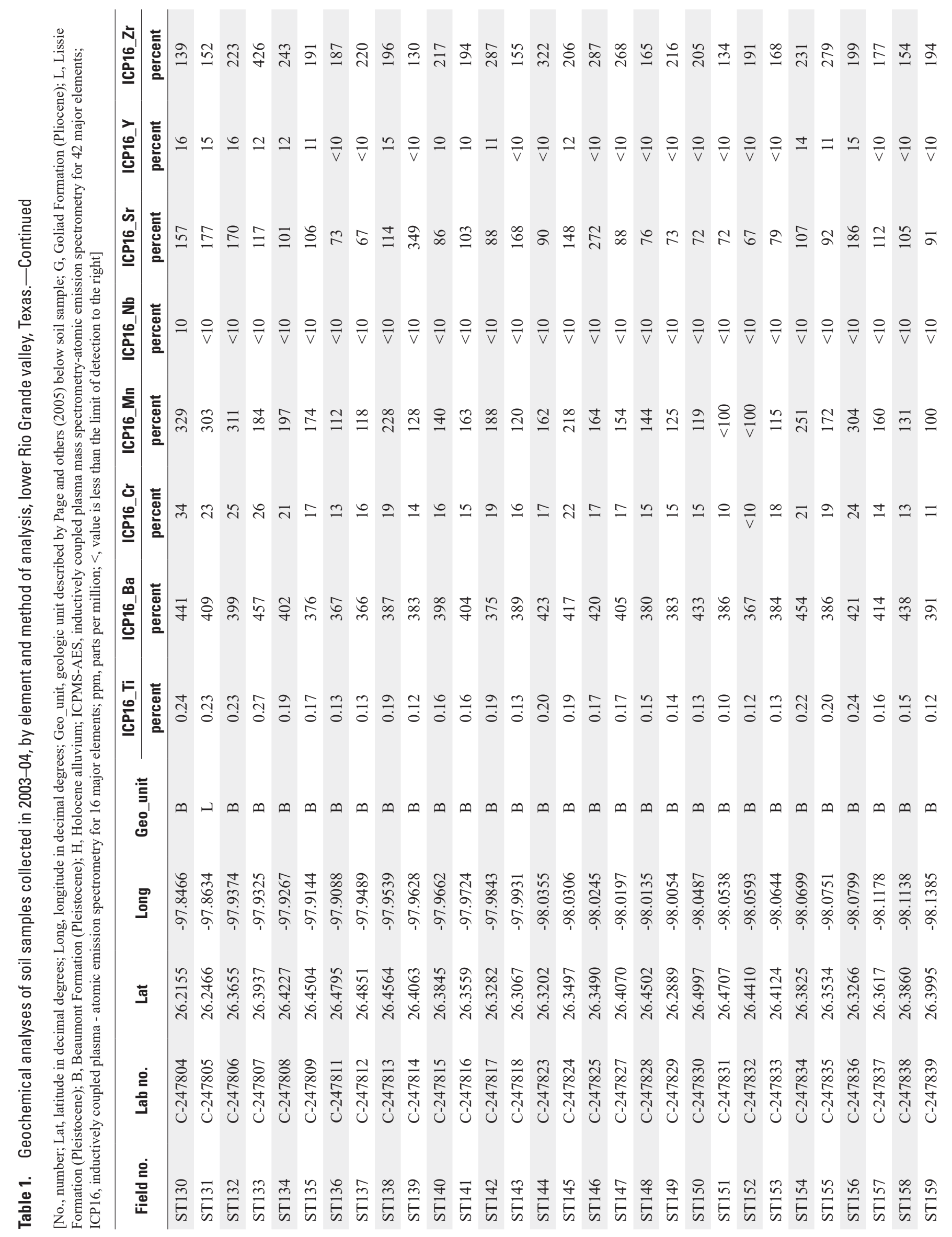




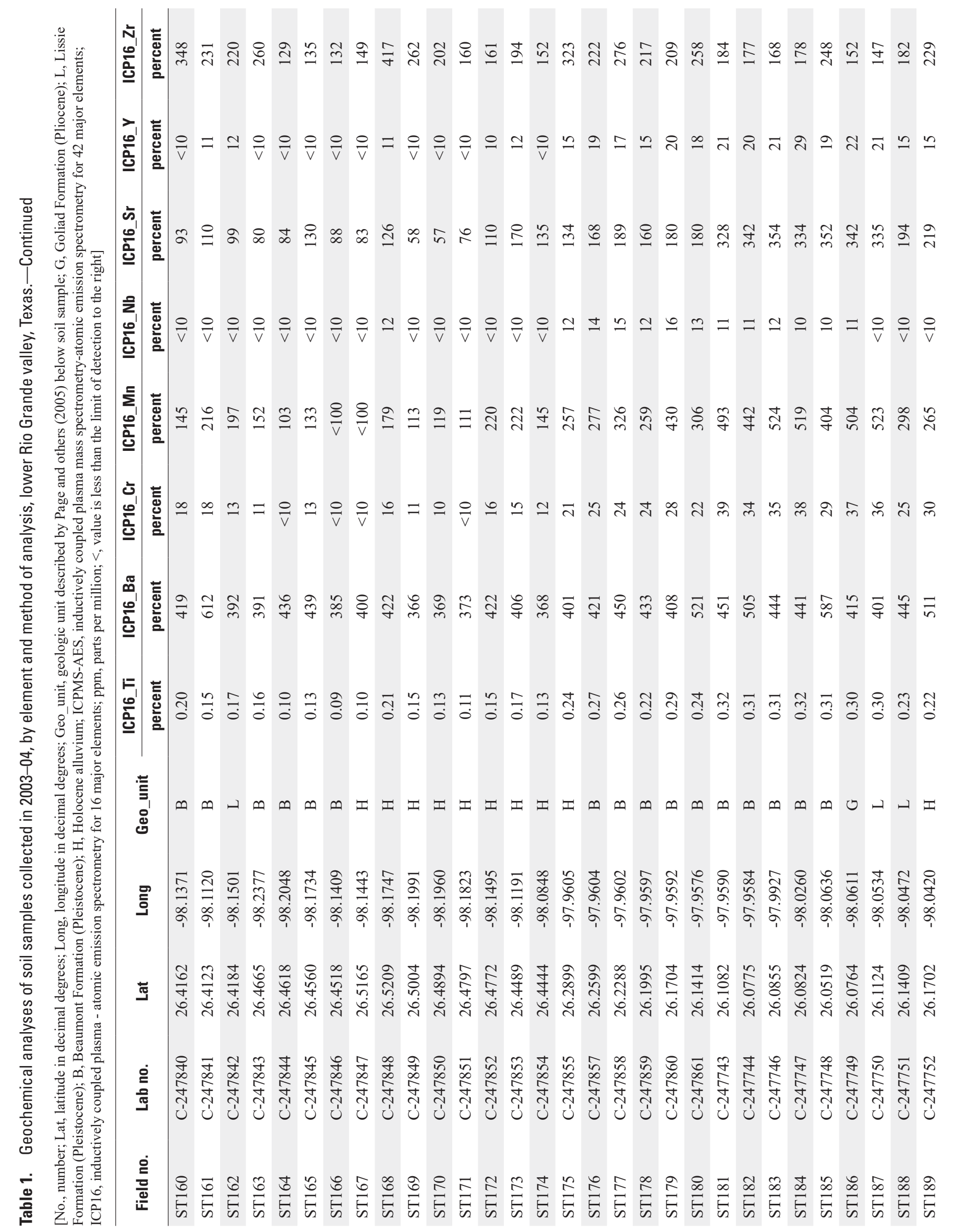




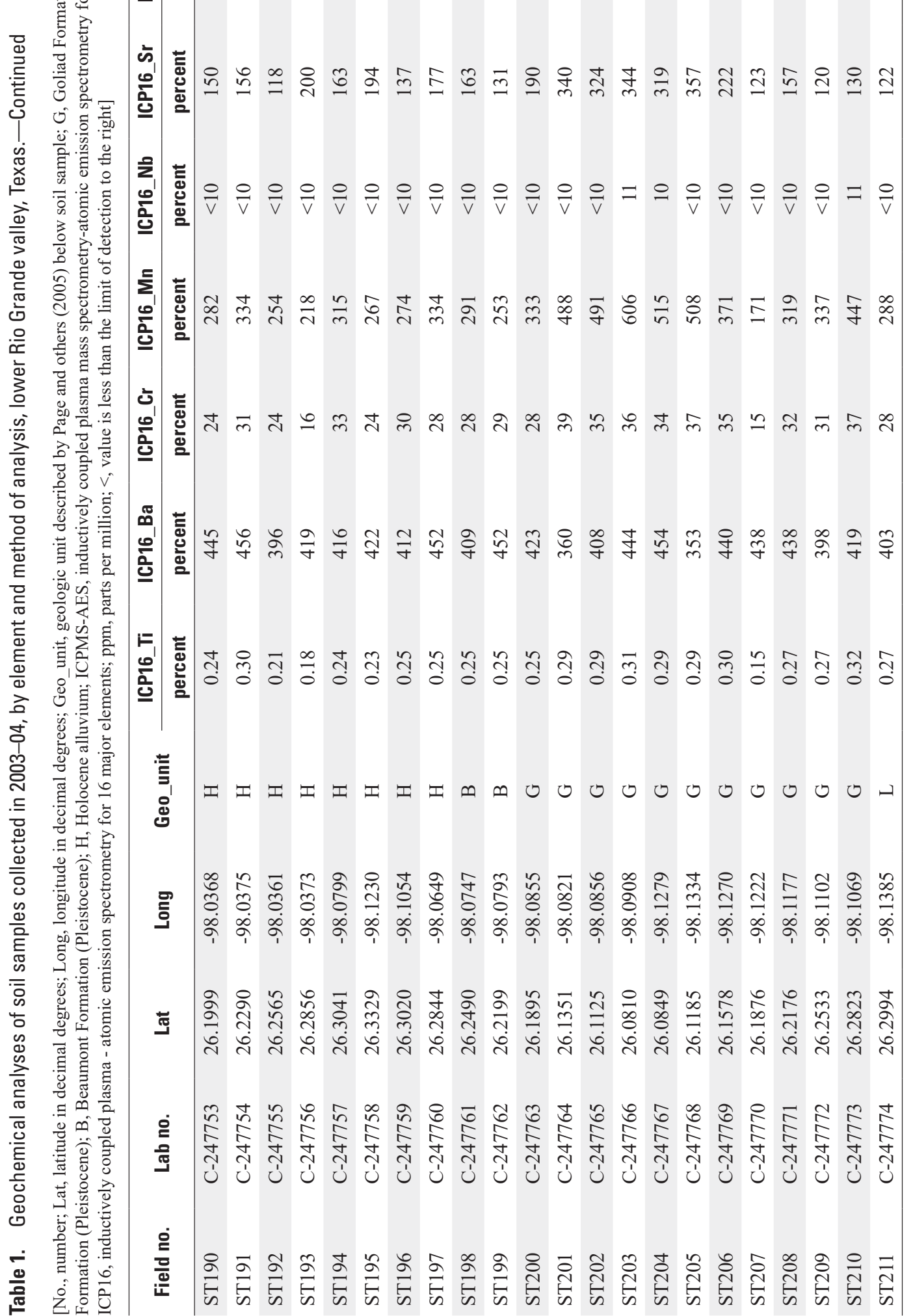

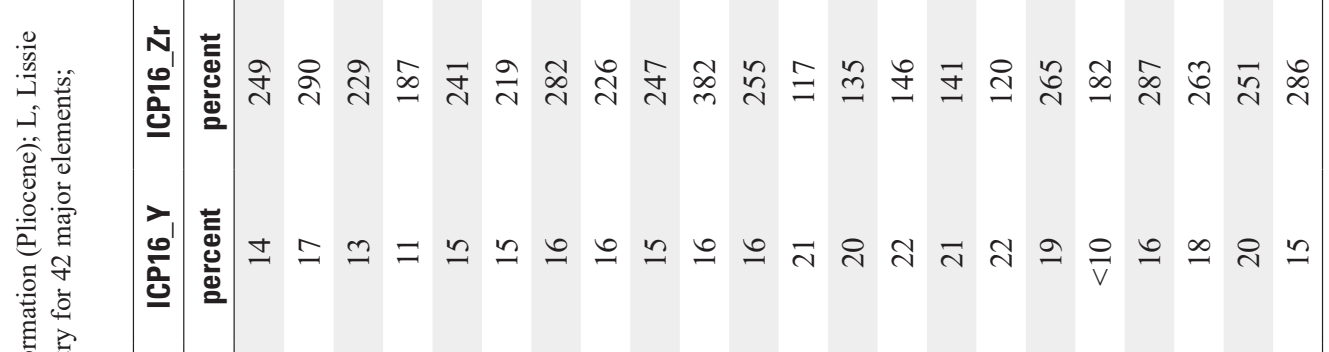




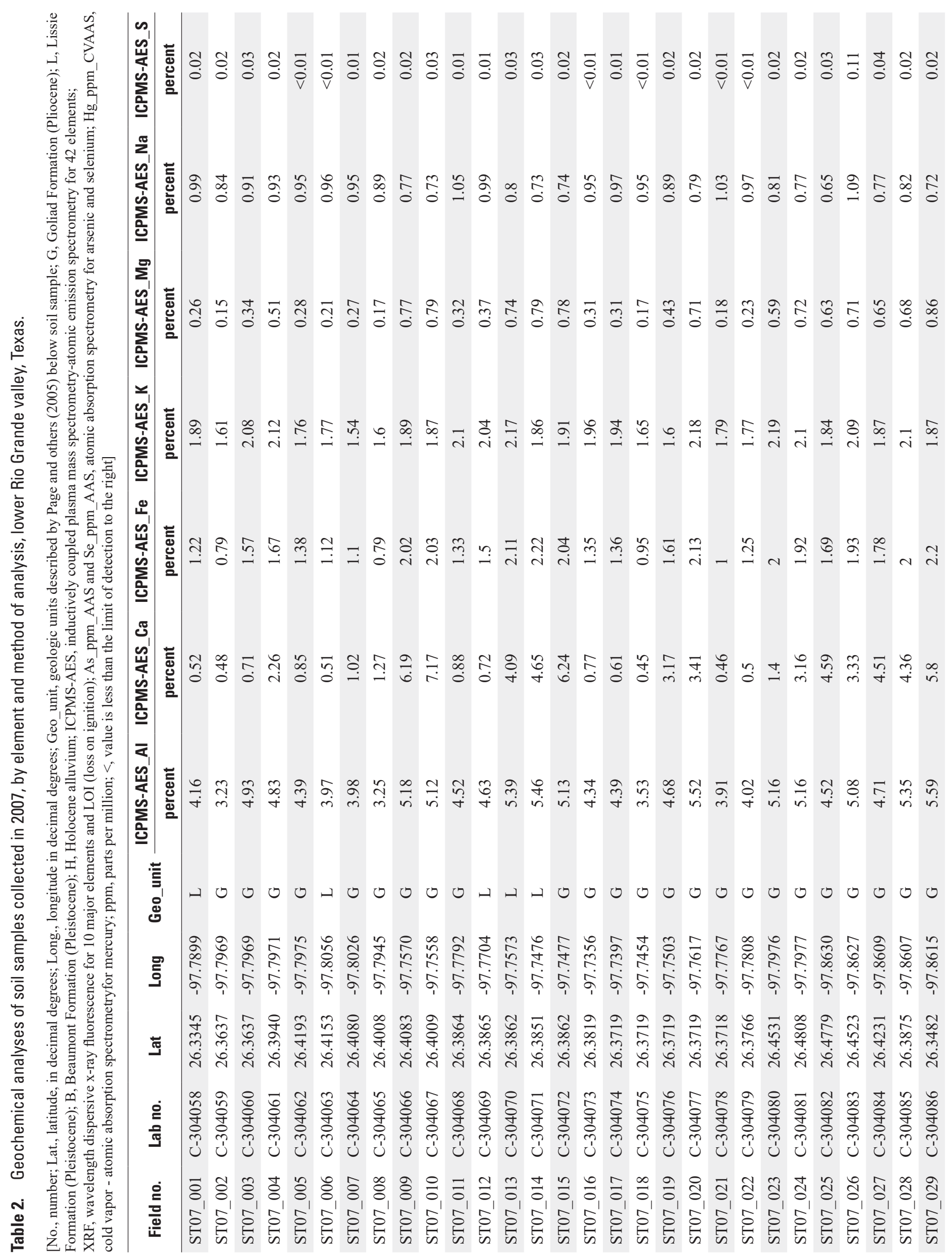




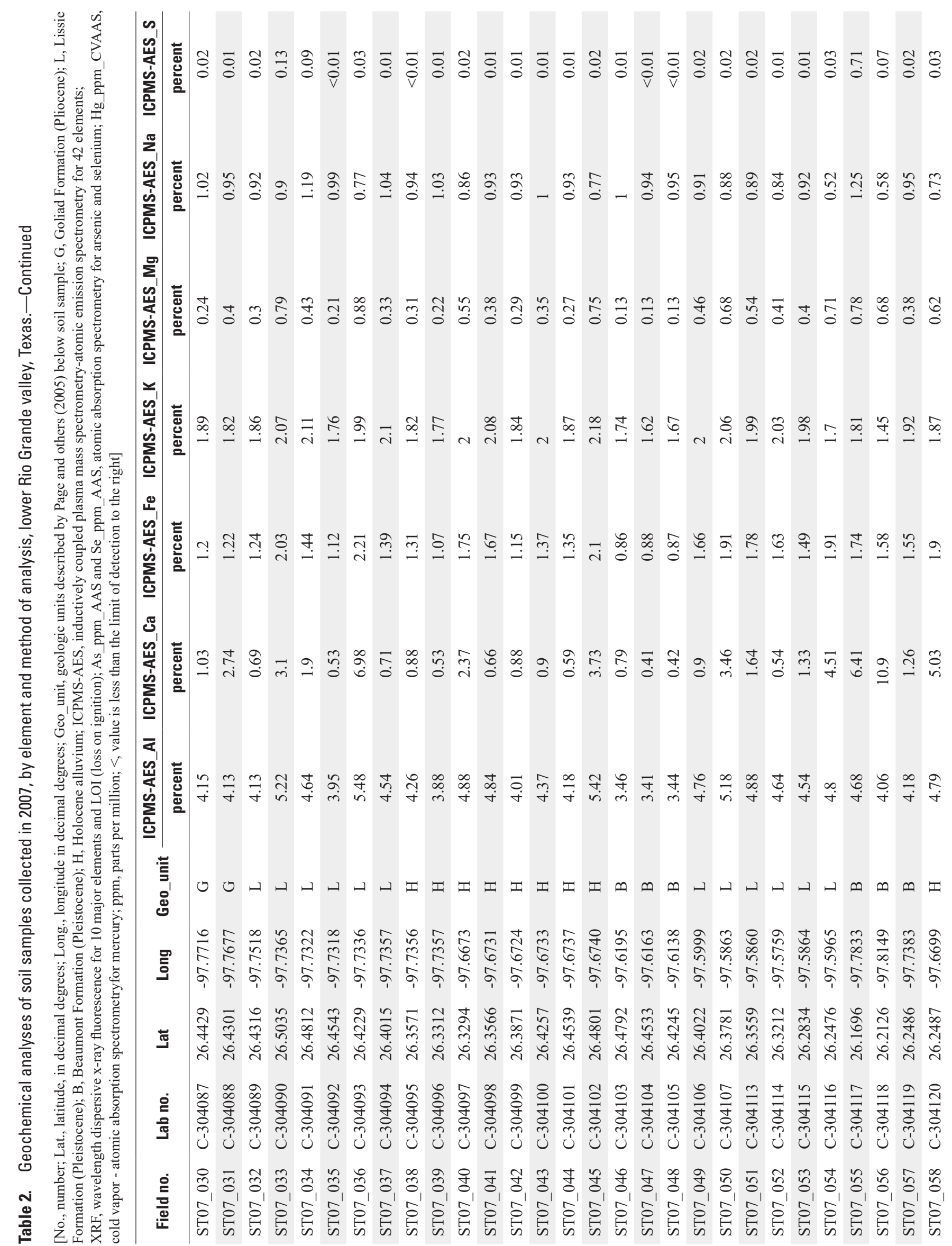




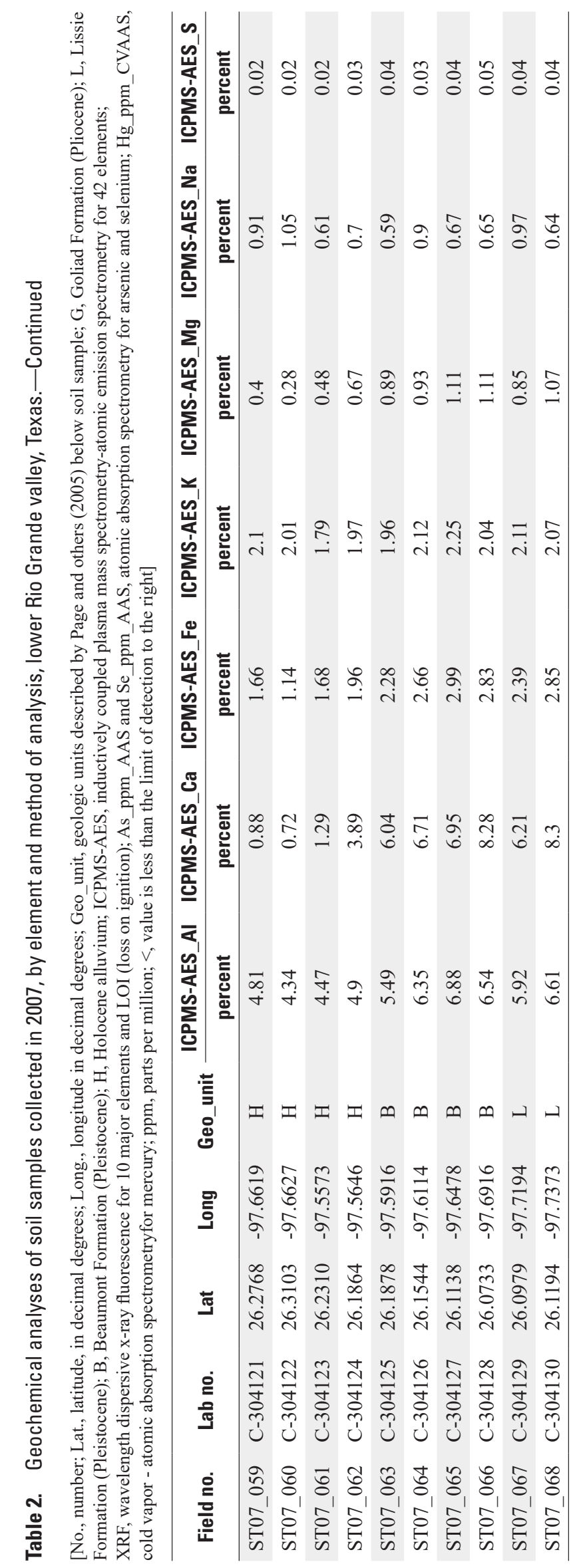



i

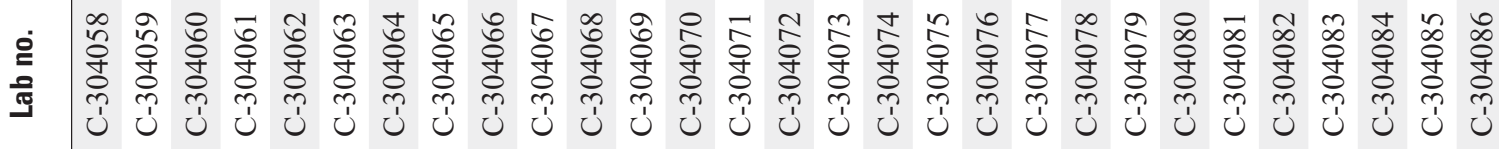

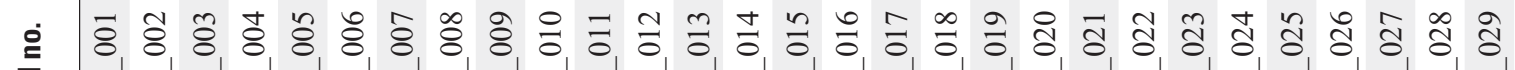

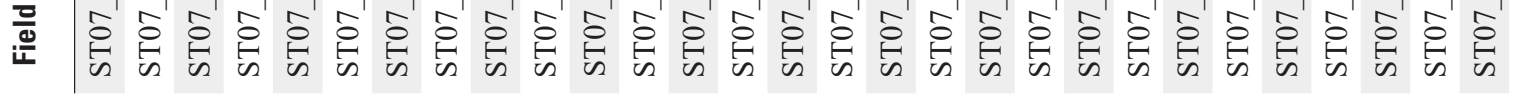




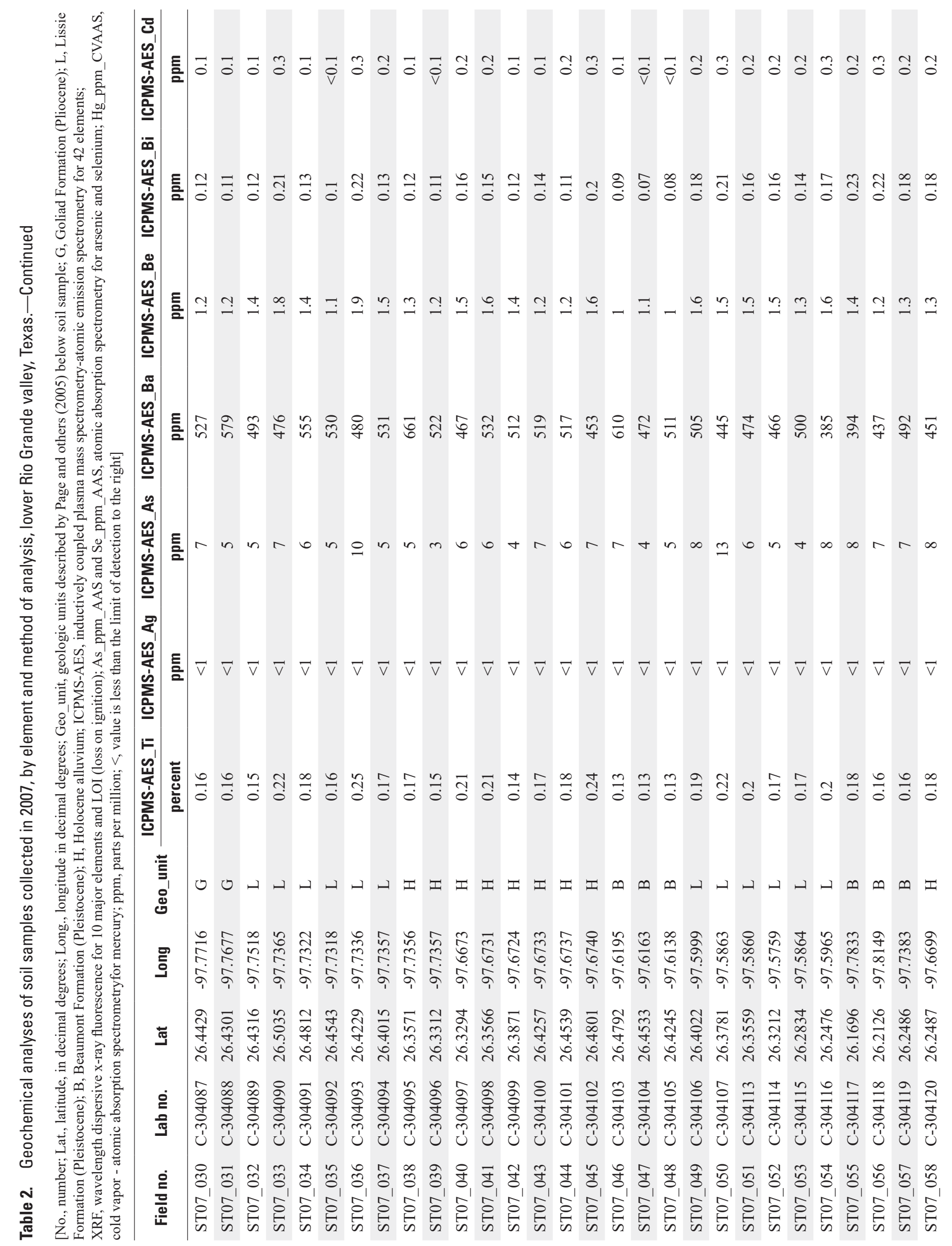




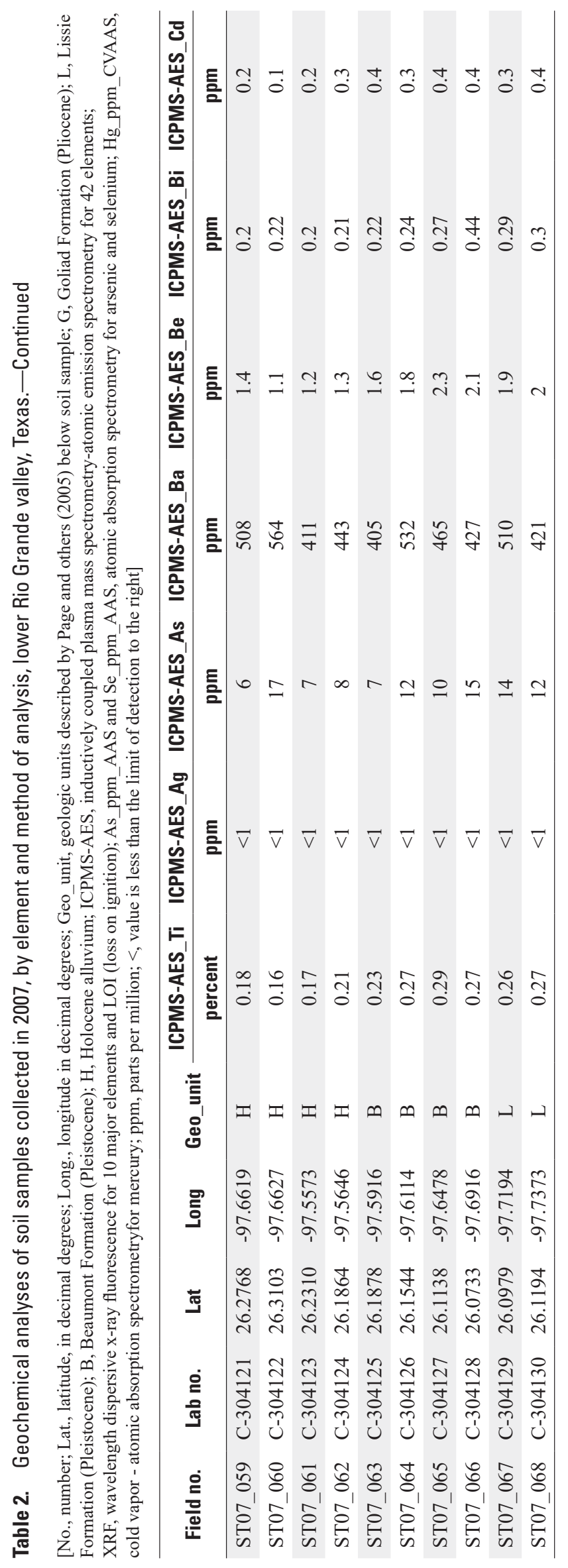




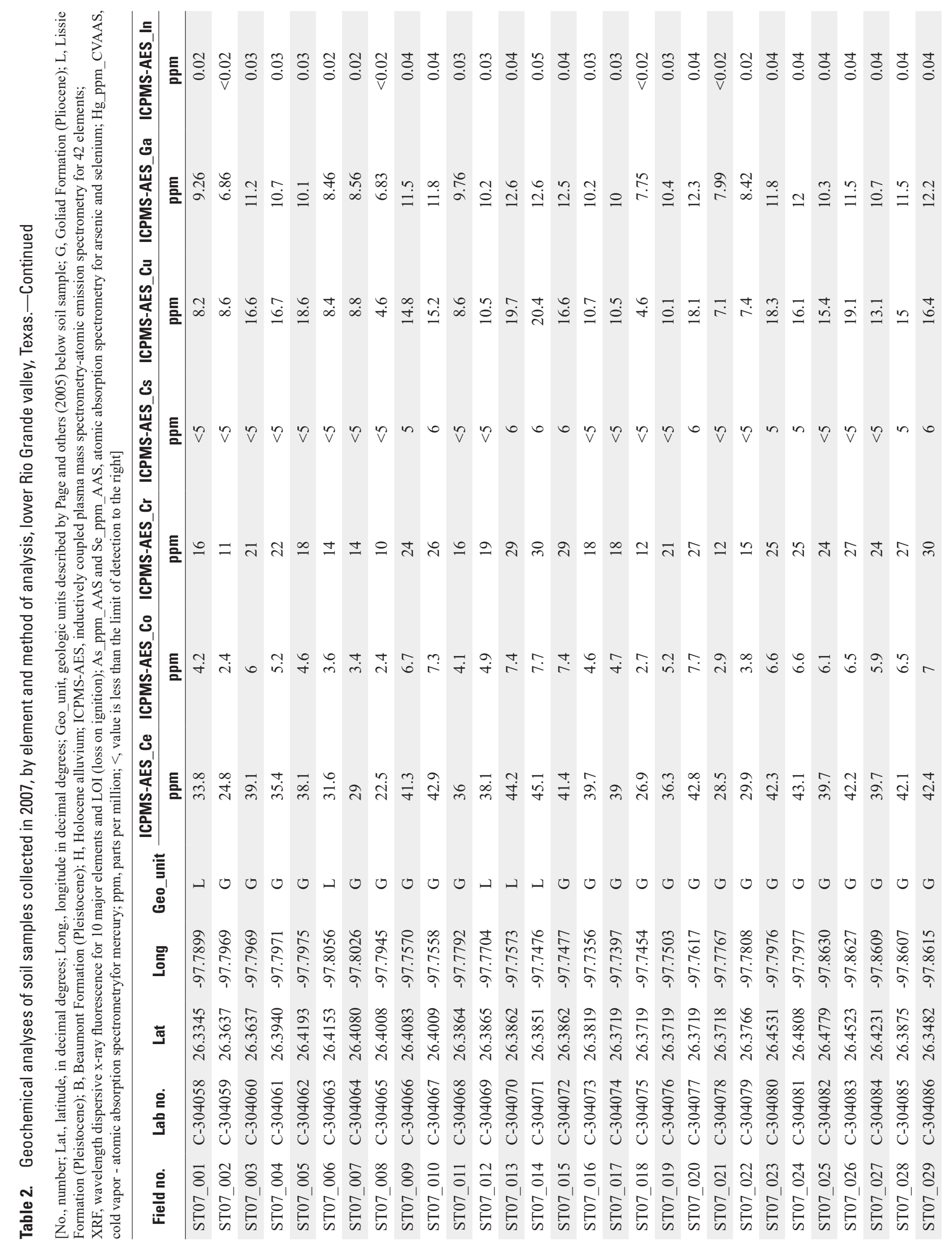




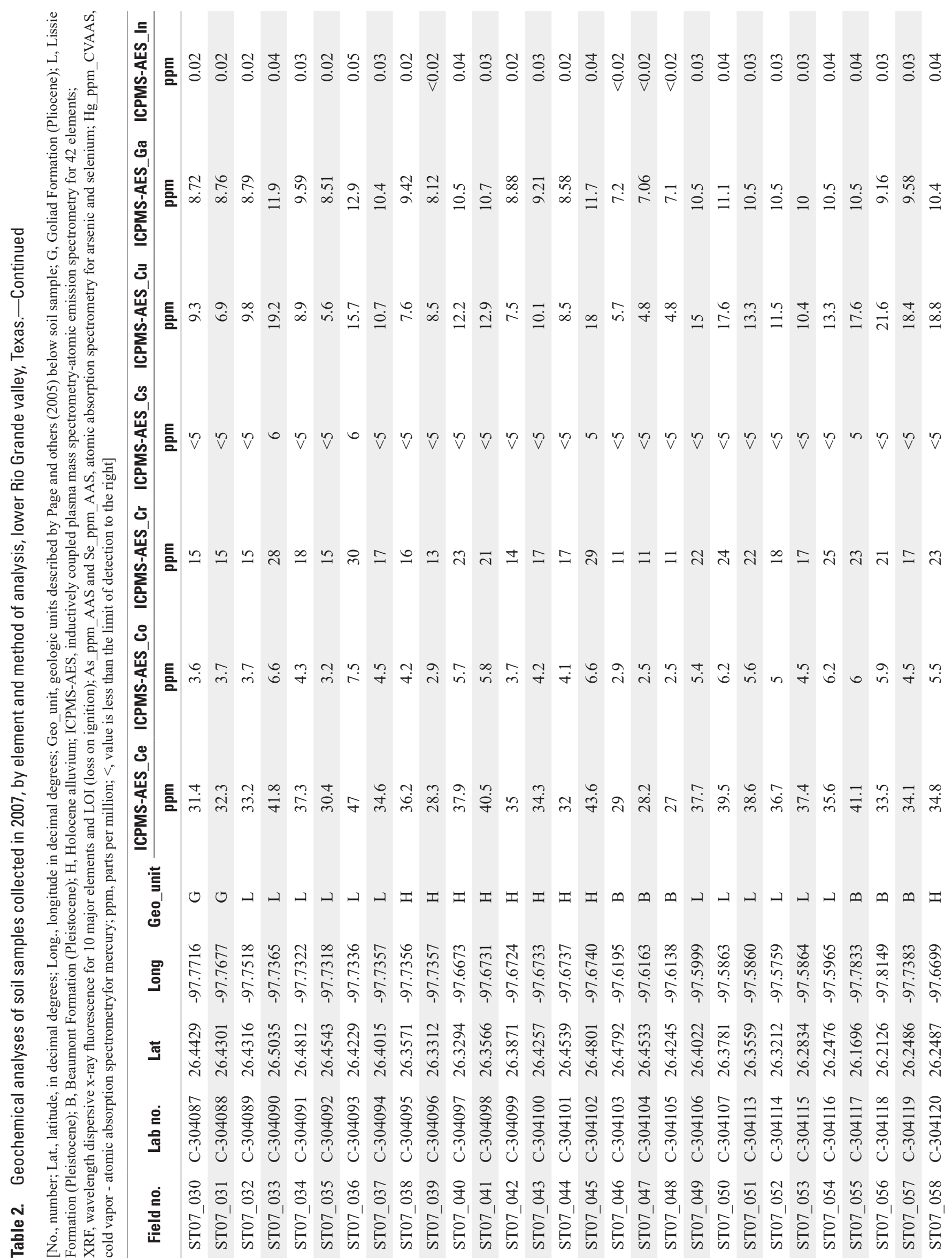




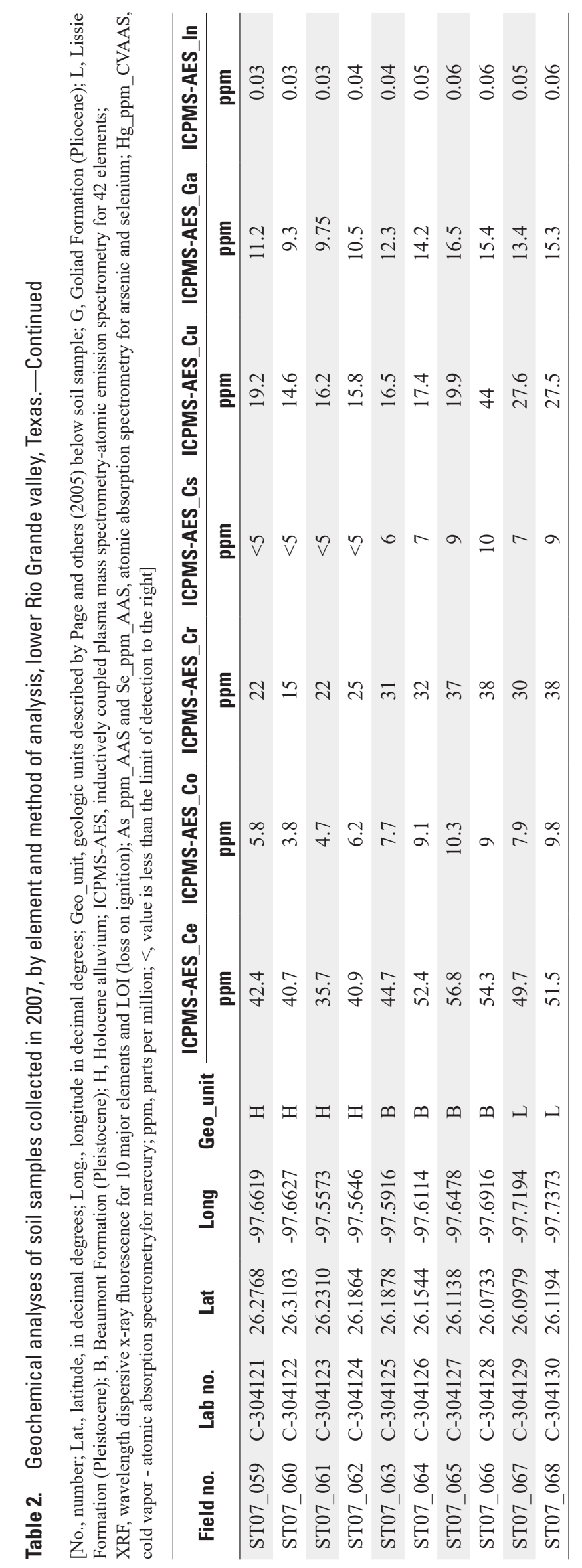




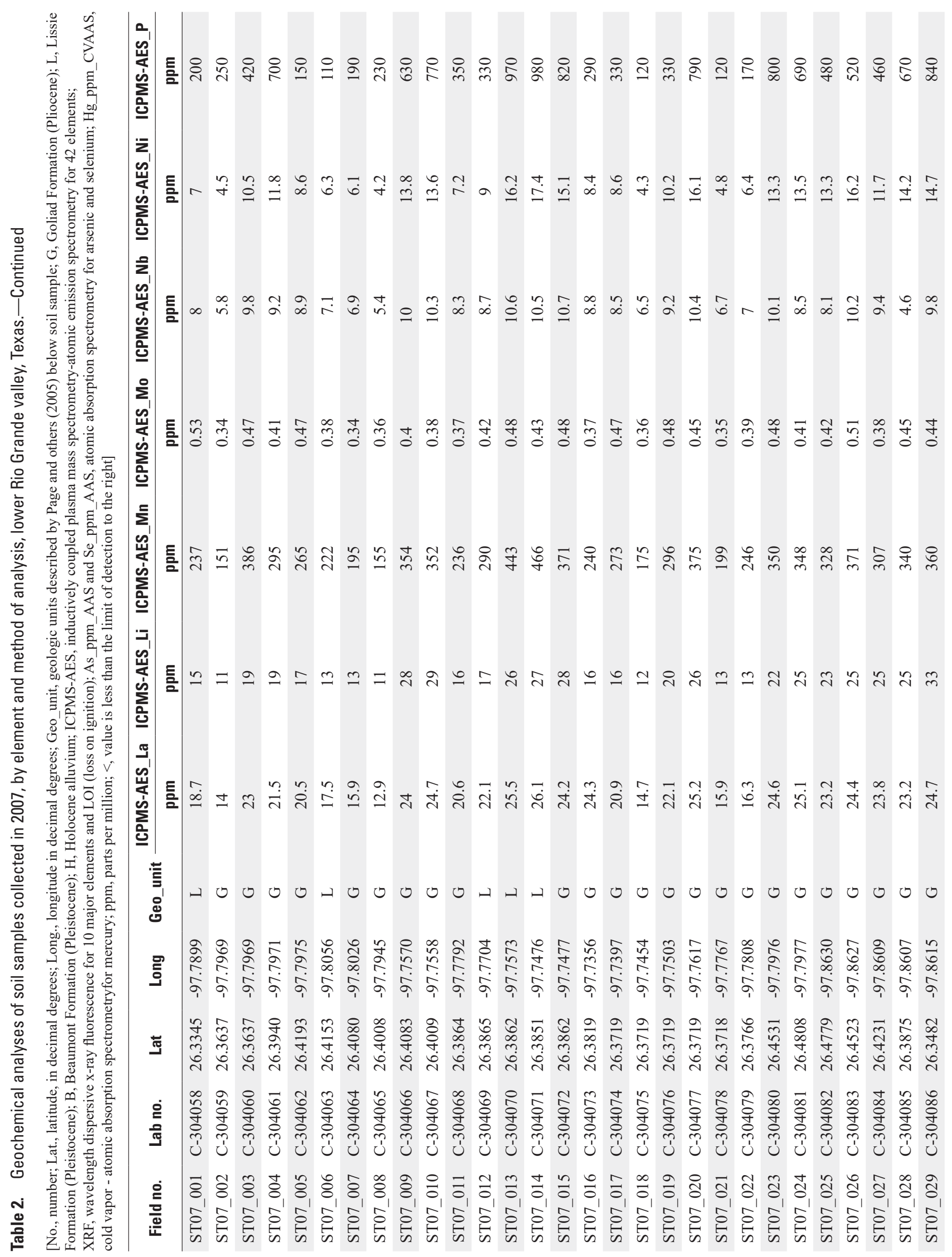




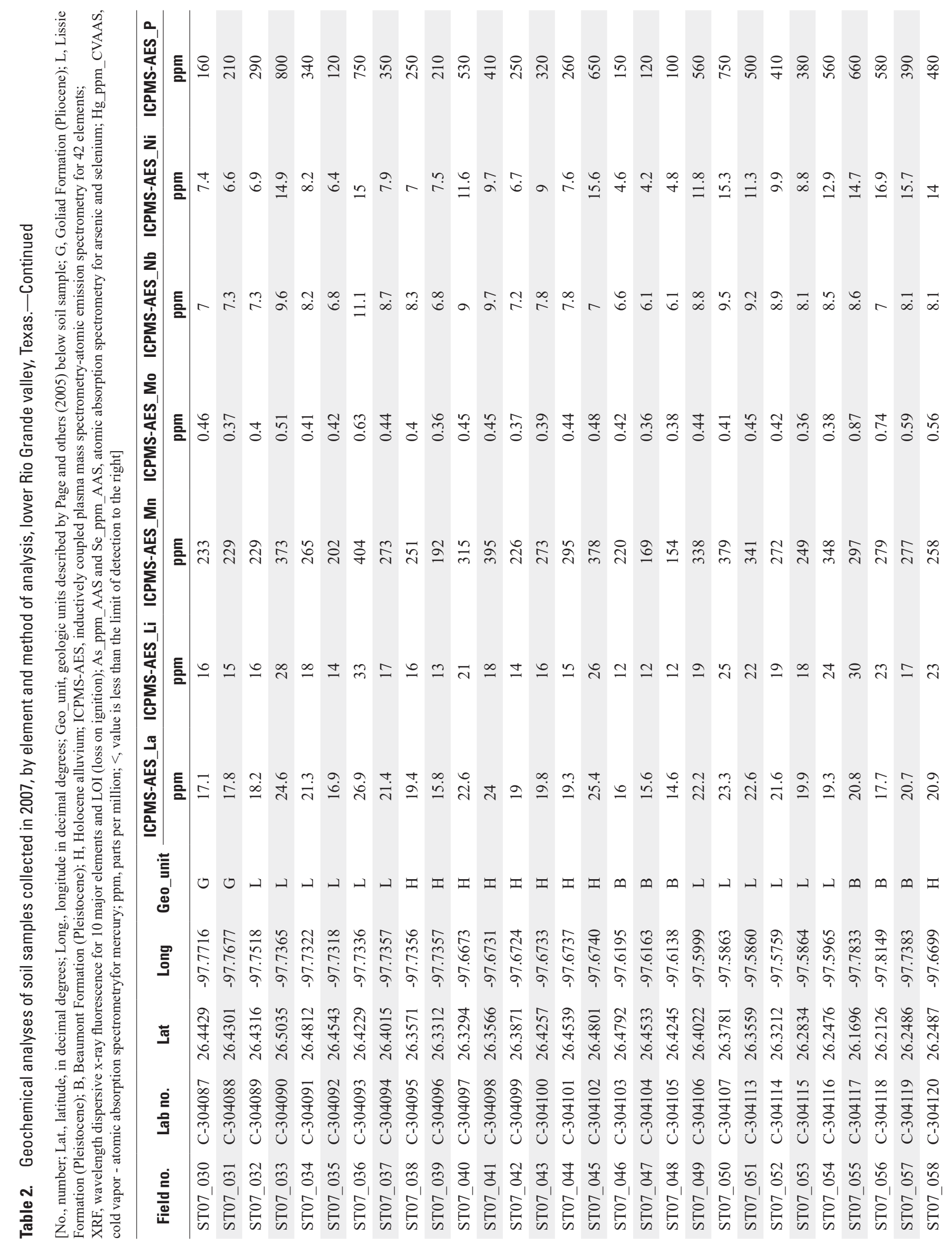




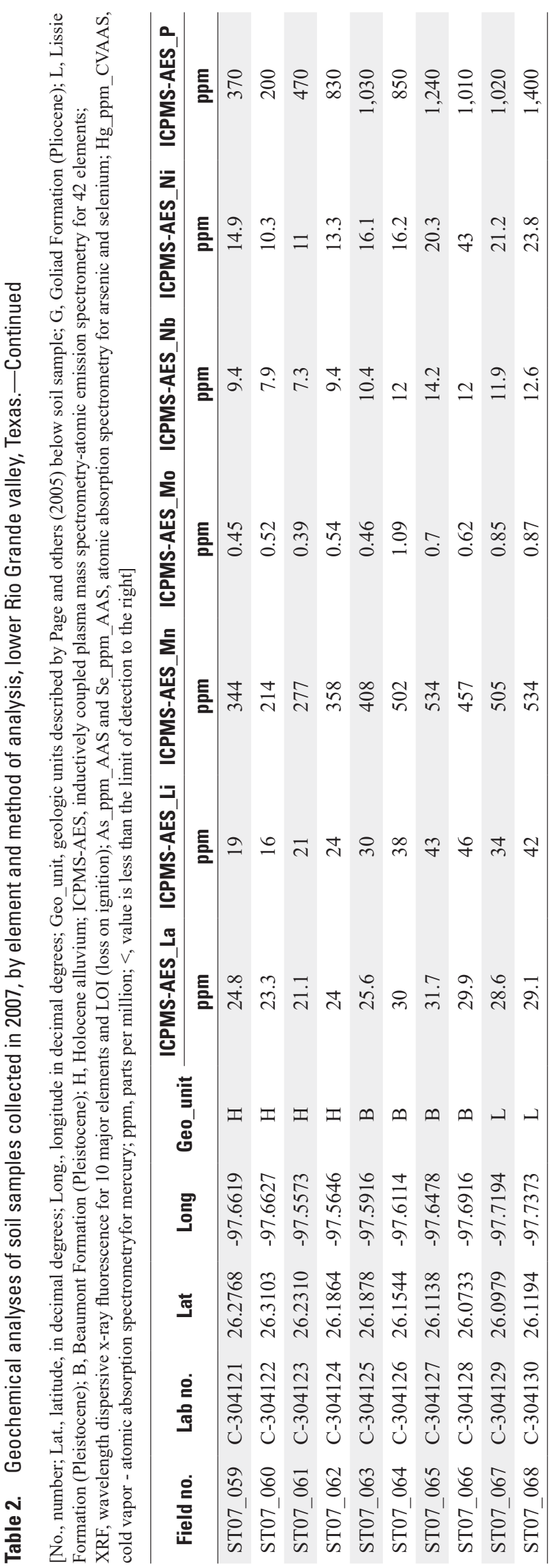




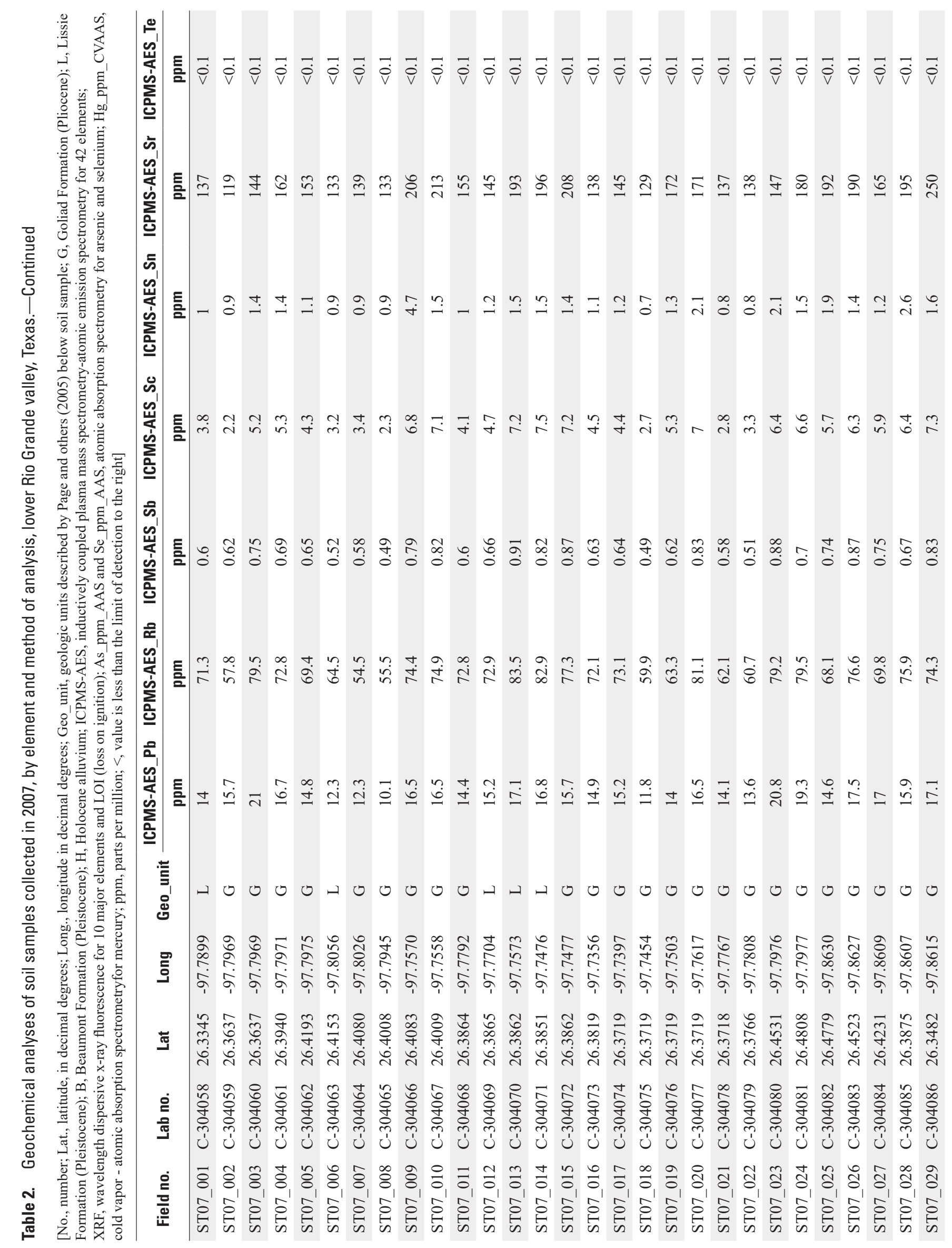


Table 2

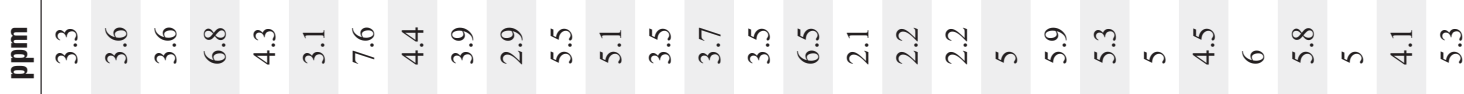

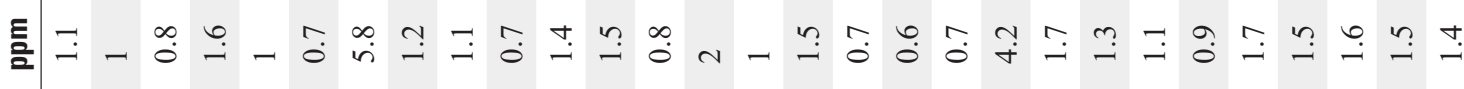

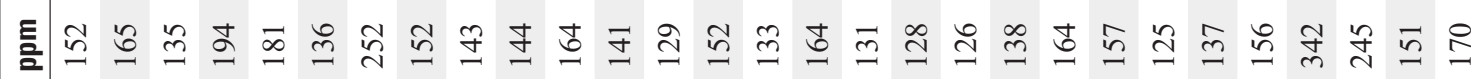

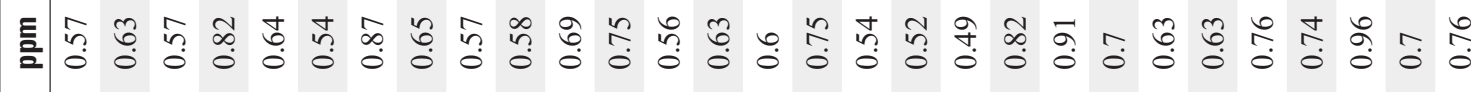

言

崖 घ5

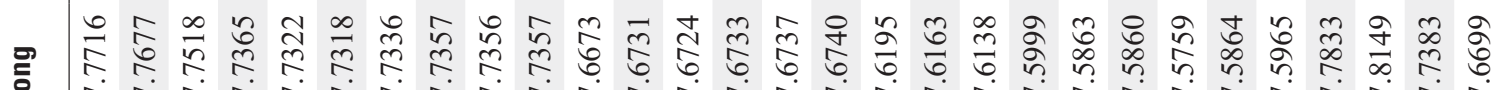

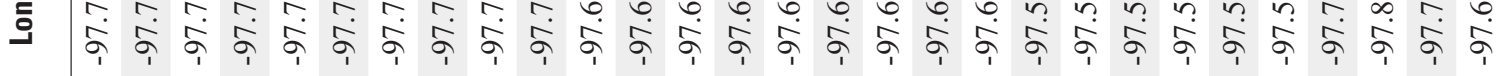

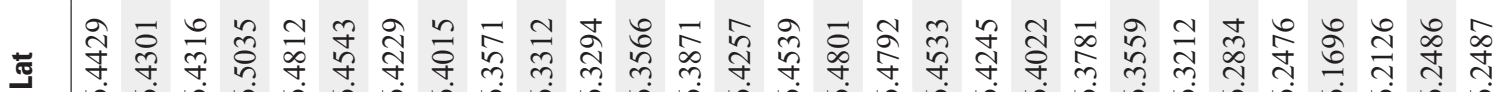

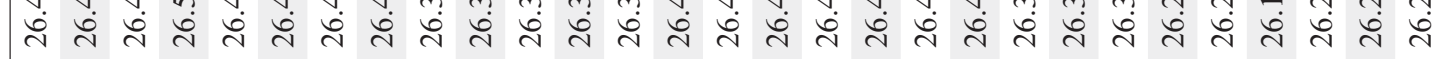

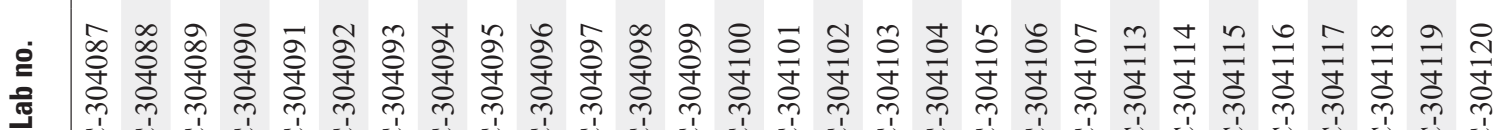

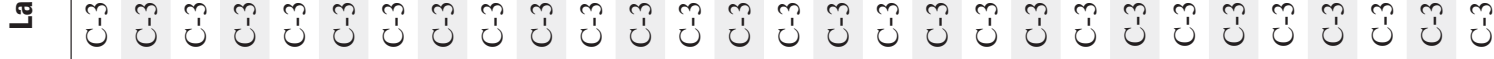

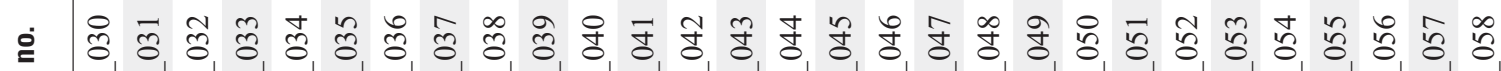

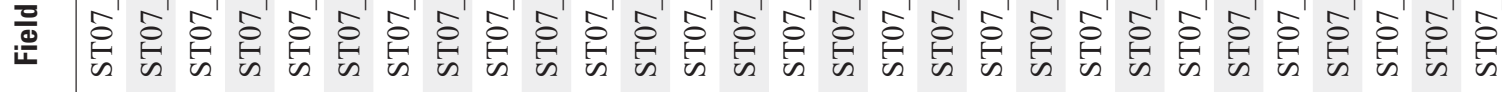




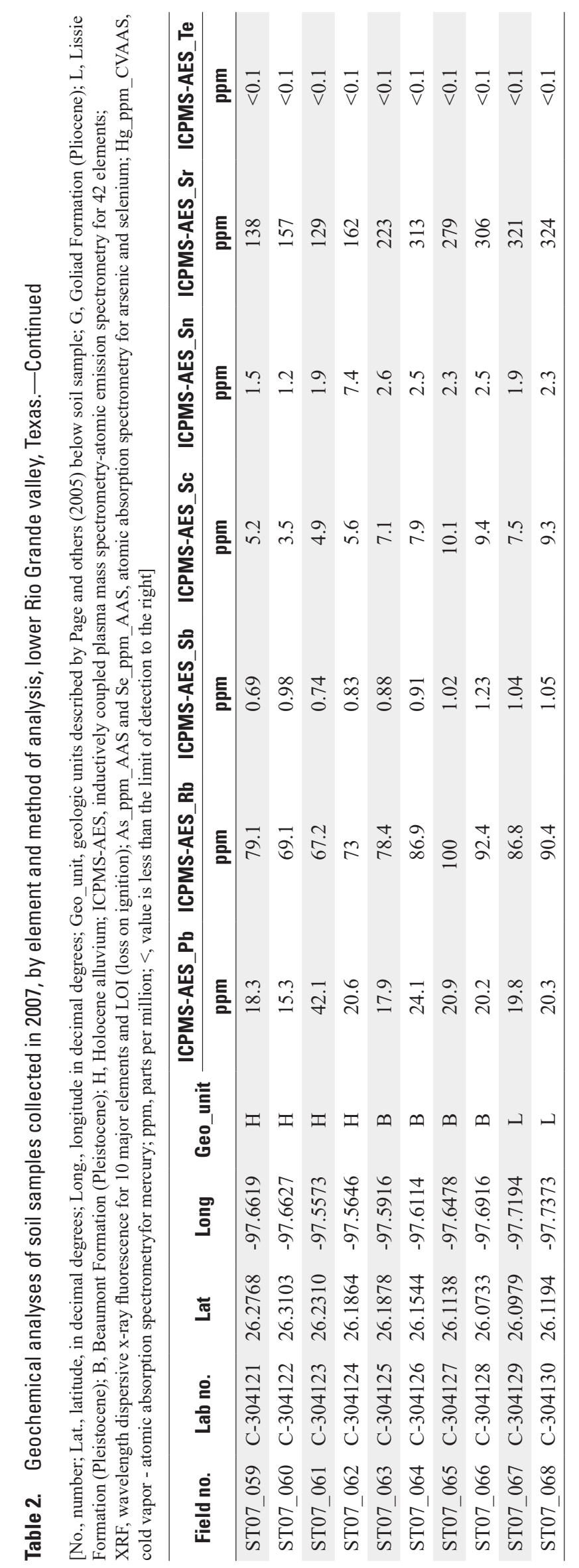




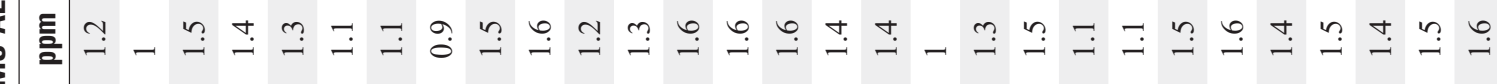

言 든

F

蓆

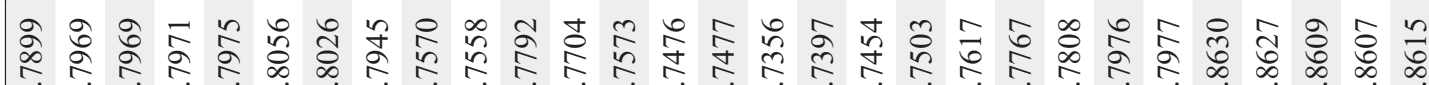

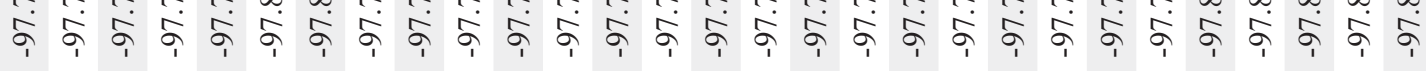

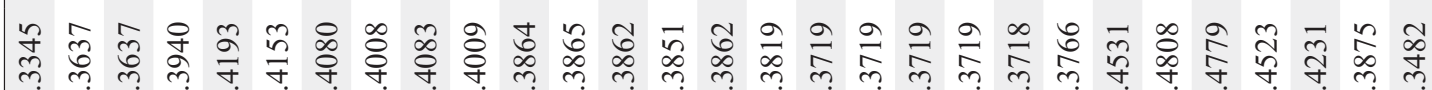

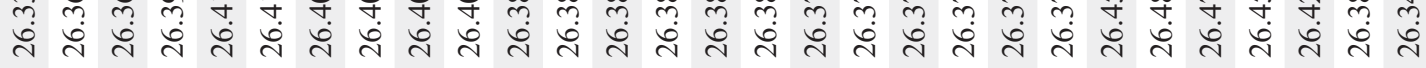

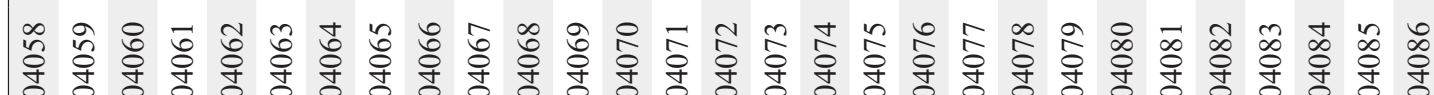

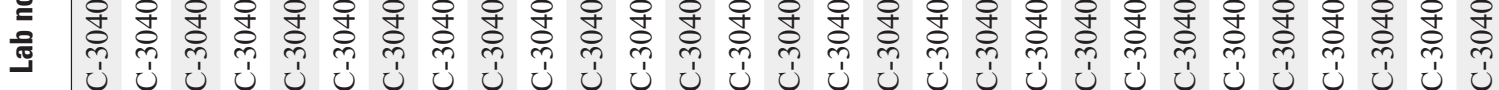

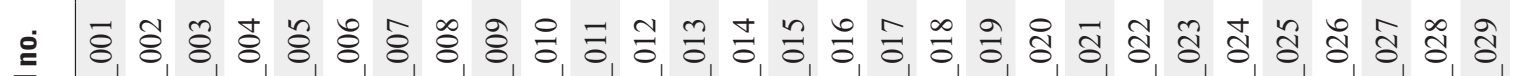

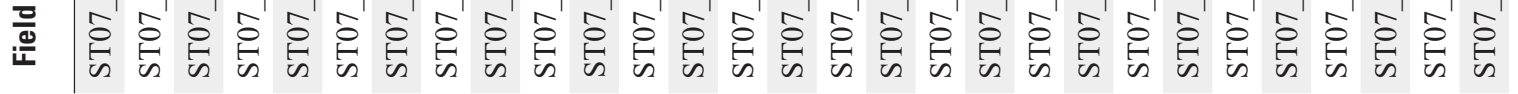




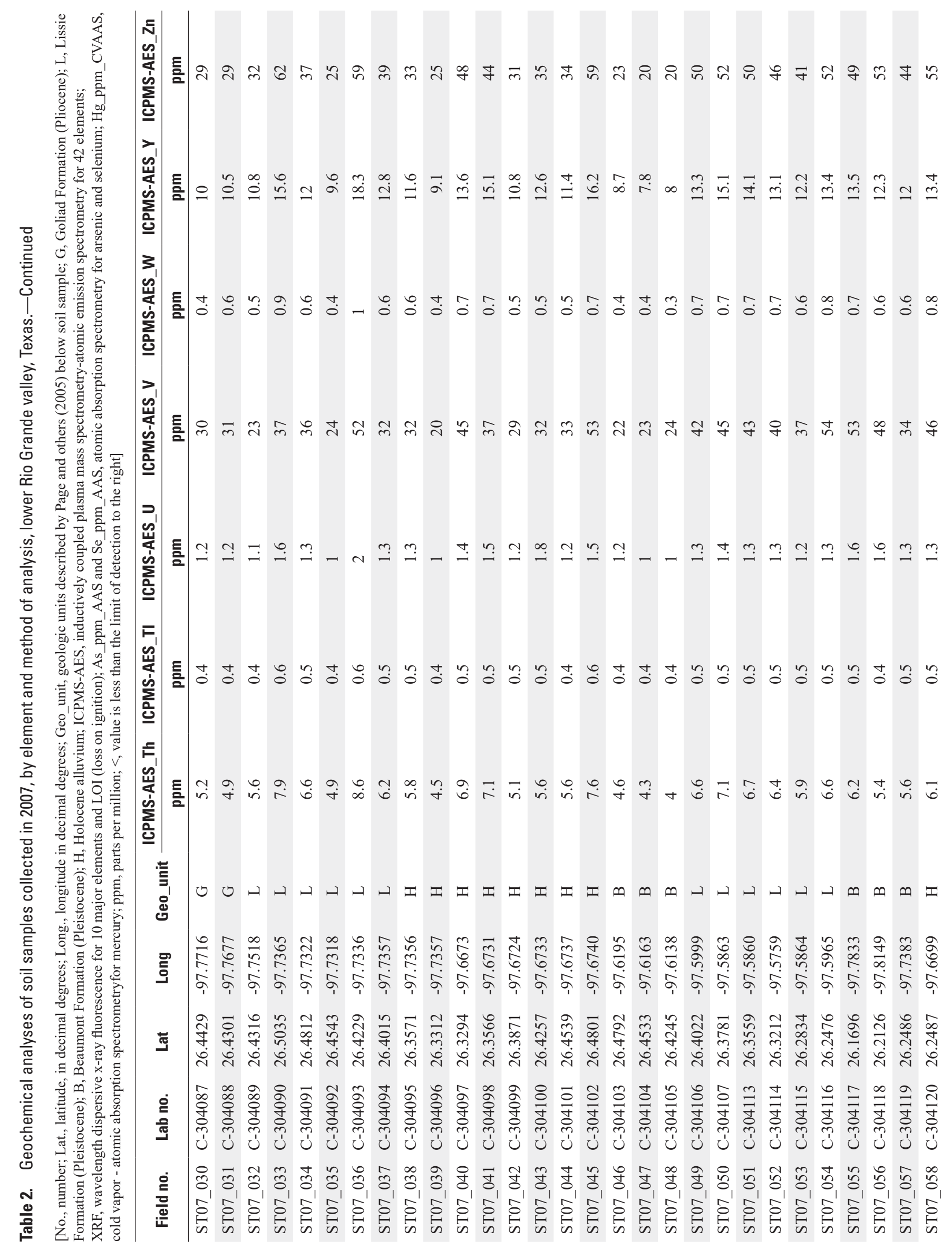




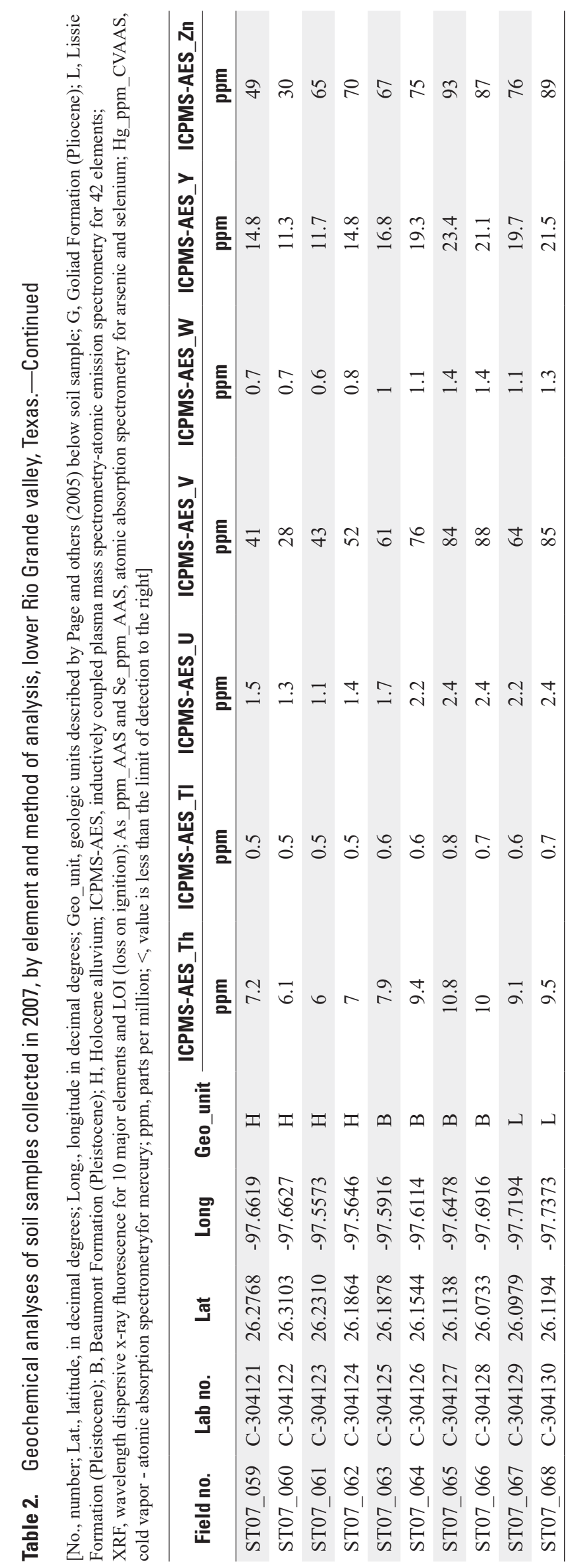




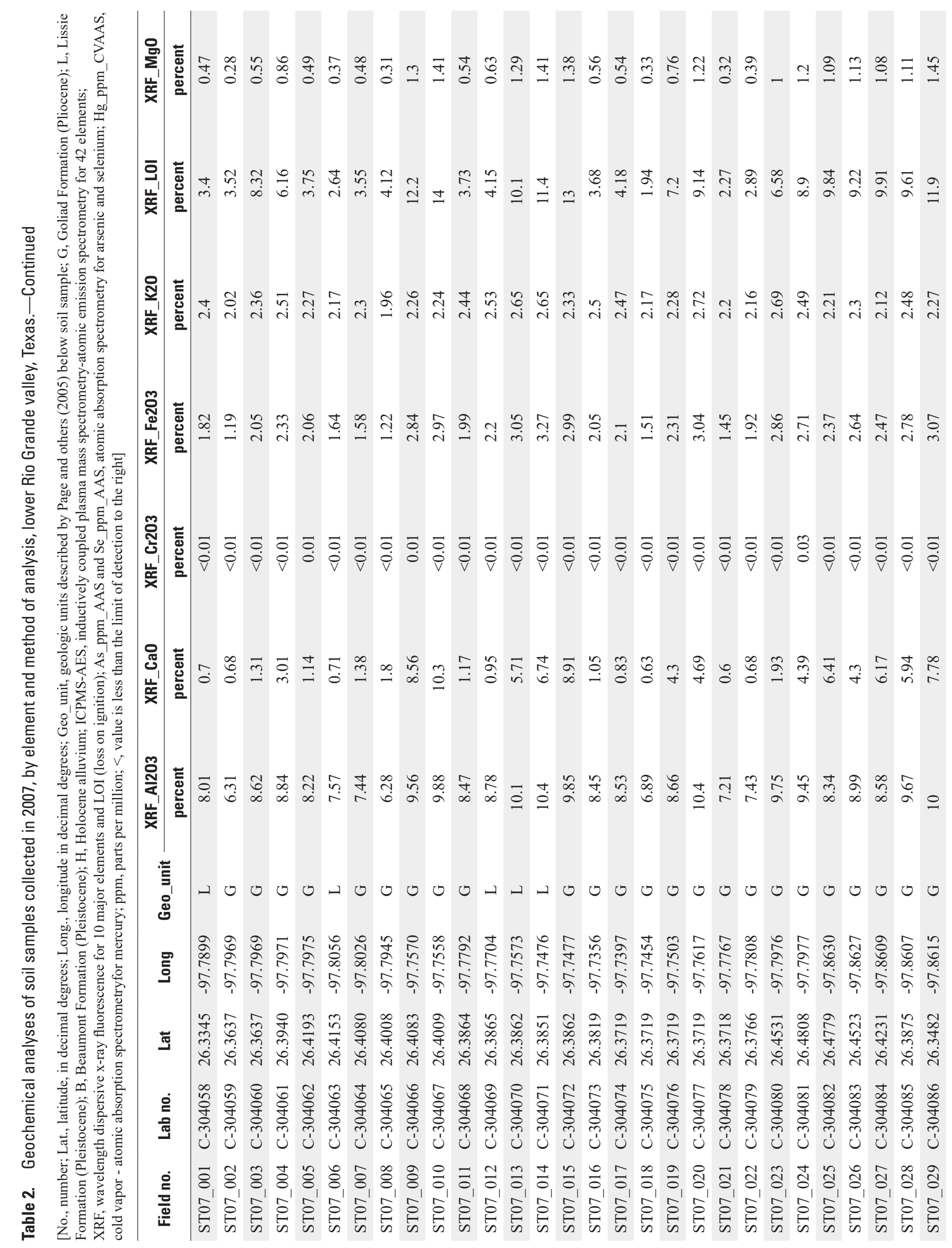




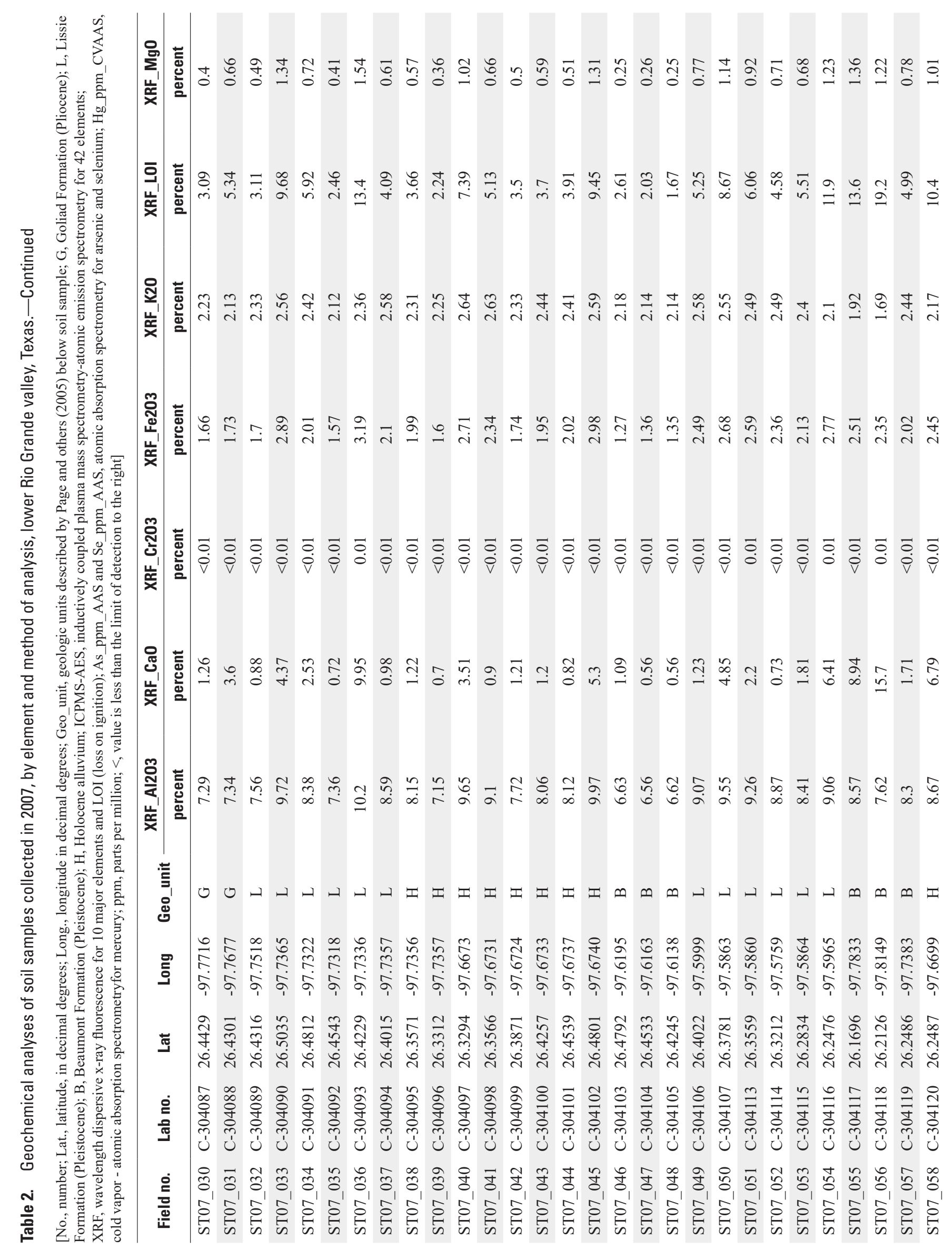




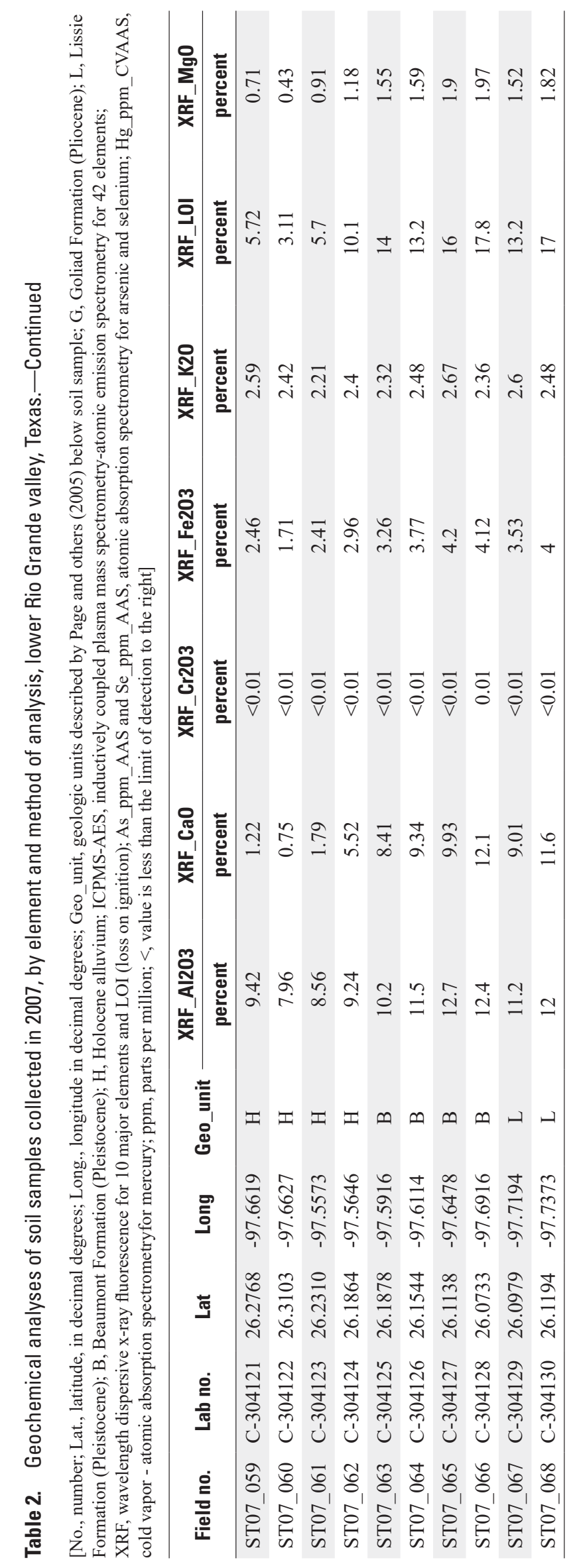




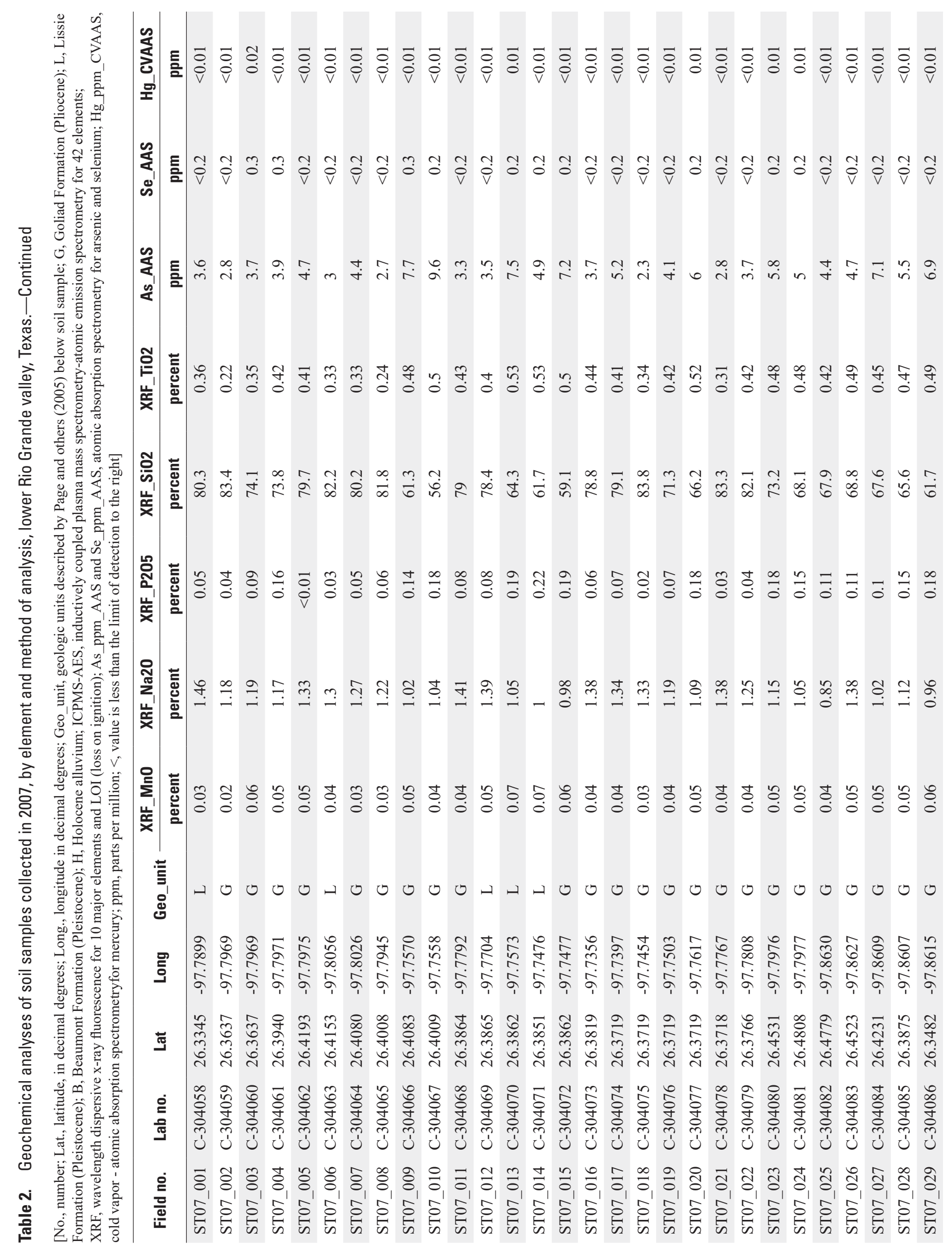




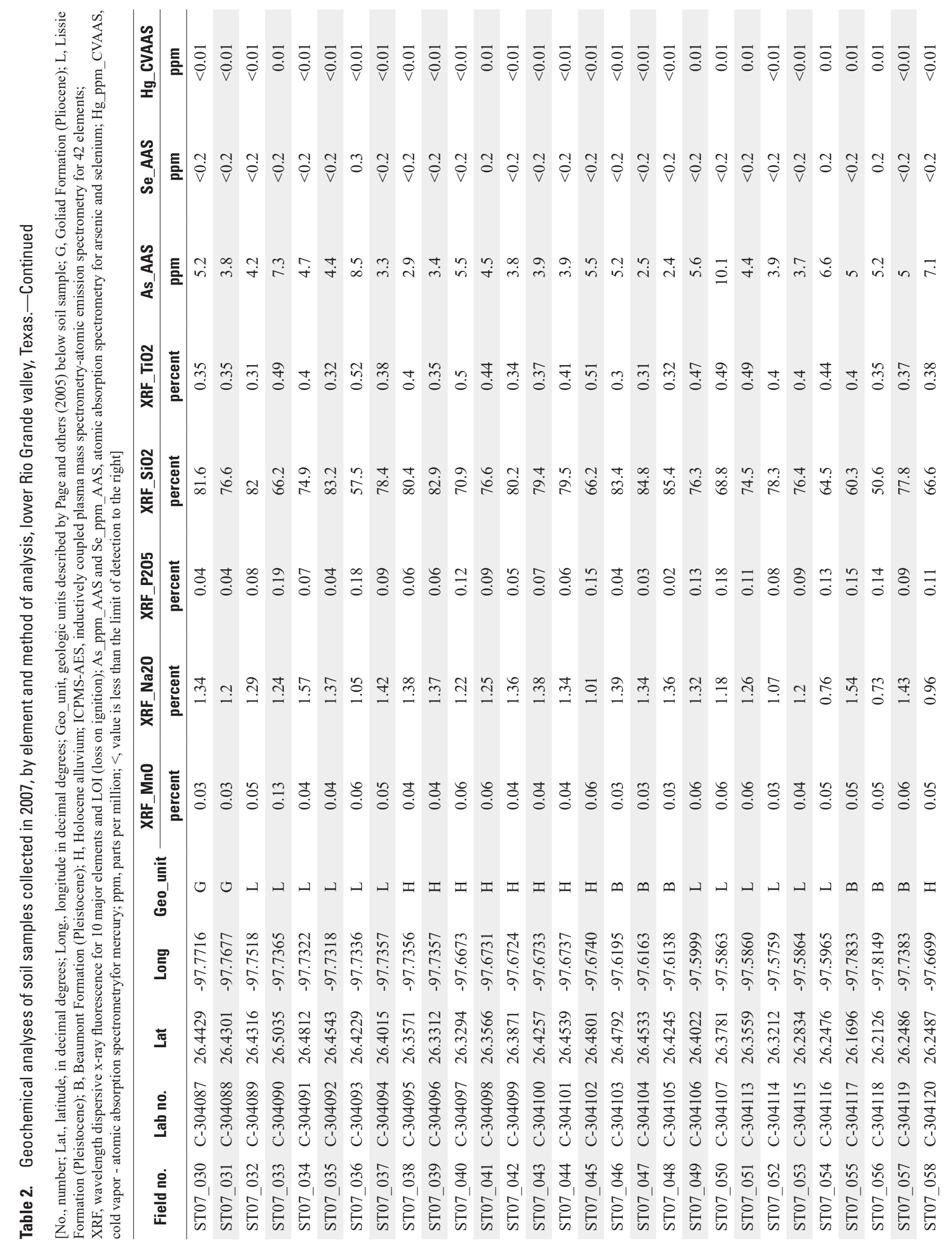




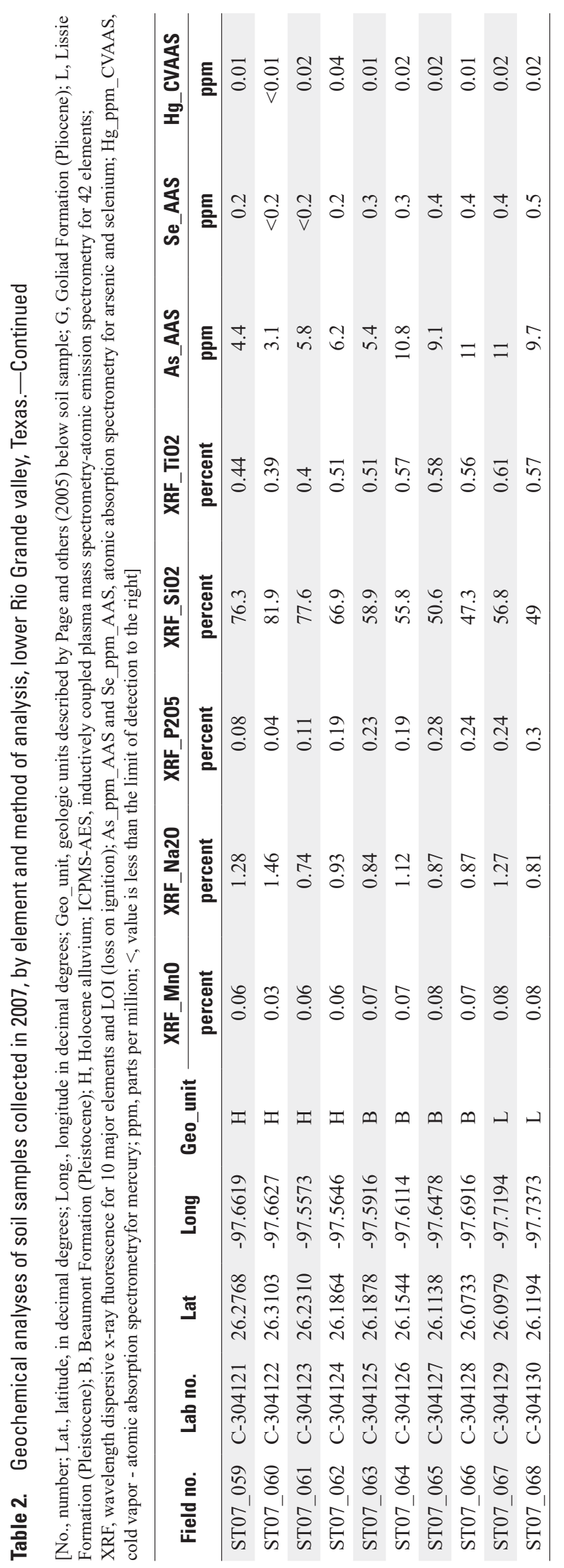




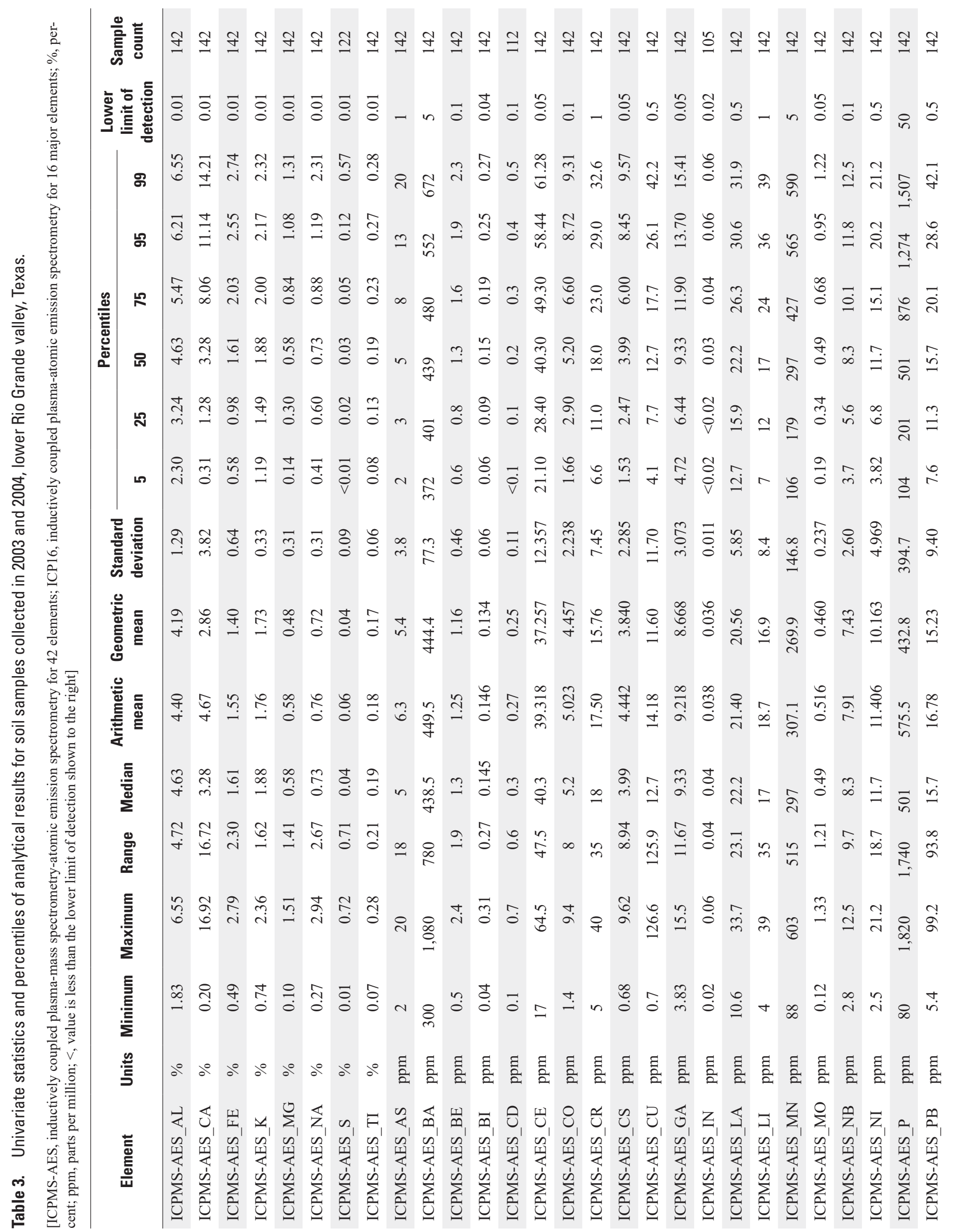




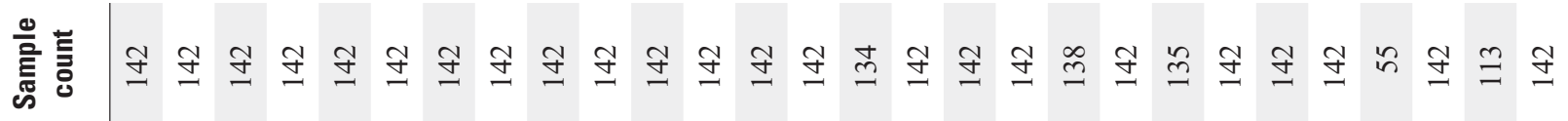

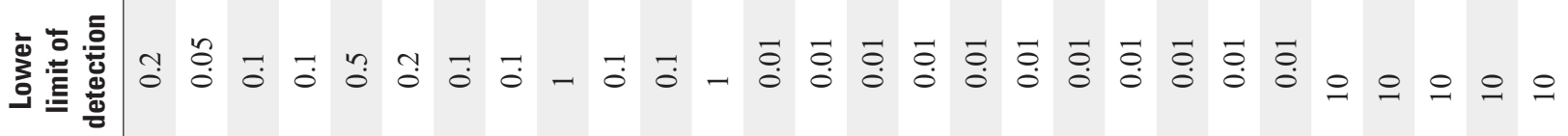
g चु

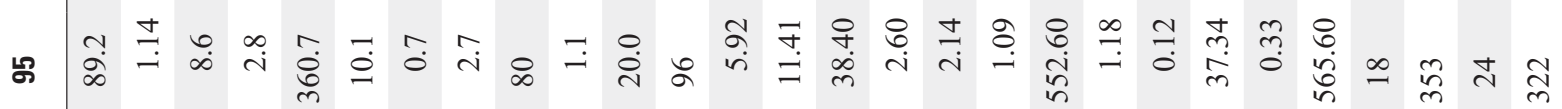

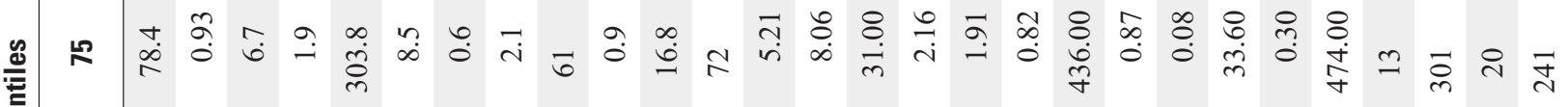

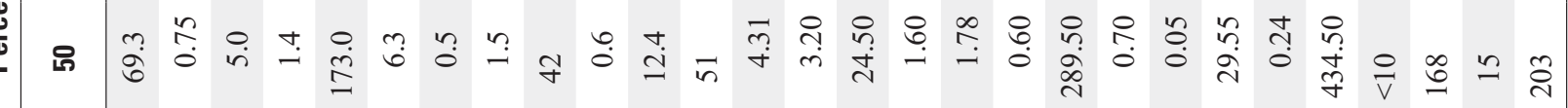

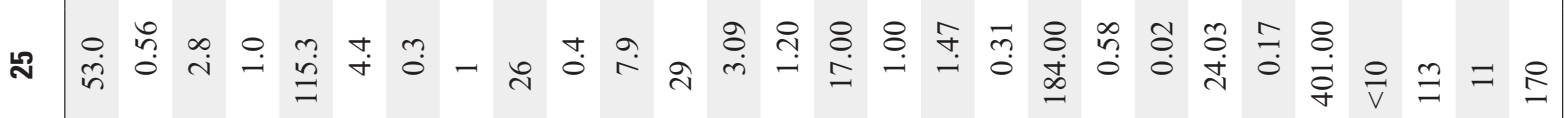

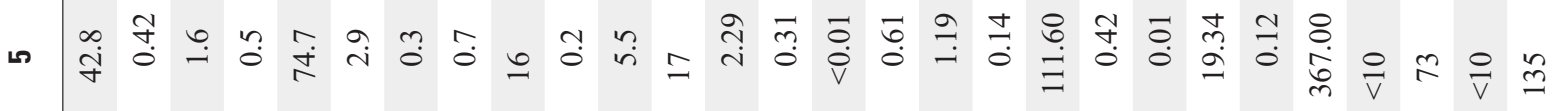

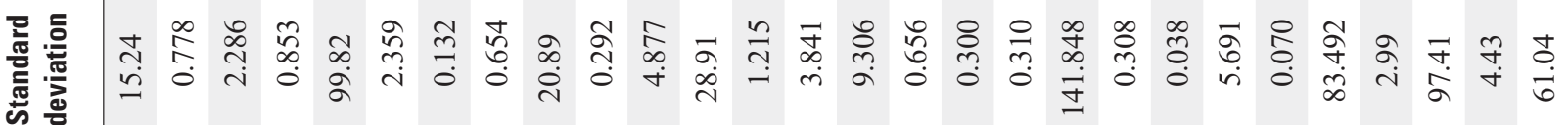
产 过节 过

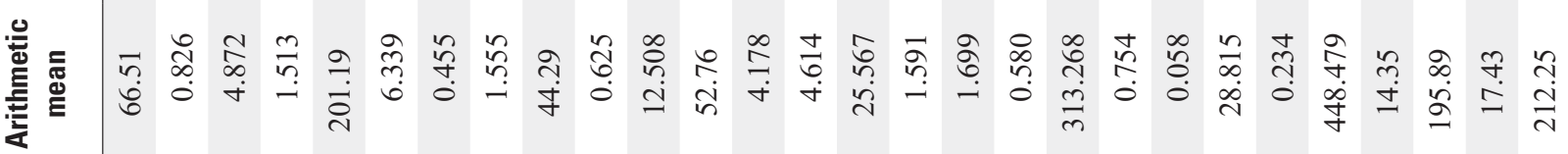
焉 焉

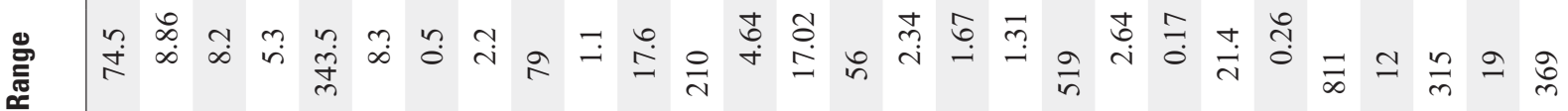
衰

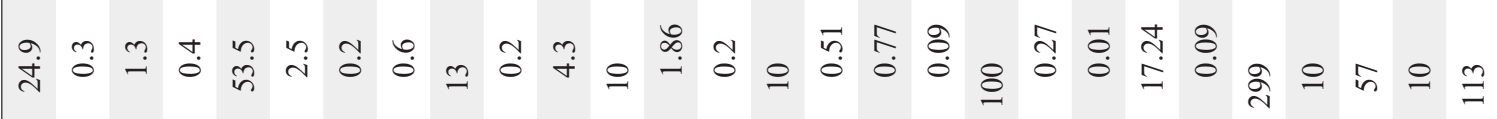

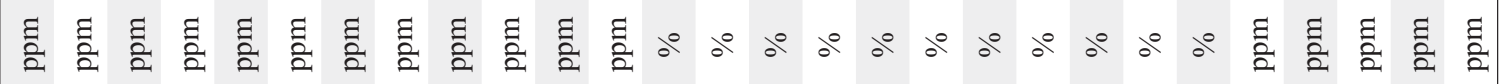

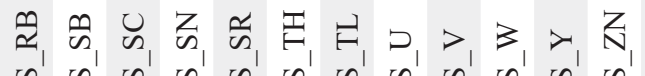

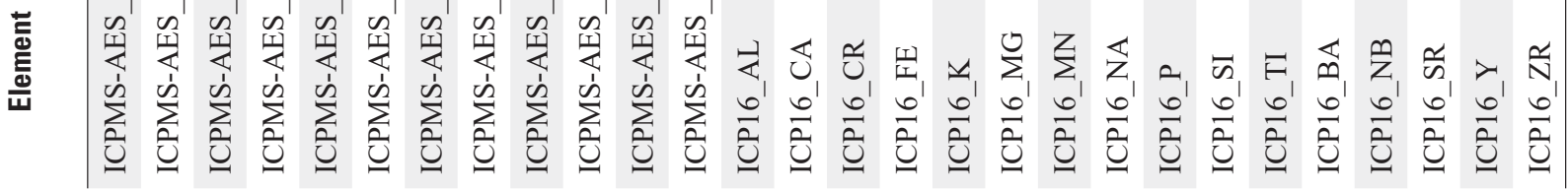




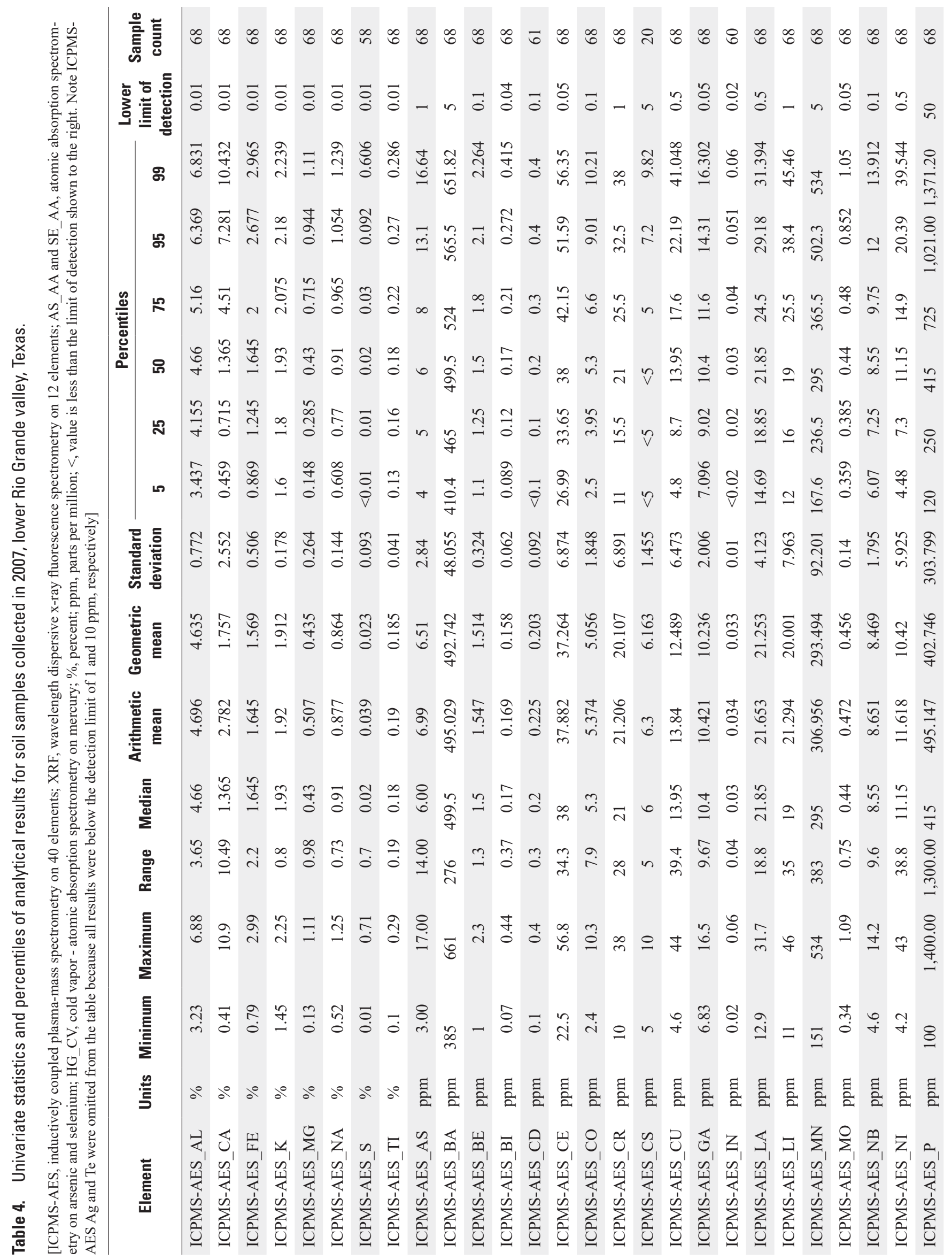




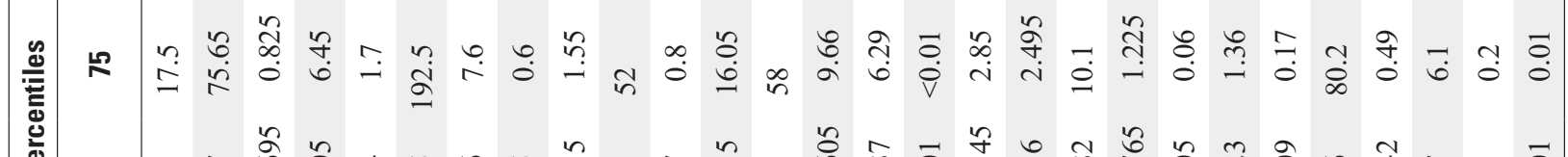

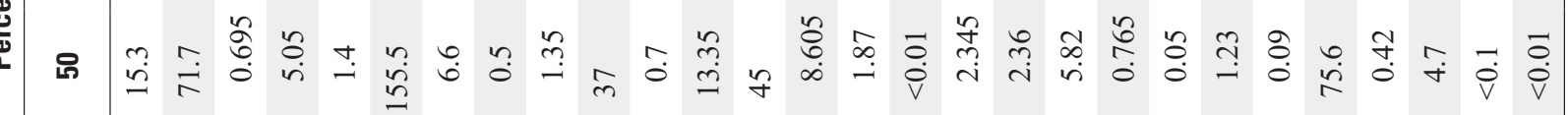

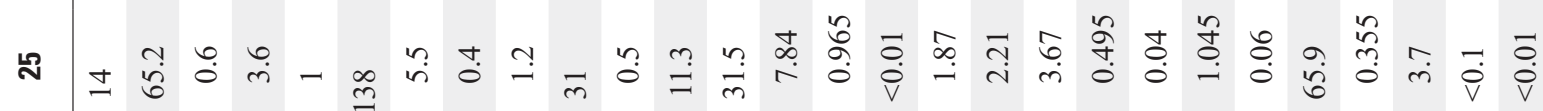

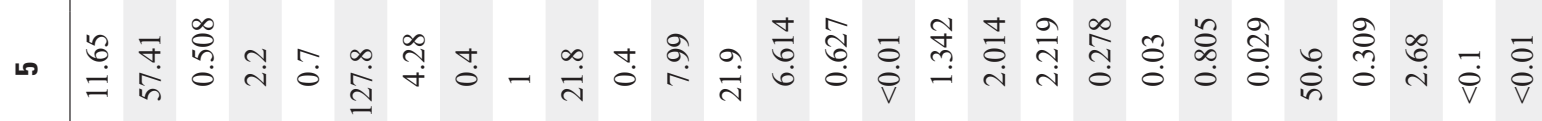

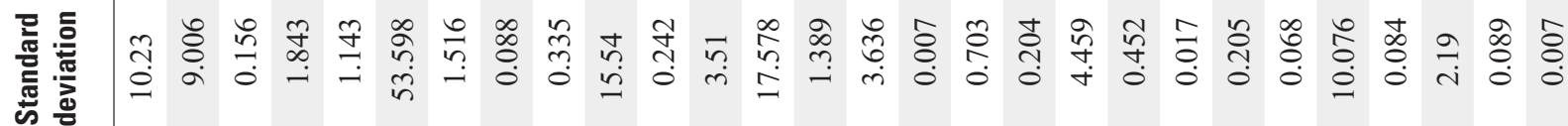

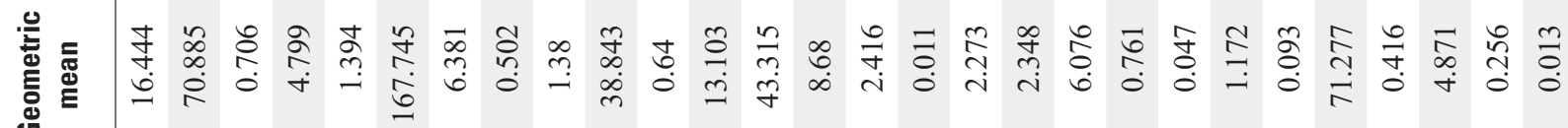

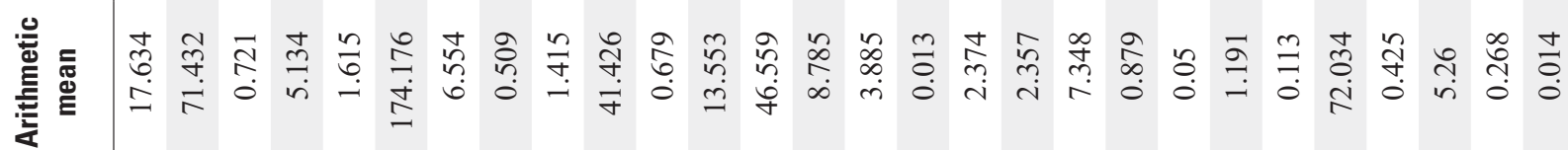

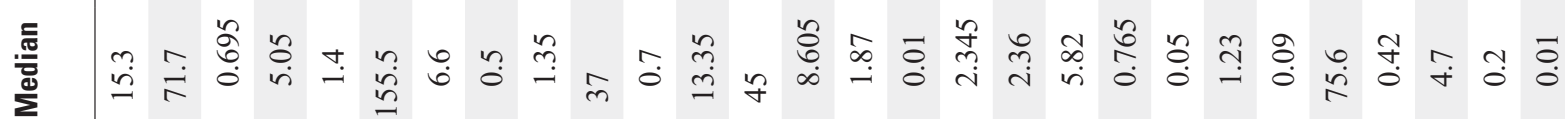

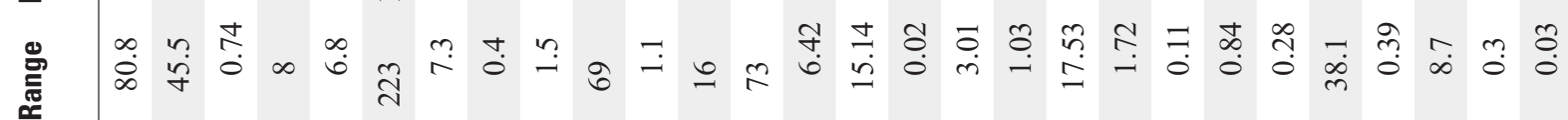

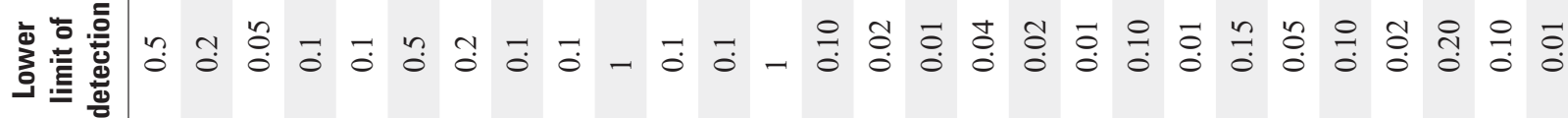

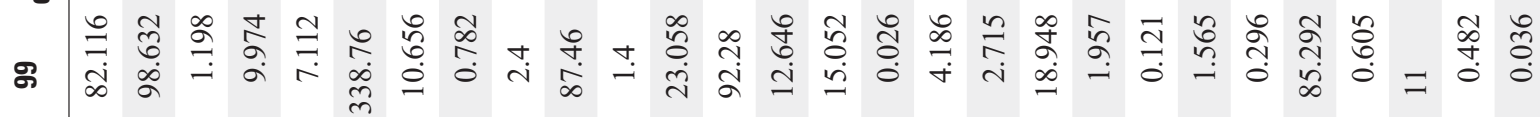

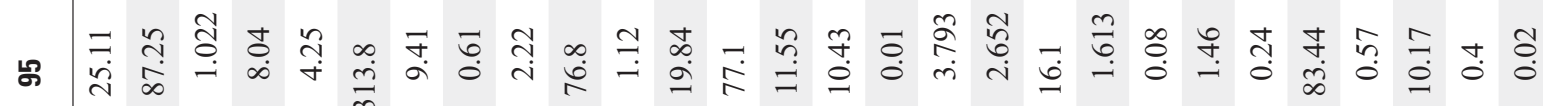


Table 5. Mineralogy of all soil samples collected in 2003, 2004, and 2007, lower Rio Grande valley, Texas.

[Geo_unit, geologic unit as described by Page and others (2005) below soil sample; G, Goliad Formation (Pliocene); L, Lissie Formation (Pleistocene); B, Beaumont Formation (Pleistocene); H, Holocene alluvium; Total_Plag, combined total of all plagioclase minerals present in the sample; Total_Kspar, combined total of all potassium-bearing feldspar minerals present in the sample; Total_Carb, combined total of all carbonate minerals present in the sample (may include some shell fragments)]

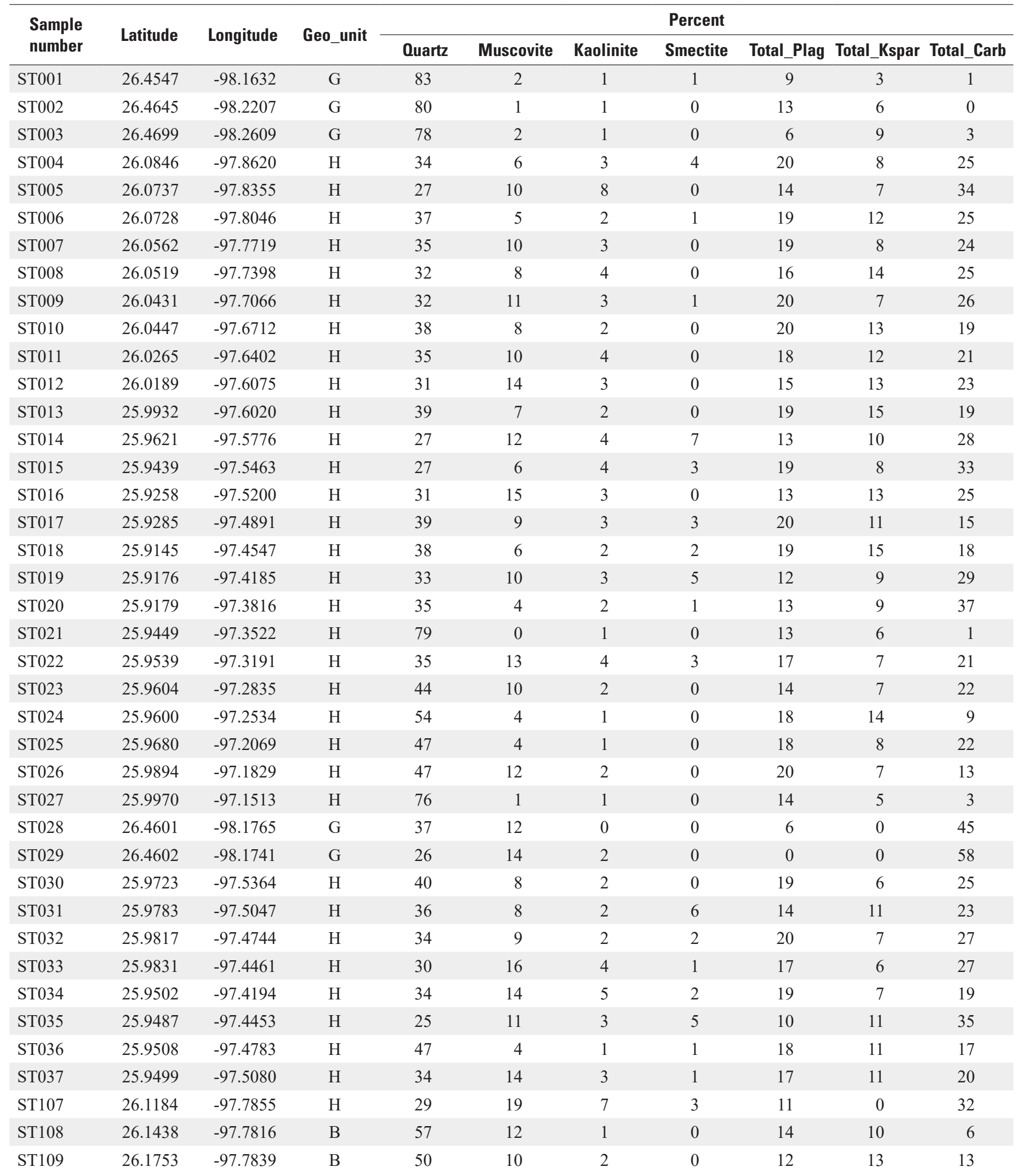


Table 5. Mineralogy of all soil samples collected in 2003, 2004, and 2007, lower Rio Grande valley, Texas. - Continued

[Geo_unit, geologic unit as described by Page and others (2005) below soil sample; G, Goliad Formation (Pliocene); L, Lissie Formation (Pleistocene); B, Beaumont Formation (Pleistocene); H, Holocene alluvium; Total_Plag, combined total of all plagioclase minerals present in the sample; Total_Kspar, combined total of all potassium-bearing feldspar minerals present in the sample; Total_Carb, combined total of all carbonate minerals present in the sample (may include some shell fragments)]

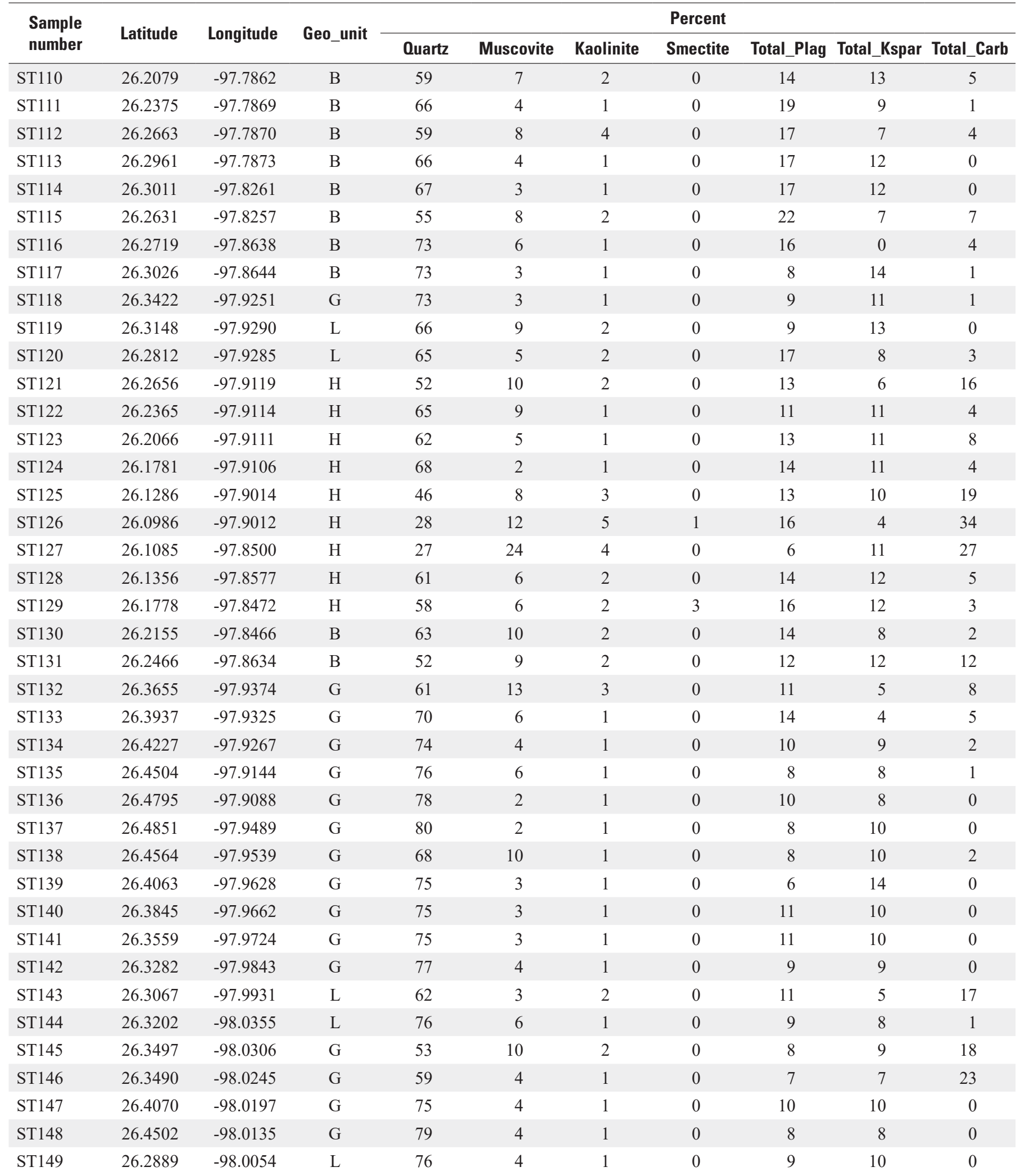


Table 5. Mineralogy of all soil samples collected in 2003, 2004, and 2007, lower Rio Grande valley, Texas.—Continued

[Geo_unit, geologic unit as described by Page and others (2005) below soil sample; G, Goliad Formation (Pliocene); L, Lissie Formation (Pleistocene); B, Beaumont Formation (Pleistocene); H, Holocene alluvium; Total_Plag, combined total of all plagioclase minerals present in the sample; Total_Kspar, combined total of all potassium-bearing feldspar minerals present in the sample; Total Carb, combined total of all carbonate minerals present in the sample (may include some shell fragments)]

\begin{tabular}{|c|c|c|c|c|c|c|c|c|c|c|}
\hline \multirow{2}{*}{$\begin{array}{l}\text { Sample } \\
\text { number }\end{array}$} & \multirow{2}{*}{ Latitude } & \multirow{2}{*}{ Longitude } & \multirow{2}{*}{ Geo_unit } & \multicolumn{7}{|c|}{ Percent } \\
\hline & & & & Quartz & Muscovite & Kaolinite & Smectite & Total_Plag & Total_Kspar & Total_Carb \\
\hline ST150 & 26.4997 & -98.0487 & G & 77 & 5 & 1 & 0 & 11 & 5 & 0 \\
\hline ST152 & 26.4410 & -98.0593 & G & 81 & 2 & 1 & 0 & 10 & 7 & 0 \\
\hline ST153 & 26.4124 & -98.0644 & $\mathrm{G}$ & 76 & 6 & 1 & 0 & 8 & 7 & 2 \\
\hline ST155 & 26.3534 & -98.0751 & $\mathrm{~L}$ & 74 & 5 & 1 & 0 & 10 & 11 & 0 \\
\hline ST156 & 26.3266 & -98.0799 & $\mathrm{~L}$ & 57 & 13 & 1 & 0 & 11 & 10 & 9 \\
\hline ST157 & 26.3617 & -98.1178 & $\mathrm{~L}$ & 71 & 6 & 1 & 0 & 9 & 11 & 2 \\
\hline ST158 & 26.3860 & -98.1138 & G & 73 & 3 & 1 & 0 & 10 & 8 & 4 \\
\hline ST159 & 26.3995 & -98.1385 & G & 76 & 4 & 1 & 0 & 11 & 8 & 0 \\
\hline ST163 & 26.4665 & -98.2377 & G & 78 & 4 & 1 & 0 & 7 & 9 & 1 \\
\hline ST164 & 26.4618 & -98.2048 & $\mathrm{G}$ & 72 & 4 & 1 & 0 & 7 & 10 & 7 \\
\hline ST165 & 26.4560 & -98.1734 & $\mathrm{G}$ & 60 & 5 & 1 & 0 & 5 & 6 & 22 \\
\hline ST166 & 26.4518 & -98.1409 & G & 77 & 4 & 1 & 0 & 11 & 6 & 0 \\
\hline ST167 & 26.5165 & -98.1443 & G & 77 & 1 & 1 & 0 & 7 & 8 & 6 \\
\hline ST168 & 26.5209 & -98.1747 & G & 73 & 5 & 1 & 0 & 7 & 9 & 5 \\
\hline ST169 & 26.5004 & -98.1991 & G & 81 & 3 & 1 & 0 & 7 & 8 & 0 \\
\hline ST170 & 26.4894 & -98.1960 & $\mathrm{G}$ & 80 & 3 & 2 & 0 & 5 & 9 & 1 \\
\hline ST177 & 26.2288 & -97.9602 & $\mathrm{~L}$ & 67 & 7 & 3 & 0 & 13 & 10 & 0 \\
\hline ST178 & 26.1995 & -97.9597 & $\mathrm{~L}$ & 58 & 13 & 4 & 0 & 10 & 11 & 5 \\
\hline ST179 & 26.1704 & -97.9592 & $\mathrm{~L}$ & 54 & 19 & 2 & 0 & 10 & 9 & 5 \\
\hline ST180 & 26.1414 & -97.9576 & $\mathrm{~L}$ & 61 & 9 & 1 & 0 & 7 & 19 & 2 \\
\hline ST181 & 26.1082 & -97.9590 & $\mathrm{H}$ & 32 & 16 & 4 & 0 & 13 & 10 & 25 \\
\hline ST182 & 26.0775 & -97.9584 & $\mathrm{H}$ & 31 & 15 & 2 & 0 & 18 & 7 & 27 \\
\hline ST183 & 26.0855 & -97.9927 & $\mathrm{H}$ & 29 & 10 & 5 & 0 & 14 & 12 & 30 \\
\hline ST184 & 26.0824 & -98.0260 & $\mathrm{H}$ & 27 & 21 & 3 & 1 & 12 & 10 & 27 \\
\hline ST185 & 26.0519 & -98.0636 & $\mathrm{H}$ & 46 & 6 & 2 & 0 & 18 & 10 & 18 \\
\hline ST186 & 26.0764 & -98.0611 & $\mathrm{H}$ & 27 & 16 & 5 & 1 & 12 & 6 & 35 \\
\hline ST187 & 26.1124 & -98.0534 & $\mathrm{H}$ & 28 & 14 & 5 & 0 & 9 & 6 & 37 \\
\hline ST188 & 26.1409 & -98.0472 & $\mathrm{H}$ & 62 & 8 & 2 & 0 & 8 & 11 & 9 \\
\hline ST189 & 26.1702 & -98.0420 & B & 41 & 9 & 2 & 0 & 6 & 8 & 33 \\
\hline
\end{tabular}


Table 5. Mineralogy of all soil samples collected in 2003, 2004, and 2007, lower Rio Grande valley, Texas.-Continued

[Geo_unit, geologic unit as described by Page and others (2005) below soil sample; G, Goliad Formation (Pliocene); L, Lissie Formation (Pleistocene); B, Beaumont Formation (Pleistocene); H, Holocene alluvium; Total_Plag, combined total of all plagioclase minerals present in the sample; Total_Kspar, combined total of all potassium-bearing feldspar minerals present in the sample; Total_Carb, combined total of all carbonate minerals present in the sample (may include some shell fragments)]

\begin{tabular}{|c|c|c|c|c|c|c|c|c|c|c|}
\hline \multirow{2}{*}{$\begin{array}{l}\text { Sample } \\
\text { number }\end{array}$} & \multirow{2}{*}{ Latitude } & \multirow{2}{*}{ Longitude } & \multirow{2}{*}{ Geo_unit } & \multicolumn{7}{|c|}{ Percent } \\
\hline & & & & Quartz & Muscovite & Kaolinite & Smectite & Total_Plag & Total_Kspar & Total_Carb \\
\hline ST190 & 26.1999 & -98.0368 & B & 63 & 6 & 2 & 0 & 13 & 11 & 5 \\
\hline ST192 & 26.2565 & -98.0361 & $\mathrm{~L}$ & 67 & 10 & 2 & 0 & 13 & 6 & 2 \\
\hline ST193 & 26.2856 & -98.0373 & $\mathrm{~L}$ & 63 & 4 & 2 & 0 & 12 & 10 & 8 \\
\hline ST195 & 26.3329 & -98.1230 & $\mathrm{~L}$ & 59 & 7 & 2 & 0 & 10 & 9 & 12 \\
\hline ST196 & 26.3020 & -98.1054 & $\mathrm{~L}$ & 68 & 9 & 2 & 0 & 9 & 9 & 4 \\
\hline ST197 & 26.2844 & -98.0649 & $\mathrm{~L}$ & 51 & 16 & 2 & 0 & 10 & 10 & 12 \\
\hline ST198 & 26.2490 & -98.0747 & B & 57 & 12 & 2 & 0 & 10 & 9 & 10 \\
\hline ST199 & 26.2199 & -98.0793 & $\mathrm{~B}$ & 67 & 5 & 1 & 0 & 10 & 12 & 5 \\
\hline ST203 & 26.0810 & -98.0908 & $\mathrm{H}$ & 25 & 19 & 4 & 1 & 13 & 9 & 30 \\
\hline ST204 & 26.0849 & -98.1279 & $\mathrm{H}$ & 28 & 18 & 3 & 0 & 13 & 5 & 33 \\
\hline ST205 & 26.1185 & -98.1334 & $\mathrm{H}$ & 19 & 28 & 4 & 1 & 8 & 0 & 41 \\
\hline ST206 & 26.1578 & -98.1270 & B & 46 & 14 & 2 & 0 & 9 & 9 & 19 \\
\hline ST207 & 26.1876 & -98.1222 & B & 72 & 3 & 1 & 0 & 12 & 8 & 3 \\
\hline ST208 & 26.2176 & -98.1177 & $\mathrm{~B}$ & 60 & 9 & 4 & 0 & 12 & 9 & 6 \\
\hline ST209 & 26.2533 & -98.1102 & B & 61 & 15 & 3 & 0 & 10 & 11 & 0 \\
\hline ST210 & 26.2823 & -98.1069 & $\mathrm{~L}$ & 55 & 18 & 3 & 0 & 13 & 8 & 3 \\
\hline ST07-006 & 26.4153 & -97.8056 & B & 67 & 4 & 1 & 0 & 13 & 14 & 0 \\
\hline ST07-007 & 26.4080 & -97.8026 & B & 68 & 4 & 1 & 0 & 18 & 10 & 0 \\
\hline ST07-008 & 26.4008 & -97.7945 & $\mathrm{~B}$ & 71 & 2 & 1 & 0 & 11 & 15 & 0 \\
\hline ST07-009 & 26.4083 & -97.7570 & $\mathrm{~B}$ & 49 & 6 & 3 & 3 & 12 & 11 & 16 \\
\hline ST07-010 & 26.4009 & -97.7558 & B & 41 & 8 & 3 & 2 & 13 & 9 & 23 \\
\hline ST07-011 & 26.3864 & -97.7792 & B & 64 & 6 & 1 & 1 & 10 & 18 & 0 \\
\hline ST07-012 & 26.3865 & -97.7704 & $\mathrm{~B}$ & 62 & 4 & 2 & 1 & 18 & 13 & 0 \\
\hline ST07-013 & 26.3862 & -97.7573 & B & 49 & 7 & 2 & 4 & 15 & 12 & 11 \\
\hline ST07-014 & 26.3851 & -97.7476 & $\mathrm{~B}$ & 48 & 10 & 5 & 2 & 13 & 9 & 14 \\
\hline ST07-015 & 26.3862 & -97.7477 & B & 46 & 9 & 3 & 2 & 14 & 10 & 15 \\
\hline ST07-016 & 26.3819 & -97.7356 & $\mathrm{~B}$ & 63 & 5 & 1 & 1 & 14 & 15 & 0 \\
\hline ST07-017 & 26.3719 & -97.7397 & B & 64 & 4 & 2 & 1 & 14 & 15 & 0 \\
\hline ST07-018 & 26.3719 & -97.7454 & B & 70 & 2 & 2 & 1 & 14 & 11 & 0 \\
\hline
\end{tabular}


Table 5. Mineralogy of all soil samples collected in 2003, 2004, and 2007, lower Rio Grande valley, Texas._Continued

[Geo_unit, geologic unit as described by Page and others (2005) below soil sample; G, Goliad Formation (Pliocene); L, Lissie Formation (Pleistocene); B, Beaumont Formation (Pleistocene); H, Holocene alluvium; Total_Plag, combined total of all plagioclase minerals present in the sample; Total_Kspar, combined total of all potassium-bearing feldspar minerals present in the sample; Total Carb, combined total of all carbonate minerals present in the sample (may include some shell fragments)]

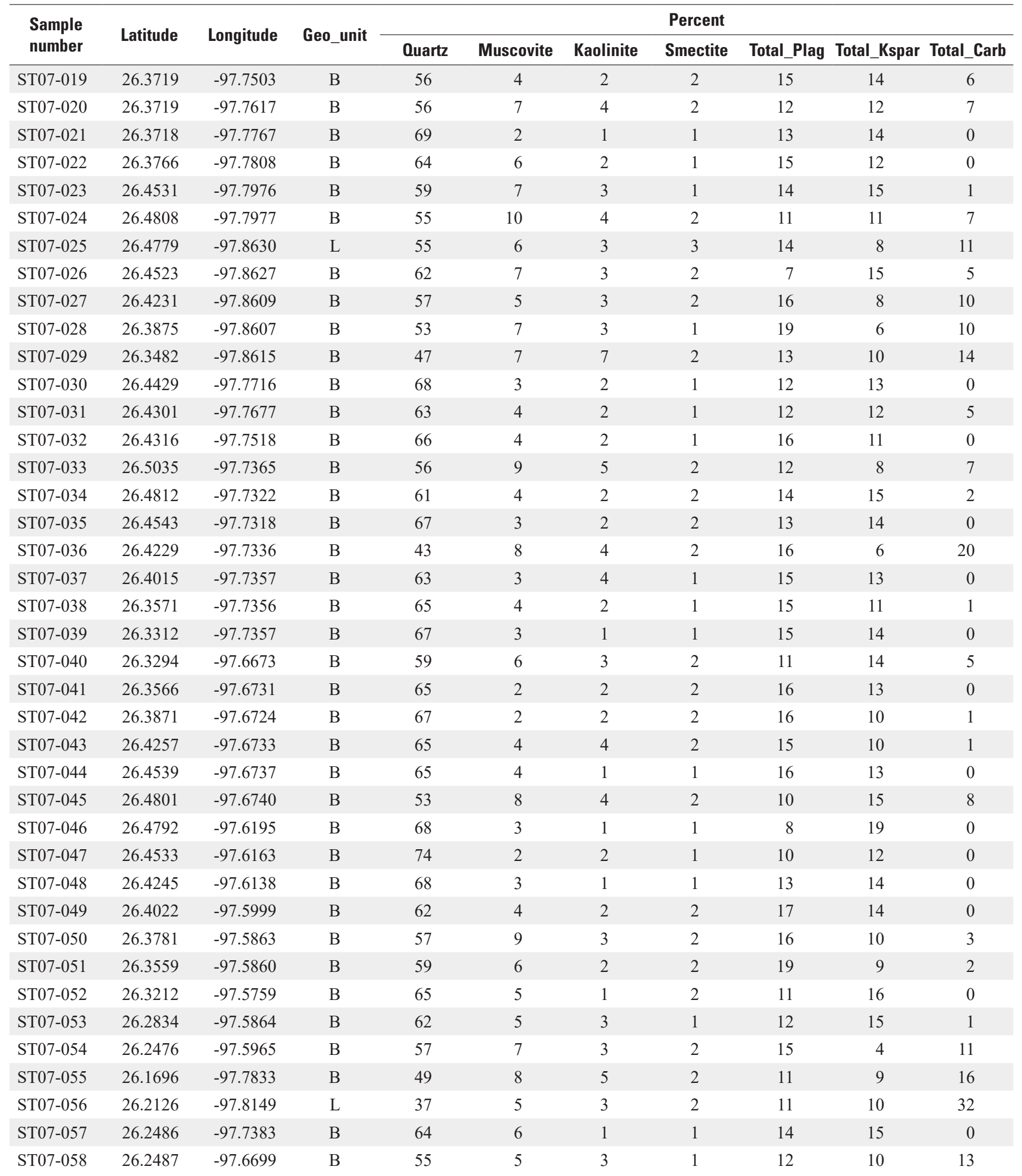


Table 5. Mineralogy of all soil samples collected in 2003, 2004, and 2007, lower Rio Grande valley, Texas.-Continued

[Geo_unit, geologic unit as described by Page and others (2005) below soil sample; G, Goliad Formation (Pliocene); L, Lissie Formation (Pleistocene); B, Beaumont Formation (Pleistocene); H, Holocene alluvium; Total_Plag, combined total of all plagioclase minerals present in the sample; Total_Kspar, combined total of all potassium-bearing feldspar minerals present in the sample; Total Carb, combined total of all carbonate minerals present in the sample (may include some shell fragments)]

\begin{tabular}{|c|c|c|c|c|c|c|c|c|c|c|}
\hline \multirow{2}{*}{$\begin{array}{l}\text { Sample } \\
\text { number }\end{array}$} & \multirow{2}{*}{ Latitude } & \multirow{2}{*}{ Longitude } & \multirow{2}{*}{ Geo_unit } & \multicolumn{7}{|c|}{ Percent } \\
\hline & & & & Quartz & Muscovite & Kaolinite & Smectite & Total_Plag & Total_Kspar & Total_Carb \\
\hline ST07-059 & 26.2768 & -97.6619 & B & 61 & 6 & 3 & 1 & 11 & 17 & 0 \\
\hline ST07-061 & 26.2310 & -97.5573 & $\mathrm{H}$ & 69 & 6 & 3 & 1 & 11 & 9 & 2 \\
\hline ST07-062 & 26.1864 & -97.5646 & $\mathrm{H}$ & 55 & 7 & 3 & 2 & 12 & 12 & 8 \\
\hline ST07-064 & 26.1544 & -97.6114 & $\mathrm{H}$ & 38 & 7 & 4 & 2 & 21 & 8 & 19 \\
\hline ST07-065 & 26.1138 & -97.6478 & $\mathrm{H}$ & 29 & 11 & 6 & 3 & 10 & 17 & 23 \\
\hline ST07-066 & 26.0733 & -97.6916 & $\mathrm{H}$ & 24 & 15 & 7 & 2 & 17 & 9 & 25 \\
\hline ST07-067 & 26.0979 & -97.7194 & $\mathrm{H}$ & 37 & 10 & 5 & 2 & 21 & 10 & 16 \\
\hline ST07-068 & 26.1194 & -97.7373 & $\mathrm{H}$ & 28 & 11 & 8 & 2 & 17 & 9 & 25 \\
\hline
\end{tabular}


Table 6. Summary statistics of mineral content of soils by geologic formation (Page and others, 2005) as determined by $\mathrm{x}$-ray diffraction.

[N, number of samples in the group; N Zero, number of samples with no measurable content; Std. Dev., standard deviation; Min., minimum content measured; Max., maximum content measured]

\begin{tabular}{|c|c|c|c|c|c|c|c|c|c|c|c|}
\hline & & \multirow{2}{*}{$\mathbf{N}$} & \multirow{2}{*}{ N Zero } & \multirow{2}{*}{ Mean } & \multirow{2}{*}{ Std. Dev. } & \multirow{2}{*}{ Min. } & \multicolumn{4}{|c|}{ percentile } & \multirow{2}{*}{ Max } \\
\hline & & & & & & & 25 & 50 & 75 & 90 & \\
\hline \multicolumn{12}{|c|}{ Quartz } \\
\hline Lissie & & 24 & 0 & 62.3 & 8.8 & 37 & 57 & 62.5 & 67 & 75 & 76 \\
\hline Beaumont & & 80 & 0 & 60.4 & 7.6 & 41 & 56 & 62 & 66 & 68.9 & 74 \\
\hline \multicolumn{12}{|c|}{ Muscovite } \\
\hline Goliad & & 43 & 0 & 4.9 & 3.1 & 1 & 3 & 4 & 6 & 10 & 14 \\
\hline Lissie & & 24 & 0 & 9.2 & 4.6 & 3 & 5.25 & 9 & 12.5 & 17 & 19 \\
\hline Beaumont & & 80 & 0 & 6.0 & 3.0 & 2 & 4 & 5.5 & 8 & 10 & 15 \\
\hline Goliad & & 43 & 1 & 1.1 & 0.4 & 0 & 1 & 1 & 1 & 2 & 3 \\
\hline Lissie & & 24 & 0 & 2.0 & 0.9 & 1 & 1 & 2 & 2.75 & 3 & 4 \\
\hline Beaumont & & 80 & 0 & 2.3 & 1.2 & 1 & 1 & 2 & 3 & 4 & 7 \\
\hline Holocene & & 63 & 0 & 3.3 & 1.7 & 1 & 2 & 3 & 4 & 5.6 & 8 \\
\hline & All & 210 & 1 & 2.3 & 1.5 & 0 & 1 & 2 & 3 & 4 & 8 \\
\hline \multicolumn{12}{|c|}{ Smectite } \\
\hline Goliad & & 43 & 42 & 0.0 & 0.2 & 0 & 0 & 0 & 0 & 0 & 1 \\
\hline Lissie & & 24 & 22 & 0.2 & 0.7 & 0 & 0 & 0 & 0 & 1 & 3 \\
\hline Beaumont & & 80 & 25 & 1.1 & 0.9 & 0 & 0 & 1 & 2 & 2 & 4 \\
\hline Holocene & & 63 & 0 & 15.0 & 3.7 & 6 & 12 & 14 & 18 & 20 & 21 \\
\hline & All & 210 & 1 & 12.6 & 3.9 & 0 & 10 & 12 & 15 & 18 & 22 \\
\hline \multicolumn{12}{|c|}{ Potassium feldspar } \\
\hline Goliad & & 43 & 2 & 8.0 & 2.7 & 0 & 7 & 8 & 10 & 10.6 & 14 \\
\hline Lissie & & 24 & 0 & 9.8 & 2.6 & 5 & 8 & 10 & 11 & 12.5 & 19 \\
\hline Beaumont & & 80 & 1 & 11.5 & 3.2 & 0 & 9 & 12 & 14 & 15 & 19 \\
\hline Holocene & & 63 & 3 & 9.1 & 3.5 & 0 & 7 & 9 & 11 & 13 & 17 \\
\hline & All & 210 & 6 & 9.9 & 3.4 & 0 & 8 & 10 & 12 & 14 & 19 \\
\hline \multicolumn{12}{|c|}{ Carbonate } \\
\hline Goliad & & 43 & 17 & 6.2 & 12.0 & 0 & 0 & 1 & 6 & 20.8 & 58 \\
\hline Lissie & & 24 & 4 & 5.9 & 7.2 & 0 & 2 & 3 & 8.75 & 14.5 & 32 \\
\hline Beaumont & & 80 & 32 & 5.0 & 6.6 & 0 & 0 & 2 & 7 & 14.9 & 33 \\
\hline \multirow[t]{2}{*}{ Holocene } & & 63 & 0 & 22.1 & 10.2 & 1 & 17 & 23 & 28 & 35 & 41 \\
\hline & All & 210 & 53 & 10.4 & 11.9 & 0 & 0 & 5 & 19 & 27 & 58 \\
\hline
\end{tabular}


For additional information, contact:

Director, Eastern Mineral and Energy Resources Center U.S. Geological Survey

12201 Sunrise Valley Drive, MS 954

Reston, Virginia 20192

Or visit our website at: https://minerals.usgs.gov/east/

Publishing support provided by the West Trenton Publishing Service Center 
